\title{
THE RECEPTION OF ENGLISH LAW
}

\section{J. E. COTE*}

A new country is faced with a choice in deciding upon a system of law for itself. It can either copy someone else's codified law or it can adopt a system of law which is largely judge-made. If it opts for the latter it cannot afford to spend centuries building up a system of judge-made law. Therefore it must copy the rules of a society which has already developed a sophisticated body of such law. Most of the Commonwealth nations have chosen the latter route and as a result have received English law as their own. The rules and consequences inherent in such a reception are discussed in this article. After a short discussion of the distinction between the Imperial law in force proprio vigore and the English law received in the colony as such, the modes of reception of English law are described. In this respect the differences in reception between settled and conquered colonies are outlined. The parts of English law which have been received and the general rules of applicability as well as the applicability of particular areas of the law are also analyzed. The article concludes with a discussion of repeal, amendment and reform of imported English law by the country receiving such law. An appendix contains an account of the reception of English law in each of the Canadian provinces. The subject of this article is often considered as part of legal history. It should be stressed however that this is not the case, as all the rules described are rules of present-day law and many of them are being applied and expounded continually, particularly in Australia and Canada. This is the author's second article in this area; the first being The Introduction of English Law Into Alberta, (1964) 3 Alta. L. Rev. 262.

\section{INTRODUCTION}

Most of the countries of the Commonwealth and states of the United States of America are known as common-law jurisdictions. This refers to two things. The first is that the bulk of their law is judge-made and not the product of legislation in contrast to jurisdictions with codified law such as France, Germany, Quebec, or Louisiana. The second is that the law is more or less copied from the law of England and is not based on Roman law or any other legal system; the contrast here is with South Africa and Ceylon as well as the areas mentioned above which have codified law.

This double meaning of the term "common-law jurisdiction" is not purely fortuitous either. It has long been remarked that it is easy for a new country to copy the law of a country with a code. The basic principles of the general law of a country like France or Spain are contained in a few volumes whose total bulk is much less than that of the Bible. It is true that the codes themselves do not by any means contain all that one needs to know, ${ }^{1}$ but they tell a great deal, and do themselves contain an intelligible and easily portable framework on which to build. The "common-law" jurisdictions unlike Quebec and Louisiana have not wanted to adopt the idea of a code, let alone copy someone else's code the way a number of new nations in the world have. Nor have they wanted to adopt any uncodified derivative of Roman law, or any European variant of it, in the manner in which South Africa, Ceylon, and (at first) British Guiana did. Yet few of these "common-law" areas had any developed body of laws of their own and those which did

* B.A., LL.B., B.C.L (Oxon.), of the Alberta Bar.

1 The law of delict in France and Quebec, for instance, stems from a very short part of their civil codes and has been developed by writero and judges. 
(such as India) wished for various reasons to adopt a largely Western system of law. The natural thing for such a new country to do was to copy English law.

If one admires the methods of French law, one may avoid simply copying French law by using the French method of compiling one's own code of law. But if one admires English law, one cannot afford to spend nine centuries painfully building up a system of judge-made law. ${ }^{2}$ Hence the need to copy the very rules of English law itself. Indeed, a number of jurisdictions have deliberately done just that. To take two examples British Columbia and Nigeria by legislative act declared that the law of England as it existed on a certain date would henceforth be the law of the new country (except as amended by local legislation).

This solution was not so artificial or arbitrary as all that for the great bulk of these territories began as British colonies, and British constitutional law has long had very particular rules as to when and how English law becomes the law of a colony. Some colonies never passed any statute of their own introducing English law and so these British constitutional rules were the basis for an automatic copying of English law. Even those colonies which deliberately chose to accept English law did not ignore the traditions of British constitutional law, and their copying was inevitably influenced by this British constitutional law. The purpose of this work is to investigate these influences, and the rules which resulted.

India, Pakistan, and the United States of America fall largely outside the compass of this work for two reasons. First, their legal histories are quite different from those of other members or ex-members of the British Empire and Commonwealth. Pre-Partition India was a complicated mosaic of states of varying degrees of independence and with a bewildering array of legal systems, and where English law had been introduced, this had largely been sub silentio, on the theory that its rules were an expression of natural equity and justice. The United States of America is also a large, though less intricate, legal mosaic and its very separation from the Empire and subsequent legal development as an independent country, have largely colored its use of English law. Furthermore, valuable research into the legal history of the American adoption of English law has only begun in recent years and is still very incomplete. In the second place, both the United States and the Indian subcontinent have produced such enormous mountains of law in all forms that even the aspect of their law here discussed is more than one person can hope to master. Therefore, this work is largely confined to the law of the other common-law jurisdictions.

Aside from the "common-law" jurisdictions, a certain amount of English law was introduced into the other jurisdictions of the Commonwealth, such as South Africa or Quebec, and we shall consider the rules governing this introduction as well.

The rules which we will examine (like so many common-law rules) mirror the history of their growth, and some are quite unintelligible in the absence of an acquaintance with the history of the British Empire. Then again, one cannot fully understand the picture today in any part of the Commonwealth without reference to the history of the individual

2 One could create a codification of English common law, but no new country has started this way, though India and some American states have done a good deal later to codify the law. 
territory in question and the manner in which it first became a part of the Empire. Many of the terms and notions used in the rules which we will examine are terms and notions from times long past and the events we must recall are almost all anterior to 1880 and many to 1800 . It is probably for this reason that discussions of the present topic are sometimes indexed or classified under the heading "legal history". This is not a work of legal history however; all the rules discussed are rules of present-day law, and many of them are being applied and expounded continually, particularly in Australia and Canada.

The title of the work may appear a trifle surprising. Instead of "Reception," one could just as well have referred to the "Adoption" of English law, or its "Migration"3 or "Introduction." A similar process took place at the end of the Middle Ages when European countries chose to adopt large segments of Roman law, and as this process is always referred to as the Reception of Roman Law, it seems useful to acquiesce in this settled usage and to speak of the Reception of English Law. ${ }^{4}$

The reader will soon notice that this work suffers from want of a convenient term to refer to the territory receiving English law. For want of anything better, the term "colony" will be used. It goes without saying that it is simply a relic from the age when the rules to be described were being formed and that it implies no inferior status. The vast majority of the territories which have received English law are now self-governing and independent, but as the reception of English law has nothing to do with legislative powers or independence, use of the term "colony" here seems comparatively harmless.

\section{A. An Overview of the General Rules of Reception}

We can best introduce the rules governing the reception of English law, and what parts of English law are in force in various common-law countries, by a brief description of the principal rules. This will bring to the fore and render intelligible some of the cardinal distinctions which might otherwise be obscured in the historical section which follows and in the detailed exposition of the rules which comprises the bulk of this work.

\section{(1) A Preliminary Distinction}

The first and most important distinction ${ }^{5}$ to be borne in mind is that between:

1. Imperial Law in force proprio vigore, and

2. English law received in the colony as such,

for it is really only the second with which this work is concerned. We are concerned with what happens when an English common-law rule or an English statute is copied by the law of a colony because it was part of the law of England.

Imperial law in force proprio vigore, i.e. by its own force, is very different. It consists of statutes which were passed by the Imperial Parliament at Westminster and intended by that Parliament to be in force in the colony at a time when it was part of the Empire and so

\footnotetext{
3 See the symposium in (1960) 76 LQ.R. at 39.77.

- As does the Harvard Legal Bibliography.

5 MacRae, Constitutional Law 63 mimeographed, no date; Keith, 1 Responsible Government in the Dominions 342 (2d ed. 1928); Ridges' Constitutional Law 478 (8th ed. 1950); R. v. McCarthy (1873) 4 Aust. Jur. R. 155 at 156 (Vict.).

- Purists will note that the word "Empire" is not used here in any very strict sense.
} 
subject to the Imperial Parliament. If the Merchant Shipping Acts are expressed by the Imperial Parliament to be in force in all Her Majesty's Dominions then they are part of the law of New Zealand because the Imperial Parliament has said so, and the Imperial Parliament at the time these Acts were passed had an unfettered right to pass law for New Zealand. They are not law in New Zealand because New Zealand has adopted English law; indeed, they would be law in New Zealand even if New Zealand had not adopted English law. Furthermore, they are not law in New Zealand (or any colony) because they are law in England; they would be in force in New Zealand even if they were not in force in England. Many Imperial statutes are still in force proprio vigore in some colony because the Imperial Parliament passed them for that colony alone: it is therefore perfectly clear that the introduction of English law is not in question at all for such statutes are not English law in any sense.

Familiar examples of Imperial law in force proprio vigore are the constitutional acts creating the Canadian and Australian federations. They are not English law, for they never have formed any part of the law of England. Nor do they depend upon any form of reception of English law, for the British North America Acts are in force in the Province of Quebec though it has not introduced the greater part of English law at all.

This distinction between reception of English law, and Imperial law in force proprio vigore seems simple enough when stated so baldly, but it is easy to forget when one is discussing the reception of statutes as part of English law. It is quite common to hear the contention that such-andsuch an English statute was not received as part of the English law when a certain colony received English law because the statute in question was plainly intended by its express terms to have effect only in England, Wales, and Berwick-upon-Tweed and not overseas in the colonies. ${ }^{7}$ But that is only to say the statute is not in force in the colony proprio vigore. For reception of English law that is irrelevant; reception of English law requires only that the statute have been in force in England. ${ }^{8}$ It is some further rule of the colony's law (whether common law or statutory) which then copies the English law in the new country. One may say that a gigantic incorporation by reference of English law into the colony's law is effected.

A simple example will make this clear. Suppose that in 1800 the Parliament ${ }^{9}$ at Westminster passed an Act expressly stated to be in force in England only and not in force in the colonies. Further, suppose that in 1840 the legislature of a colony passed an Act declaring the previous Act of 1800 to be in force in the colony. Can there be any doubt that it would be thereby made part of the colony's law? What difference would it make then, if instead of naming all the English Acts separately, the colonial legislature had simply declared that all English statutes not yet repealed were in force in the colony? Would the 1800 Act not be included

\footnotetext{
The Privy Council seemed to come very close to falling into this trap in Huggard Assets Ltd. v. A. G. Alta. [1953] A.C. 420 at $441-2 ; 8$ W.W.R. (N.S.) 561 at 569-70, a trap which the Supreme Court of Canada below had avoided. There are a few words in the Privy Council's advice ("meant to have merely a local operation") which could be taken as an example of this error too in A.G. v. Stewart (1817) 2 Mer. 143 at 161; 35 E.R. 895 at 900. So many General Motors Acceptance v. Perozni (1965) 52 W.W.R. 32 at 44-5 (Alta. D.C.); Cf. Johnson v. $\boldsymbol{R}$. [1904] A.C. 817 (P.C.); $R$. v. Maloney (1836) Legge 74 (N.S.W.) may contain the mistake too, but there appears to be some doubt as to the accuracy of the report.

- Miller-Morse Hardware Co. v. Smart [1917] 3 W.W.R 1113 at 1117 (Sask. C.A.).

- Meaning of course, the Parliament of the United Kingdom of Great Britain and Ireland legislating for England alone.
} 
in these? And if the 1800 Act were suitable to be used in the colony, what difference would it make if the 1840 Act introduced all suitable English Acts? The fact that the 1800 Act was on its face not intended to have force outside England would be irrelevant. ${ }^{10}$

This fundamental distinction was expounded as early as 1822 when Forbes C.J. held that an English Act could be in force in Newfoundland even though it was in terms expressed not to be in force outside England: "The laws of England, as such, are the laws of Newfoundland. . . ."11 Similarly, in $R$. v. Roblin ${ }^{12}$ Robinson C.J. noted that the English Act 26 Geo. 2 c. 33 expressly provided that it was not to apply to overseas matters and so was not intended to be in force in the colonies; yet it could nevertheless be in force in Upper Canada, because a local statute had later introduced the "laws of England as the rule for decision" of such matters and that clearly meant English statutes as well as the common law.

The same judge had even earlier resolved a still more difficult problem, in Bank of Upper Canada v. Bethune. ${ }^{13}$ The Imperial Parliament had passed 6 Geo. 1 (one of the Bubble Acts) for the entire Empire and later repealed it by $6 \mathrm{Geo} .4 \mathrm{c}$. 91 . In the interval, however, the Upper Canada statute, and an Imperial statute, had introduced English law into the colony. Nevertheless, the judge held that the Act of 6 Geo. 1 was repealed everywhere. The introduction of English law was intended to import only statutes which were purely English, and was not intended to cover statutes in force all over the Empire and so needing no introduction. That being so, the Act of 6 Geo. 1 was in force proprio vigore only, and when it was repealed later, its sole claim to be law disappeared.

Yet another corollary flows from this important distinction between Imperial law in force proprio vigore and reception of English law: only the former raises questions of constitutional power and independence of the new country. Of course most of the Commonwealth is now selfgoverning and consequently can pass what legislation it wants, can repeal Imperial Acts, and is also not bound by new Imperial Acts. All that is irrelevant to the reception of English law, however, for whether to adopt English law on some point or not for domestic use is a matter within the power of any local legislature, even that of a colony which is not completely self-governing. In the same way, a colony may repeal part or all of the English law in force but it cannot disembarrass itself of Imperial Acts in force proprio vigore unless it is self governing. Thus the powers granted by the Statute of Westminster, $1931,{ }^{14}$ concern only Acts in force proprio vigore. ${ }^{15}$

(2) Imperial Acts in Force Proprio Vigore

Although the present work is not primarily concerned with Imperial legislation which is in force proprio vigore, a brief sketch of some of the

10 It would be otherwise of course, if the Parliament at Westminster meant to forbid the colonies to use this Act but that would be most extraordinary, in fact it probably has never been done. Rather Parliament has intended in restricting Acts to England and Wales (or to Great Britain) only to refrain from saying anything at all about colonial or Dominion law.

"Yonge v. Blaikie (1822) 1 Nnd. L.R. 276 at 283.

12 (1862) 21 U.C.Q.B. 352 at 354-55. Another case is Miller-Morse Hardware Ltd. v. Smart, supra, n. 8. Also cf. Allott, Essays in African Law 9 (1960) and Park, Sources of Nigerian Law 25 (1963); Young v. Abina (1940) 6 W.A.C.A. 180; Lawal v. Younan [1961] 1 All Nigeria L.R. 245 at 255-56.

i. (1833) 4 U.C.Q.B. 165 at $170-71$.

14 (Imp.) 22 Geo. 5, c. 4.

is Hoffman, South African Law of Evidence 6 (1963); Keith, supra. n. 5. 
rules governing such legislation may be of some interest. ${ }^{16}$ Because the Imperial Parliament possessed the ultimate and final power of lawmaking throughout the Empire, it was obvious that local colonial assemblies could not gainsay its laws. There was some tendency ${ }^{17}$ to go further than this, however, and to say that no English law could be contradicted by a local legislature. The matter came to a head in the early 1860's, when a judge in South Australia began to hold many local statutes invalid on the ground that they conflicted with the English common law. In other words, he stepped over the bounds of protection of Imperial legislation in force proprio vigore, to protection of English law received into the colony. This was as intolerable as it was unnecessary, and the Imperial ${ }^{18}$ Parliament was forced to pass the Colonial Laws Validity Act in 1865. Section 2 made void any local colonial legislation which was "repugnant to the provisions of any Act of [the Imperial] Parliament extending to the colony" or subsidiary legislation made thereunder, ${ }^{19}$ thus confirming the rule which had always been understood to exist. But section 3 confined this rule to Imperial legislation, providing that colonial law was not to be void because of "repugnancy to the law of England".20

The distinction intended between Imperial Acts in force proprio vigore and English law received was recognized in the leading case of Phillips v. Eyre ${ }^{21}$ by Willes J. who refused to hold a colonial Act of indemnity void because it was contrary to the general principles of English law. ${ }^{22}$

But even the proviso that local laws are not to contradict Imperial statutes in force proprio vigore, has been removed as to self-governing parts of the Commonwealth by the Statute of Westminster, $1931^{23}$ which (with saving for the British North America Acts) allows the selfgoverning countries to repeal or amend Imperial statutes in force proprio vigore, and forbids such future Imperial legislation with respect to these countries without the assent of their own local legislatures. Of course this does not of itself repeal Imperial legislation in force proprio vigore: it only permits the local legislature to do so..24

One matter which has received little attention is whether Imperial statutes passed to deal with all the colonies apply to colonies acquired after the passage of the Acts in question (whether by conquest or by settlement). There is some authority which suggests that they do; ${ }^{25}$ after all, the contrary result would be most anomalous.

16 The analogous study of the statutes in force under the old law in conquered colonies is also interesting: see Symes v. Cuvillier (1880) 5 App. Cas. 138, (P.C.) and Mignault, Droit Civil Canadien 20.23 (1895).

17 This view was not groundless: see Keith, supra, n. 5 at 339-40; Roberts-Wray, Commonwealth and Colonial Law 396-97 (1966).

1828 \& 29 Vict, c. 63. The history and effect of this Act are well reviewed in Roberts-Wray, supre, n. 17, and in Castles, The Reception and Status of English Law in Australia (1963) 2 Adel. L. Rev, 1 at 22-28.

19 This latter provision throws doubt on Reynolds v. Vaughan (1872) 1 B.C.R. 3 at 4 which held that though an Imperial Act was in force proprio vigore, even so Orders in Council made under it were not.

20 And to make assurance doubtly sure, all South Australian statutes were confirmed by section 7!

21 (1870) 40 LJ.Q.B. 28 at 36; L.R. 6 Q.B. 1 at $21-22$.

22 Indeed, counsel for the plaintiff must have realized this was so, for they also urged that it was repugnant to (Imp.) $11 \& 12$ Wm. 3, c. 12 and (Imp.) 42 Geo. 3, c. 85.

23 (Imp.) 22 Geo. 5, c. 4.

$24 R$. v. Innes [1933] O.R. 169 at 171 (C.A.). What is such a repeal may itself create a problem. On local repeal and consolidation of Imperial Acts see $R$. v. Mason (1904) 6 W.A.L.R. 134 (C.A.). But the Statute of Westminster allows repeal of Imperial law by a Dominion Order in Council duly authorized, even if the empowering statute was passed before 1931: Co.Operative Committee v. A.C. [1947] A.C. 87 at 106-07 (P.C.). Clark, A Summary of Colonial Law 15 (1834); R. v. DeBanoy (1968) 2 D.L.R. (3d) 424.

${ }^{23}$ Cf. R. v. Jameson (1896) 65 L.J.M.C. 218 at 225. 
The distinction reiterated above, between Imperial Acts in force proprio vigore, and English law in force only by local reception is clear in theory but sometimes difficult to apply in practice. After all, the same Parliament at Westminster has legislated for England, then Great Britain, then the United Kingdom, and at the same time for the Empire and Commonwealth. If it passed an Act which, let us say, made it an offence to forge a bill of lading, was that meant to be law for England, for the United Kingdom, or for the whole Commonwealth? One cannot always tell, especially when older statutes are in question. The courts generally assume that statutes were intended by Parliament to be domestic in operation only, and not to affect the colonies. Lord Mansfield said in 1769 that: 26

No Act of Parliament made after a colony is planted, is construed to extend to it, without express words showing the intention of the legislature 'that it should'.

In Upper Canada in 1864, Vankoughnet C. was more emphatic:27

While I admit the power of the Imperial Legislature to apply by express words their enactments to this country, I will never admit that, without express words, they do apply, or are intended to so apply. . . . We are entrusted with all the work of local selfgovernment. . . Every year witnesses in the legislature of England some change in the law. The statute containing it does not say in express words that it shall not extend to the colonies, and is confined to Great Britain; but surely, notwithstanding that omission, no one would for a moment suppose it in force here.

In recent years, the Privy Council has confirmed this rule, saying: ${ }^{28}$

An Act of the Imperial Parliament today, unless it provides otherwise, applies to the whole of the United Kingdom and to nothing outside the United Kingdom, not even to the Channel Islands or the Isle of Man, let alone to a remote overseas colony or possession.

They went on to say that in the 17th Century there was no such rule, and that one simply had to gather the extent of such an Act from its subject-matter and what it enacted. It has been suggested ${ }^{29}$ that where an Imperial Act applies to the colonies later Imperial Acts modifying the first one are also intended to apply to the colonies.

\section{(3) The Modes of Reception of English Law}

Returning now from Imperial Acts to laws which are received in the colony simply because they are the law of England we must draw a further distinction. The mode in which English law is deemed to be received in a new country depends on the manner in which the territory became a British colony. If it was a largely uninhabited and unorganized territory settled by British subjects the courts will apply a common-law rule deeming these settlers to have brought English law with them on the foundation of the colony. As a general rule, one may say that the law of such a country is taken to be the law which existed in England at the time the colony was settled (save for any English law plainly unsuitable) subject of course to later amendments passed in or for the colony. Prime examples of such territories were the Australian colonies, and some of the older West Indian colonies. ${ }^{30}$ We will examine

2n $\boldsymbol{K}$. v. Vaughan (1769) 4 Burr. 2494 at 2500; 98 E.R. 308 at 311 (K.B.); accord Dwarris, A General Treatise on Statutes 527 (2d ed. 1848).

$\therefore$ Penley v. Beacon Assurance Co. (1864) 10 Grant Ch. 422 at $428-29$.

2* Huggard Assets Ltd. v. A.G. Alta., supra, n. 7.

29 Dwarris, supra, n. 26 at 527.

so One must use the past tense with respect to the Australian states, for there statutory rules have intruded at one time or another. 
at some length the significance of the exclusion of unsuitable English law in later chapters.

All other territories which could not be put within this category of "settled colonies" were called conquered colonies. Obvious examples of conquered colonies were the Cape Colony, captured from the Dutch; and Quebec, captured from the French. This category was extended to areas which had been peacefully ceded whether by some other colonial power or as in the case of Malta by the inhabitants. Writers sometimes speak of "conquered or ceded colonies", but as the rules appear not to distinguish between them, it is just as easy to lump them both together as conquered colonies. Also to be found in this category of conquered colonies are territories which had a civilized government and system of laws at the time of British settlement, notably the Indian subcontinent. Here of course the term "conquered colony" is legally accurate and useful, though it may be historically most misleading.

It was natural that settled colonies should receive English law, for they had none other, and the British settlers would expect their own laws to govern them as they had at home. Large as the Scots have bulked in the history of the British Empire, no one has ever doubted that it was purely English law which was introduced into such colonies. ${ }^{31}$ This is true even of Nova Scotia, though the only way to justify the theory that it was a settled colony was to point to a shadowy grant from James I when he was James VI of Scotland! None of these considerations applied to so-called "conquered colonies" however. In these territories much more harm than good would have been done by a wholesale introduction of English law for the existing laws were familiar and tried and tested. Unfamiliar English law would have worked a grave injustice to the inhabitants, and likely as not have proved unworkable to boot. ${ }^{32}$ Therefore the rule has been to leave as much of the existing law in force in such areas as possible. British courts will assume it is left in force until it is specifically changed, with the exception of constitutional laws or particularly barbaric laws.

The rules given above for the laws of conquered and settled colonies are common-law rules, developed at a relatively early date by English and then colonial courts. Comparatively few territories are today governed solely by these rules however. In the first place, in most settled colonies there has intruded a statute, sometimes local and sometimes Imperial, confirming the reception of English law, and defining exactly the date as of which English law has been received. Sometimes the date chosen is that of the original foundation of the colony, but often it is a good deal later in time. ${ }^{33}$ And in the second place, few conquered colonies have been able to resist all infusions of English law and usually a combination of custom and local statute have confirmed this. Quebec, for instance, received English criminal law almost from the beginning and English law as to negotiable instruments soon after. South African territories introduced English mercantile and evidentiary law some time ago. Indeed, British Guiana in 1917 replaced Roman-Dutch law entirely with English law. These various local statutes on the reception of

\footnotetext{
31 Hayduk v. Waterton (1968) 64 W.W.R. 641 at 653, $656-57$ (S.C.C.).

s2 The experience in Quebec after the Proclamation of 1763 introducing English law bears this out: see Burt. The Old Province of Quebec 89, 95, 159 (1933); Neatby, The Administration of Justice Under the Quebec Act 3-4 (1937); and Kennedy, Documents of the Canadian Constitution 1759.1915 44, 56 (1918).

.4. Some of the dates chosen in the eastern parts of Malaysia are as late as 1951.
} 
English law are usually interpreted in the same manner as the commonlaw rules on the subject, and so may be studied together with the common-law rules.

The imaginative reader may already have concluded that such a wholesale reception of English law into a new country is a useful shortcut in the early years, but may prove to be a great bother in the end. Local statutes and common-law rules are easy to ascertain but a dusty collection of obscure and ancient English statutes long since forgotten in the mother country, is not. A few pioneering jurisdictions have tidied up this mess by reprinting or re-enacting the old English Acts which are still of use, and so putting them in a convenient and accessible form. Often the other ones have been repealed. Our detailed examination in the chapters to follow will close with an account of these much-needed reforms.

\section{THE MODES OF RECEPTION OF ENGLISH LAW}

In the Introduction we briefly examined the different types of colony recognized at common law and the kind of law in force in each. We will now consider these matters in more detail and then pass on to other ways in which English law may be received.

\section{A. The Distinction Between Settled and Conquered Colonies ${ }^{34}$}

There is little point in adducing cases in support of the distinction between these two types of colony and the resulting difference in law received for almost every case on the subject of reception recites this distinction. Among the classic authorities are Campbell v. Hall, ${ }^{35}$ a Memorandum ${ }^{36}$ of a Privy Council decision in 1722 and the early decision of Blankard v. Galdy. ${ }^{37}$ The Memorandum contrasts the case where "there be a new and uninhabited country found out by English subjects" with the situation where "the King of England conquers a country", and speaks of his "saving the lives of the people conquered." This only describes the simplest and most clear-cut cases. One could have little doubt that the Falkland Islands were a settled colony for there was no one living there when British subjects first made their homes there. ${ }^{38}$ Newfoundland and some of the Caribbean Islands had a few aborigines but they died out in the early years and left no cultural traces whatever, so these islands too may be classified as settled colonies. The aborigines of Australia have survived, but they were few in number and possessed little in the way of laws and government, so there again the country was for legal purposes a tabula rasa. An extreme example of this reasoning is afforded by the colony of Gibraltar, which was very forcibly wrested from its Spanish owners, who then confirmed the conquest by treaty. But all the original inhabitants then departed, and it appears to have been treated as a settled colony until legislation on the subject rendered the question academic.

The aborigines of the New World were always disregarded for these

\footnotetext{
34 For present purposes, there is no point in distinguishing between conquered and ceded colonies. $C f$. n. 42 , infra.

35177420 St. Tr. 230 (K.B.), especially at 320, 329; 1 Cowp. 204 at 208-09; 98 E.R. 1045 at 1047-49; Lofft. 655, 98 E.R. 848.

362 Peere Wms. 75, 24 E.R. 646; further details of this decision are lost: Smith, Appeals to the Privy Council from the American Plantations 482-3 (1950).

${ }^{37}$ (1693) 4 Mod. 222, 87 E.R. 359; 2 Salk. 411, 91 E.R. 356-57; Holt K.B. 341,90 E.R. 1089; Comb. 228, 90 E.R. 445.

34 Pace the Argentine claims by virtue of prior discovery.
} 
purposes also, no matter how numerous they might be. ${ }^{39}$ Presumably the assumption was that their laws and customs were either too unfamiliar, or too primitive, to justify compelling British subjects to obey them. Given the fact that the British courts did not originally intend to regulate disputes among the North American Indians this was probably the only decision which could have been reached in the circumstances. Some of the early writers ${ }^{40}$ therefore suggested as the test, whether or not the territory had been formerly governed by a Christian monarch. If it had, it was a conquered colony; if it had not, its "heathen" laws were to be disregarded and it was to be treated as a settled colony. This was a satisfactory test in the Seventeenth Century but the courts expressly disapproved of it more than once in the next century. ${ }^{41}$ But cession by less civilized aborigines has been held in one case at least to prevent a colony from being considered a settled colony. ${ }^{42}$

This was the result of the spread of the British settlements in the Far East, and in particular, those on the Indian subcontinent. They grew up in the midst of a very old well-developed civilization whose culture, laws, and most significantly, whose commerce, were as developed as those of European countries. More important still, these were well-populated countries and the English settlers were not numerous, especially in the early years. Therefore at first the English settlers formed only trading communities. In time, they acquired extraterritorial rights and finally established courts with jurisdiction over English traders, then other Europeans, and in time, even over disputes between the local inhabitants. In view of these conditions, it was inconceivable that the local laws could be ignored to any great degree. Yet to this point the only justification for retention of the existing laws had been conquest from another European ruler and in most Asiatic cases that was by no means the history of the settlement. We may observe the Privy Council wrestling with the problem in the leading case of Advocate-General of Bengal v. Ranee Surnomoye Dossee in 1863:43

Where Englishmen establish themselves in an uninhabited or barbarous country, they carry with them not only the laws, but the sovereignty of their own State; and those who live amongst them and become members of their community become also partakers of, and subject to the same laws.

But this was not the nature of the first settlement made in India-it was a settlement made by a few foreigners for the purpose of trade in a very populous and highly civilized country, under the government of a powerful Mahomedan ruler, with whose sovereignty the English Crown never attempted nor pretended to interfere for some centuries afterwards.

If the settlement had been made in a Christian country of Europe, the settlers would have become subject to the laws of the country in which they settled. It is true that in India they retained their own laws for their own government within the Factories, which they were permitted by the ruling powers of India to establish. . . .

The laws and usages of Eastern countries where Christianity does not prevail are so at variance with all the principles, feelings, and habits of European Christians that they have usually been allowed by the indulgence or weakness of the Potentates of those countries to retain the use of their own laws, and their Factories have for many purposes been treated as part of the territory of the Sovereign from whose dominions they came. But the permission to use their own laws by European settlers does not extend those laws to Natives within the same limits, who remain to all intents and

\footnotetext{
39 Stwry, Commentaries on the Constitution of the United States 106-07 (5th ed. 1891).

10 Calvin's Case (1609) 7 Co. Rep. la at 17b; 77 E.R. 377 at 398.

"Campbell v. Hall (1774) 1 Cowp. 204 at 209, 98 E.R. 1045 at 1047 (K.B.).

12. This was the case of New Zealand. See Roberts-Wray, Commonwealth and Colonial Law 104-07 (1966) and authorities cited there.

432 Moo. P.C. (N.S.) 22 at 59-61; 15 E.R. 811 at 824-25, per Lord Kingsdown.
} 
purposes subjects of their own Sovereign, and to whom European laws and usages are as little suited as the laws of the Mahometans and Hindoos are suited to Europeans. ...

But, if the English laws were not applicable to Hindoos on the first settlement of the country, how could the subsequent acquisition of the rights of sovereignty by the English Crown make any alteration?

This passage thus gives a justification of the compromise which was reached in a number of the Far Eastern territories, especially in the Indian subcontinent. Europeans were governed ultimately by English law, while the local inhabitants were governed by their own religious and customary laws, except in certain matters of commercial practice where English law eventually carried the day. This was an eminently practical solution, but it owes nothing to the old theory of settled and conquered colonies, and if anything is quite subversive of that theory.

An earlier attempt to reconcile the Indian experience with this theory yielded results which for our present inquiry are much more valuable: 44

The general rules, as to the law of Countries newly settled, by British subjects, or acquired by the British Crown, are not fully adverted to by the learned Judges whose opinions are in evidence before me, and not, I conceive, accurately applied by them to the case of our Indian settlements. It is true, as remarked by Sir Anthony Buller, that if a new Country is discovered and settled by British subjects, they carry with them the English law, but with this modification, unnoticed by the learned Judge, that is, so far only as that law is applicable to their local circumstances.

He went on to say that for these purposes India was not a newlydiscovered country, but one acquired by cession or conquest. Such countries at common law keep their existing law, yet this settlement did not really fall within that latter rule, or the principles on which either rule was founded. He continued:

I apprehend the true general distinction to be, in effect, between Countries in which there are not, and Countries in which there are, at the time of their acquisition, any existing civil institutions and laws, it being, in the first of those cases, matter of necessity that the British settlers should use their native laws, as having no others to resort to; whereas, in the other case, there is an established lex loci, which it might be highly inconvenient to abrogate; and, therefore, it remains till changed by the deliberate wisdom of the new legislative power.

He went on to say that the distinction between newly-founded colonies and others had grown up because in practice it paralleled that between colonies with an existing lex loci, and those without, for the countries conquered usually had had civilized Christian rulers and so fairly similar institutions to English ones. India (as we noted above) did not fit into this mold and an exception had to be made for her. ${ }^{45}$

In the years since that time, the theory has not really advanced. In other areas such as Malaysia where similar problems were encountered, the common law was not resorted to, and various ad hoc legislative solutions were used on the spot. Sometimes the nucleus of the settlement was an uninhabited area, sometimes a small settlement in which the British were given complete powers of government by the local rulers. In such areas, letters patent appointing governors or judges usually provided for the use of English law, or in any event the vague words

4f Freeman v. Fairlie (1828) 1 Moo. Ind. App. 305 at 324-25; 18 E.R. 117 at 128 (P.C.). The speech is that of the Master, and was affirmed on the following pages by Lord Lyndhurst LC. who did not however go into these matters in any depth.

45 It is customary to describe the reception of English law in India in terms of a few vague words in the charters setting up the courts; the account given above seems better directed to the motives which really produced this reception. 
were taken to imply this. In other areas, British rule was extended slowly in the form of a protectorate, and English law slipped in gradually through mercantile custom or express legislative innovation.

Other British acquisitions in recent generations have been more temporary (such as the League of Nations mandates in the Near East), and consequently in most little was done to introduce any English law, and that in detail rather than en masse. ${ }^{46}$

Colonies in the New World whose chequered history might have been expected to cause difficulties were often in practice treated as settled colonies. Dutch law was not retained in New York, ${ }^{47}$ nor any Swedish in Delaware, ${ }^{48}$ nor any Spanish in any of the West Indian islands, and even a few conquered French islands seem to have been treated as settled colonies.

\section{B. Conquered Colonies}

\section{(1) The Rules Which Apply Initially}

Having decided what are settled colonies and what conquered we may now turn to the question of what rules govern each class, beginning with conquered colonies.

As we shall see, it does matter who was the other sovereign from whom the British Crown conquered the territory, but there is almost no law to be found on this subject. Some colonies, including some now making up part of the United States of America, changed hands more than once. This situation was even more common in the West Indies and reached a climax at the time of the Napoleonic Wars. St. Martin's, for instance, was a divided island which had been under French rule as to part, and under Dutch rule as to the rest of the island. During these wars the Dutch captured the French part but the French reconquered it before the British arrived on the scene and in their turn conquered the island. By later treaty between Britain and France, persons who had been under French rule at a time which happened to be before the Dutch occupation, could get compensation for loss of property. A Mr. Gumbe put in such a claim in respect of property he had had in the French part of St. Martin's, and eventually on appeal the Privy Council held ${ }^{49}$ that the reconquest by the French from the Dutch was a mere resumption of the French rule. Therefore the claimant was in the same position as though the French had been the sole rulers before the British came. The case is not really one of the law in a British conquered colony but it is probably as close a decision as can be found. Whether it allows one to ignore all previous rulers before the one from whom Britain conquered a colony is a difficult question. In any event, it is to be noted that in practice the existence of a history of government under some previous European sovereign, before the sovereign from whom British forces conquered a colony, is almost always ignored. $\mathbf{5 0}$

The general rule for all conquered colonies is that almost all of the existing laws remain in force unless and until the proper British

16 There were exceptions, such as Tanganyika, former German New Guinea and the British parts of Togoland and the Cameroons.

17 Story, supra, n. 39 at 107, 109.

ts Chafee, Book Review (1947) 57 Harv. L. Rev. 399 at 410.

"y Gumbe's Case (1834) 2 Knapp 369 at 12 E.R. 524 (P.C.).

:w Examples may be found in Malacca, Ceylon. Cyprus and St. Lucia. Similarly, a number of British conquered colonies were treated as though they were settled by British settlers, e.g. Delaware, New York, Gibraltar, Nova Scotia, and parts of the Gold Coast (now Ghana). 
authorities change them. This rule is very well-established and is recited by almost every case on the subject of the reception of English law. ${ }^{51}$

There seem to be a few exceptions to this general rule that the existing laws continue in force. We have noted above the debate as to whether then laws of a conquered pagan ruler could be allowed to continue and the eventual decision ${ }^{52}$ that they could. This rule would in general do more justice to the inhabitants but it was subject to the disadvantage that a few very strange unjust or barbaric laws might thereby be left in force. There is a considerable body of authority for the proposition that such barbaric rules of law would be found to be against public policy and therefore not be enforced. ${ }^{53}$ Thus it was said in 1693:54

And where it is said in Calvin's case, that the laws of a conquer'd heathen country do immediately cease, that may be true of laws for religion, but it seems otherwise of laws touching the government.

This early case puts the distinction between religious and other laws, but it is doubtful that distinction was meant to be any other than an example of the difference between laws broadly acceptable to the new ruler and those completely against his public policy.

The Privy Council in 1722 was a little more specific, and mentioned as abrogated any laws which are "contrary to our religion, or enact any that is malum in se ...."55 In such cases, they said, the laws of the conquering country must prevail. The leading case on this question of laws against public policy is Mostyn v. Fabrigas, where Gould J. said in 1773 that the old cruel punishments provided by the former criminal law of Minorca ceased to apply once the British had conquered the island: "Every English governor knew he could not inflict the torture; the constitution of this country put an end to that idea."56

This mention of the constitution brings us to a related point. A moment's reflection will show that the conqueror cannot retain unimpaired the constitutional law of the previous sovereign, for constitutional law is the essence of the power of the new sovereign over the territory and its inhabitants. ${ }^{57}$ It is inconceivable, for instance, that the constitutional law formerly prevailing could remain should the previous constitution have been republican. Oddly enough though, there does seem to have been a widespread assumption in South Africa and (Southern) Rhodesia (both of which in the wake of the British conquest retained or adopted Roman-Dutch) that Roman-Dutch constitutional law would prevail. 58

\section{A different opinion was however recognized in the South African case}

51 Among the leading cases are Calvin's Case, supra, n. 40; Memorandum (1722) 2 Peere Wms. 75, 24 E.R. 646 (P.C.); Campbell v. Hall, supra, n. 35; Ruding v. Smith (1821) 2 Hag. Con. 271 at 380, 382, 161 E.R. 774 at 777 . 778; Blankard v. Galdy (1693) 4 Mod. 222 at 225-26 (K.B.), 2 Salk. 411-12, Holt K.B. 341, Comb. 228,87 E.R. 359 at 361-62, 91 E.R. 356 at 357, 90 E.R. 1089 at 445; R. v. Vaughan (1769) 4 Burr. 2494 at 2500, 98 E.R. 308 at 311 (K.B.).

32 Campbell v. Hall, supra, n. 35 at 209 (Cowp.).

33 Blankard v. Galdy, supra, n. 51 at 412 (Salk.), 357 (E.R.).

st Id. at 228 (Comb.), 445 (E.R.).

ss Memorandum, supra, n. 51. Also mentioned are cases where the old law is silent, but that is of course ex hypothesi not a refusal by the new British courts to recognize the old law.

36 Mostyn v. Fabrigas (1775) 1 Cowp. 161, 98 E.R. 1021, 20 St. Tr. at 226-38, and especially at 181 (K.B.). Nares and Blackstone JJ. concurred with Gould J. Unfortunately there was no final decision in this case.

57 Ridges' Constitutional Law 480 (8th ed. 1950); Chitty, A Treatise on the Law of the Prerogatives of the Crown 25 (1820).

so See for instance, a letter to the Editor of The Times November 23, 1965 by Mr. A. M. Honore on the subject of the Rhodesian treason law, and a reply on November 25 by Messrs. Blom-Cooper and Draper, and on the same subject articles in [1966] Crim. L. Rev. 5 at 8-9, (citing only Mr. Gardiner's article, infra, n. 70) and [1967] Cam. L.J. 189. 
of Union Government v. Estate of Whittaker ${ }^{59}$ where it was said that although in general the law of the previous sovereign remains, the Crown's position vis-a-vis the courts and government is a different thing. In support of this proposition, the court cited Donegani v. Donegani, ${ }^{60}$ a case from Quebec. Indeed, this has always been the view taken in the Province of Quebec (which only received English law as to criminal matters and kept French law for property and civil rights), and so firmly has that view been held, that it seems never to have been questioned. Thus the occasion for discussing it has rarely arisen. A recent study by Mr. Justice Pigeon (as he now is) makes this clear. ${ }^{61}$ One need only look at the Quebec cases to note that the discussion of constitutional principles and the prerogative, or indeed of public law generally, is always in terms of English law and never that of France or any province of old France. ${ }^{62}$ One of the few discussions of this point is that given by Dean Walton, who in his book The Scope and Interpretation of the Civil Code of Lower Canada ${ }^{63}$ said: "The conquest of Canada in 1763 had the effect of substituting the public law of England for that of France."

This general principle was approved by Kellock J. of the Supreme Court of Canada in Chaput v. Romain, ${ }^{64}$ the other members of the court not dealing with this question. The judge quoted a passage from Lareau's Histoire du Droit Canadien to the effect that British constitutional law was introduced, and then continued:

Questions which concern the relation of the subject to the administration of justice in its broadest sense are subject to the control of the Courts, and are, therefore, governed by then law of England and not by that of France.

citing Corporation du Comté d'Arthabaska v. Patoine. ${ }^{65}$ In that latter case Ramsay J. had said:66

I have quoted English law on this subject, for it, I think, determines the point. Municipal institutions, such as those we have, are derived form the English law, and our courts have the general prerogatives of English courts. These last are derived from the authority of the Sovereign, and as the administration of justice is one of the greater rights of the Crown it is governed by the public law of the empire.

There is authority for this view in Privy Council decisions as well, the latter of which appears to put the matter beyond all doubt.67

These are cases from the Province of Quebec, but South African writers have not entirely ignored this principle either, express recognition of it being found in Nathan's Common Law of South Africa (quoting Tarring ${ }^{69}$ ), and an article ${ }^{70}$ on treason published just after the Boer War. ${ }^{71}$

69 [1916] A.D. 194 at 203-04; accord., Ruding v. Smith (1821) 2 Hag. Con. 371 at 382, 161 E.R. 774 at 778; "all laws connected with the exercise of the sovereign authority." In Sachs v. Donges 1950(2) S.A. 265, and Fellner v. Minister of the Interior 1954(4) S.A.523 at 536, the prerogative was based on English law. See also n. 67 infra.

6o Donegani v. Donegani (1835) 3 Knapp 63, 12 E.R. 571.

61 Pigeon, L.P., Rédaction et Interprétation des Lois (1965), esp. at 40-41.

62. The conflict of laws basis of constitutional law is English also: $R$. v. National Trust Co. [1933] S.C.R. 670.

6.3 (1907), at 26-51, esp. at 26-27. See also his article The Legal System of Quebec (1913) 33 Can. L.T. 280.

st Chaput v. Romain [1955] S.C.R. 834, 1 D.L.R. (2d) 241 at 259. It is also interesting that the British North America Act, 1867, says in the Preamble that Canada is to have a constitution similar in principle to that of the United Kingdom.

os (1886) 4 Dorion Que. Q.B. 364 at 370.

66 Id.

67 Abbott v. Fraser (1874) L.R. 6 P.C. 96 at 106-07, 120; Madzimbamuto v. Lardner. Burke [1968] 3 All E.R. 561 at 572 A.E, (P.C.) (Rhod.); Kodeeswaran v. A.G. [1962]2 W.L.R. 456 at $459-60$ (P.C.) (Ceylon).

68 Vol 1 at $27 \cdot 28$ (2d ed. 1913).

os Law of the Colonies 23 (1913), though nothing there seems relevant. But cf. Cameron v. Kyte (1835) 3 Knapp 332, 12 E.R. 678, where Parke B. speaks of the King being the successor of the States General of the Seven Provinces, in a captured Dutch colony! 
Some recognition of this principle is also found in $R e$ Adam, a decision that although the old law of the conquered colony sets the rights and duties of an alien, vis-à-vis the Crown his rights and duties must be set by the law of England.72 A stronger case is Sammut v. Strickland, an appeal from Malta in 1938, where it was held that the court below had been wrong in looking to Roman law for the powers of the sovereign, for they should have looked to English common law for the prerogative, even though Malta was a conquered colony. ${ }^{73}$

The most detailed consideration of which parts of the old constitutional law must be taken to have been superseded on the conquest is to be found in Walton's above-mentioned book. He suggests that English law replaces the former law as to the duties of citizens, the powers and duties of public authorities, public policy as to contracts [sed quaere], prerogative rights of the Crown, control over corporations [sed quaere], public lands, public contracts, suits against the Crown, the prerogative writs, administration of justice, liability of public officials, and administrative law. ${ }^{74} \mathrm{~A}$ Quebec decision ${ }^{75}$ includes admiralty law, on the ground that it forms part of the "public law".

But one must not think that all the rights of the Crown fall under this rubric of constitutional law. It has been suggested, for instance, that the Crown's title to the bed of navigable rivers is governed by the local law, and that the British sovereign merely takes over such rights from the former ruler. ${ }^{76}$ The same may be true of suits against the Crown ${ }^{77}$ and priority on insolvency..$^{78}$

Another problem, which was much discussed in Canada at one time,${ }^{79}$ was the significance of the treaty under which Britain obtained the conquered colony. If this treaty contained stipulations as to what law was to apply in the colony would these provisions have force in the colonial courts? The significance of this for Canada was that the terms of cession of Quebec and Montreal and the formal Treaty of Paris provided that the inhabitants were to retain their laws and religion. The British government (after a few years' delay) kept these promises so the occasion for testing their enforceability has not arisen in Canada, but

70 Gardiner, Notes on the Law of Treason (1901) 18 S. Afr. LJ. 142 at 143-44. This writer expresses the view that the authorities are too scanty for certainty, but the only ones he cites are $R$. v. Botha 1 Searle 149 and $R$. v. Maclane (1797) 26 St. Tr. 721 at 823 (Que.). The article in [1966] Crim. L. Rev. at 8.9 reaches the contrary conclusion but does not cite the authorities discussed on these pages.

7I In any event, one would imagine that the fact that South Africa not only gained independence but left the Commonwealth would tend to make the question an academic one there.

72 Re Adam (1837) 1 Moo. P.C. 460 at 470, 12 E.R. 889 at 893 (P.C.).

7] [1938] 3 All E.R. 693 at 699. But cf. Advocate.General of Bengal v. Ranee Surnomoye Dossee (1863) 2 Moo. P.C. N.S. 22 at 61,15 E.R. 811 at 825, where it was held that introduction of British sovereignty would not introduce English rules of forfeiture for felo de se.

On the other hand, it is suggested in Ruding v. Smith, supra n. 51, that not only does the law as to sovereignty change, but the new British settlers are not subject to the old law. This is illogical, for if the rules as to sovereignty are abrogated, the remaining rules of the old law ex hypothesi are matters of private law and so fit for all inhabitants.

7 Walton, supra, n. 63, especially at $28,30,31,32-33,34,37,38,40,42,43,47$; and 33 Can. L.T. at 287-90. As to privilege of witnesses, accord, Langelier v. Giroux (1932) 52 Que. K.B. 113, and as to courts generally. Pigeon, supra, n. 61 at 41 . As to administrative law, accord, Alliance des Professeurs v. Quebec Labour Relations Board [1953] 2 S.C.R. 140. As to contempt of court, accord, Sommer v. R. (1963) 40 C.R. 417 at 425.26 (Que. C.A.).

73 Baldwin v. Gibbon (1813) Stuart K.B. 72 at 74.

76 In re Provincial Fisheries (1896) 26 S.C.R. 444 at 529, per Strong C.J.C.; this point was not mentioned on appeal, [1898] A.C. 700 (P.C.).

7 Hettihewage Siman Appu v. Queen's Advocate (1884) 9 App. Cas. 571 at 584-85 (P.C.) (Ceylon); cf. Kodeeswaran v. A.G. [1970] 2 W.L.R. 456 at 460,462 (P.C.).

78 Exchange Bank of Canada v. R. (1886) 11 App. Cas. 157 at 164 (P.C.) (Que.); cf. In re Silver Bros. Ltd. [1932] A.C. 514 (P.C.) (Can.).

${ }^{9}$ See for instance, Kennedy, Documents of the Canadian Constitution 58 (1918), and Mazères, The Canadian Freeholder; and Hey C.J. in 2 L.C. Jur. Appendix, at ii-iii. 
some authority from other areas exists. In Ruding v. Smith ${ }^{80}$ the court mentioned the terms of capitulation of the Cape and said that they gave no rights to British subjects; whether this implies that they gave enforceable rights to the Dutch inhabitants is unclear. In $R e A_{d a m^{81}}$ the Privy Council said that one looks to French law in Mauritius because the island had "been surrendered on the condition, that the inhabitants should preserve their religious laws and customs. . ."82 This was of course a bare dictum. General principles are not of much help either. It is well settled that a treaty does not have any effect in domestic law (in the absence of implementing legislation), 83 though of course ordinary treaties are indirectly enforceable through diplomatic channels by governments on behalf of their nationals. Treaties of cession do not fit into this framework easily for by their nature they effect a severance between the former government and the inhabitants and ex hypothesi the inhabitants cease to be nationals of the ceding power. This fact cuts both ways and could be used as an argument either against such treaties' having any legal effect whatever, or in favor of their being intended, because of their exceptional nature, to be enforceable by the individual inhabitants in the colonial courts.

On the whole though, it is difficult to believe that even these treaties could impinge upon Parliament's sovereign power to change the law by a new statute. ${ }^{84}$ There were apparently no complaints when certain areas of English evidentiary and mercantile law were introduced into Quebec and South Africa, or even when Roman-Dutch law was replaced bodily by English law in British Guiana (now Guyana).

Indeed, the Privy Council has twice held that such treaties have no domestic effect. In Vajesingji Joravarsing $j i$ v. Secretary of State, ${ }^{85}$ Lord Dunedin said:

\begin{abstract}
When a territory is acquired by a sovereign state for the first time that is an act of state. It matters not how the acquisition has been brought about. It may be by conquest, it may be by cession following on treaty, it may be by occupation of territory hitherto unoccupied by a recognized ruler. In all cases the result is the same. Any inhabitant of the territory can make good in the municipal courts established by the new sovereign only such rights as that sovereign has, through his officers, recognized. Such rights as he had under the rule of his predecessors avail him nothing. Nay more, even if in a treaty of cession it is stipulated that certain inhabitants should enjoy certain rights, that does not give a title to those inhabitants to enforce those stipulations in the municipal courts.
\end{abstract}

This was quoted and applied in Hoani Te Heuheu Tukino v. Aotea District Maori Land Board.86

Should no representative government be established this rule could work great injustice. But if there be a responsible democratic legislature in the territory and it have the power to implement the treaty or not as it choose there is not likely to be any injustice. After all, the existing laws

\footnotetext{
su Supra, n. 51 at 379 (Hag.), 777 (E.R.).

81 (1837) 1 Moo. P.C. 460 at 470, 12 E.R. 889 at 893. Cf. Sammut v. Strickland, supra, n. 73. There is a dictum in Renaud v. Lamothe (1902) 32 S.C.R. 357 at 363 that the terms of capitulation have as much force as statutes of the Empire, and a similar one in Re Marriage Laws (1912) 46 S.C.R. 132 at 403.

82 Should this read "religion, laws, and customs"? The misprint (if any) is in Moore's Reports.

*3 Glenwood Lumber Co. v. Phillips [1904] A.C. 405 (P.C.).

s4 Accord, Denning L.J. in Nyali Ltd. v. A.G. [1956] 1 Q.B. 1 at 15 (C.A.), speaking of protectorates. (The case was affirmed on other grounds by the House of Lords, [1957] A.C. 253.) As to the King alone, cf. Chitty, supra, n. 57 at 29,32 .

85 (1924) L.R. 51 Ind. App. 357, quoting Cook v. Sprigg [1899] A.C. 572.

t6 [1941] A.C. 308 (P.C.) (N.Z.). A number of recent Canadian decisions have held the same with respect to treaties made with local Indians. See Sigeareak v. R. [1966] S.C.R. 645 and cases there cited.
} 
will (with the narrow exceptions noted above) remain in force unless and until some positive legislation changes them. And that in turn leads us to our next proposition.

\section{(2) Changes in the Law Initially Applying}

Obviously the Imperial Parliament, or the local colonial legislature, can change the law in the conquered territory. The question which causes some difficulty, however, is whether the Queen can do so under the prerogative and in the absence of any empowering statute.

Calvin's Case ${ }^{87}$ speaks obiter of the power of the new King to change the law of the conquered territory, but this could well refer only to the position vis-à-vis the former ruler or the new subjects, and not to the rights of King and Parliament inter se. Besides, the case is one decided long before the English Civil War and the Revolution of 1688; events which had a considerable impact upon the scope of the prerogative. The Memorandum of a Privy Council decision of $1722^{88}$ also speaks of the power of the King to change the law, but again it is not certain whether this refers to his prerogative or to the power of the King in Parliament.

This problem forms the subject of the most celebrated decision on colonial law, Campbell v. Hall, decided in $1774^{89}$. Grenada had been captured from France, and by the Royal Proclamation of 1763, a representative legislature was promised the island. But before this was instituted another Royal Proclamation (not authorized by statute) imposed an export duty. The plaintiff claimed the tax was illegal and sued in England to recover the amounts he had been required to pay. The Court of King's Bench agreed with him and gave him judgment. Lord Mansfield, for the Court, said that when the island was conquered the King could keep it or not as he wished, and had certain legislative power over it:

The 6th and last proposition is, that if the King (and when I say the King, I always mean the King without the concurrence of Parliament), has a power to alter the old and to introduce new laws in a conquered colony, this legislation being subordinate, that is, subordinate to his own authority in Parliament, he cannot make any new change contrary to fundamental principles: he cannot except any inhabitant from that particular dominion; as for instance, from the laws of trade, or from the power of Parliament, or give him privileges exclusive of his other subjects; and so in many other instances which might be put. ${ }^{90}$

Therefore, had the King imposed the tax before 7 October 1763, his proclamation would have been valid. But on that date, he pledged an assembly to enact laws, and on 9 April 1764 even instructed the governor to call one. This was an irrevocable grant of legislation by assembly, and so he had put it out of his power to legislate. Therefore, the tax was illegal.

Technically that decision was not binding on colonial courts but it was followed in 1835 by the Privy Council in Jepson v. Riera. ${ }^{91}$ There it was held the King had effectively exercised his prerogative to impose English law on the ceded colony of Gibraltar. Furthermore, the Board held that the precise instrument used to effect this purpose did not

\footnotetext{
87 (1609) 7 Co. Rep. 1a at 7b, 77 E.R. 377 at 398.

a 2 Peere Wms. 75, 24 E.R. 646.

"9 1 Cowp. 204, 98 E.R. 1045; Loff. 655, 98 E.R. 848, 20 St. Tr. 239.

90 At 209 (Cowp.) 1049 (E.R.). Indeed, lest this be thought antiquarian, it has been said that the British Zone of Occupation in Germany after World War Two was governed under the prerogative.

913 Knapp. 130 at 151, 152; 12 E.R. 598 at 606.
} 
matter and that an Order in Council was not necessary; a charter regulating the courts was sufficient. There was no question there of any promise of an assembly. But another decision ${ }^{92}$ the same year held that the appointment of a governor was not an automatic delegation of the King's legislative power to the governor. Therefore, a purported abolition by the governor of a tax in a conquered colony was invalid because neither his commission nor his instructions authorized this. Nor was the King's mere acquiescence enough, for the inhabitants should be able to see on the face of new laws the authority by which they were made. There is also authority from Jamaica in support of the prerogative power to introduce English law. ${ }^{93}$

Modern Privy Council decisions have both confirmed and qualified the rules in Campbell v. Hall. In Abeyesekera v. Jayatilake ${ }^{94}$ the Board said of the conquered colony's subjection to legislation under the prerogative that:

This status endures merely so long as the Island is not constituted a colony, but remains simply a conquest. Once it becomes a colony the King can act only within the constitution granted and applicable to that colony. Henceforward the King, by his own act-from which he may not derogate-has, subject to all reservations, precluded himself from proceeding otherwise.

But of course if the prerogative power was reserved in the constitution granted, then it remains and can be exercised. Therefore in that case because of an express reservation by the Crown of the right to legislate for the island a later change in the composition of the legislative council, even though it was not empowered by statute, was upheld. Sammut v. Strickland ${ }^{95}$ was to the same effect and indeed extended this rule to colonies ceded by the inhabitants even though not conquered or ceded by any ruler. That case also interprets Campbell v. Hall as being a case where the Crown had tried to legislate by the prerogative while there was a legislature provided for and suggests that it would be different were the Crown first to terminate the legislature's existence. That is contrary to what most commentators have taken Campbell v. Hall to mean, and is probably only a dictum, for in Sammut v. Strickland there was an Imperial Act deeming the previous constitution to reserve in the Crown a power of revocation. And in any event, Lord Maugham L.C. there admitted that the power of revocation must be reserved to exist so the result is the same and his dictum is harmless.

The rule in Campbell v. Hall therefore imposes a very severe qualification upon the King's freedom (noted above) to disregard the terms of the treaty of cession, and abrogate the inhabitants' rights against their wills. But it has been suggested ${ }^{96}$ recently that there may of necessity be an exception to the rule for cases where the local legislature is unable to act.

An important limitation on the rule in Campbell v. Hall was suggested by Luxmoore J. in the English Chancery Division ${ }^{97}$ when he

92 Cameron v. Kyte (1835) 3 Knapp 332, 12 E.R. 678 (P.C.).

9:1 Jacquet v. Edwards (1867) I S.C.J.B. 70, 1 Stephens S.C.D. 414.

94 [1932] A.C. 260 at 264 (P.C.).

9: [1938] A.C. 678, [1938] 3 All E.R. 693 (P.C.) (Malta). Sammut was approved in Newbery v. R. (1965) 7 F.L.R. 34, a decision from Norfolk Island, but that case held that a general power in the Crown to provide a government, contained in an Imperial Act, allowed a "legislature" to be revoked, and 80 the common-law rule was not decisive there.

Sabally v. A.G. [1965] 1 Q.B. 273 at 293, 299-300 (C.A.).

97 North Charterland Exploration Co. v. R. [1931] Ch. 169 at 186-87. This decision is consonant with the passage from Abeyesekera's case quoted above, $n$. 94, though that case was decided later. Indeed, this case (at 187) foreshadows the essential reasoning in the Abeyesekera and Sammut cases, supra. 
held that the rule did not extend to British protectorates, these not being part of His Majesty's dominions. And even had that rule applied to protectorates, he felt the Foreign Jurisdiction Act, $1890^{98}$ (giving the Crown legislative power to respect to non-British territory) would have abrogated it.

\section{Settled Colonies}

As we saw above, ${ }^{99}$ the general rule is that in a true settled colony the settlers bring with them the existing English law, but not new English statutes enacted after the colony's foundation.

The first thing which seems a little odd about this rule is the emphasis which it places on self help for many writers emphasize the acts of the very settlers, not saying that the general law gives them English law, but rather that they "carry" it with them. (This of course ignores the fact that one could be a British subject and not be English or subject to English law, ${ }^{100}$ a fact not really fully appreciated). Ridges' Constitutional $L a w^{101}$ attempts to circumscribe the rule and suggests that settlement by British subjects is never free of the Crown's powers. Their act of settlement (or even conquest!), the author submits, is the sovereign's and extends his dominions, referring to India where the position of the Honourable Company before the Mutiny made this point relevant. But the author has to admit that the Brooke family's reign over Sarawak raises difficulties, for the British government seem to have treated it as foreign territory though the Brookes were British subjects.

On the other hand, although the British settlers seem to act as the King's agents, whether their authority to annex by settlement depends on his assent or his ratification is unclear. The problem arose in British Honduras where British subjects had settled as early as 1817 , but the Crown did not formally annex any territory there until 1862 (despite tacit withdrawal of Spanish sovereignty around 1800).102 The Privy Council held103 that British "territorial dominion" (which must mean annexation as a full-fledged colony) began at least as early as the first Crown grants of land and so before the annexation in 1862. Therefore, it looks as though very little is needed in the way of ratification by the Crown of the settlers' annexation, which blunts the effect of a considered dictum by Lord Mansfield in Campbell v. Hall that "no colony can be settled without authority from the Crown."104

But it is doubtful that the settlers themselves have any say in the matter, even if the classic authorities on the subject do frame the rules in terms of the benefits enjoyed by the settlers. No one has ever suggested that by desiring not to be governed by English law the settlers could have any other law apply to them, unless the Voortrekkers of South Africa be an exception. But their case may be best explained as an extension of the territory of the colonies in which they lived, which only reinforces the proposition that their will was irrelevant. By fleeing from British suzerainty they only succeeded in bringing it with them. This in turn must be a corollary of the great principle enunciated in Calvin's

\footnotetext{
9v (Imp.) 53 \& 54 Vict., c. 37.

99 Supra, p. 35.

100 Cf. Roberts-Wray, Commonwealth and Colonial Law 856 (1966).

101 at $480-81$ (8th ed. 1950).

102 See Roberts-Wray, supra, n. 100 at 818-26.

${ }^{103}$ A.G. v. Bristowe (1880) 6 App. Cas. 143 at 148 (P.C.) (B.H.).

tor Campbell v. Hall, supra, n. 89 at 287 (St. Tr.).
} 
Case, ${ }^{105}$ that allegiance and sovereignty pertain to a monarch's person and his subjects, and not to territories.

One problem little discussed is the precise date as of which one ascertains the English law which is received, presumably because in most colonies this date is fixed by statute. Most writers say that it is the date of settlement or the foundation of the colony, ${ }^{106}$ but this could be inconvenient. Some colonies did not receive many settlers or have much government machinery for many years. Thus, they would be in danger of being saddled with very old English law without the benefit of either ameliorating English statutes or a local legislature to remedy these defects. Therefore, there is some reason to suggest that the date of reception should be the date of institution of the first legislature in the colony. There is some authority for this proposition as well. Barton J. in Quan Yick v. Hinds ${ }^{107}$ tried to base this rule on a passage in Forsyth's Cases and Opinions ${ }^{108}$ which says that all Acts are in force in the colony whether passed before or after its acquisition "which by reasonable construction must be supposed to apply to the Colonies." But with respect, this passage seems to speak of interpretation of the statutes to see whether they are intended to extend to the colonies and this must refer to Imperial statutes in force proprio vigore and not English law received by virtue of settlement. This is a distinction emphasized above. 109 A better basis for choice of the date of institution of a local legislature is found in Yonge v. Blaikie, 110 a decision from Newfoundland, a colony which received its first legislature centuries after settlement or annexation. The Chief Justice there said:

But with every respect for the opinion of such eminent men, it has fallen within my experience to learn that the colonial courts date the discontinuance of English statute laws, not from the time of the colony being settled, but from the institution of a local legislature in the colony; and the reason of the rule is, I think with the interpretation given it by the colonial lawyers.

He suggests, therefore, that the basis of the rule is simply the colonial courts' practice and the wisdom of the matter. No better basis could be found, and it is interesting to find such a rule made by the colonies for themselves and not one laid down by the English domestic courts the way so many of the basic rules have been. On the other hand, there are decisions (and a host of dicta) which adopt the date of settlement without mention of the legislature's founding date. ${ }^{111}$

We saw above that the Crown has prerogative power to legislate for a conquered colony (unless it has irrevocably granted an assembly) but the same is in general not true of a settled colony. Even in a settled colony, the Crown can under the prerogative establish a legislature ${ }^{112}$ or introduce courts to administer English law. ${ }^{113}$ But as English law is in force by the very fact of settlement, and as it is a fundamental rule of English law that in general the prerogative does not give the King the

\footnotetext{
ius Supra, n. 87.

106 For instance, MacRae, Constitutional Law 57.

107 Quan Yick v. Hinds (1905) 2 C.L.R. 345 at 366.

108 At 20.

109 Supra, p. 31.

110 (1822) 1 Nfld. L.R. 276 at 283.

"1" E.g., Memorandum, supra, n. 51; $R$. v. Vaughan, supra, n. 51.

112 Kielly v. Carson (1842) 4 Moo. P.C. 63 at 85,13 E.R. 225 at 233 (P.C.) (Nfld.).

"Is Id.; Re Lord Bishop of Natal (1864) 3 Moo. P.C. (N.S.) 115 at 148, 16 E.R. 43 at 56. On what kind of law these courts can administer, see a detailed history and study by Dr. Enid Campbell, The Royal Prerogative to Create Colonial Courts (1964) 4 Sydney L. Rev. 343.
} 
power of legislation, ${ }^{114}$ one would expect there would be no general power in the King to legislate for a settled colony. and this was in fact the rule at common law,115 though the British Settlements Act, $1887^{116}$ gave the Queen such a legislative power to regulate the administration of justice in British territories not within the jurisdiction of the legislature of any British possession.

Thus in Kielly v. Carson ${ }^{117}$ the Privy Council recited the Crown's power to establish courts and legislatures and corporations. But they said the inhabitants of a settled colony have the same rights and immunities as British subjects, and the settlers' descendants have:

... on the one hand, the same laws, and the same rights (unless they have been altered by Parliament); and on the other hand, the Crown possesses the same prerogative and the same powers of government that it does over its other subjects.

This plainly says that the Crown has no more legislative power or prerogative in a settled colony than it does in England. ${ }^{118}$ This was quoted and applied in the celebrated case of Phillips v. Eyre by Wiles J.119 And the Privy Council said in Sammut v. Strickland of settled colonies that "The Crown clearly had no prerogative right to legislate in such a case."

\section{Charters or Statutes Introducing English Law}

As we noted above ${ }^{120}$ very few colonies, even settled ones, received English law solely under the common-law rule. Most obtained it through some form of legislation providing that the Law of England as of a certain date should be in force in the colony. Usually law inapplicable or unsuitable to the colony was expressly excepted. ${ }^{121}$

Where the colony had been a conquered colony English law could be introduced by the King under the prerogative, as we saw above; the only exception was the case where he had granted an assembly. But many settled colonies had English law introduced by some form of prerogative instrument, ${ }^{122}$ and it is possible that not all these instruments were authorized by statute. ${ }^{123}$ Of course English law was in force in these settled colonies because of the common law in any event, but these prerogative instruments usually fixed the date as of which it was to be received and that was often not the date of settlement or even the date of the institution of a legislature. But no one ever seems to have ever questioned the effectiveness of this procedure, ${ }^{124}$ and it is a convenient one, especially as the exact date of settlement must in most cases be totally impossible to ascertain. Therefore, on the ground of convenience,

\footnotetext{
114 The Case of Proclamations (1609) 12 Co. Rep. 74, 77 E.R. 1352; The Zamora [1916] 2 A.C. 77 (P.C.).

115 MacRae, supra, n. 106 at 57, 58; Re Lord Bishop of Natal, supra, n. 113 at 56.57 (E.R.).

11650 \& 51 Vict., c. 54.

112 Supra, n. 112.

In And many subsequent cases say the prerogative is no greater in a settled colony than in England: see MacRae, supra n. 106; Re Lord Bishop of Natal, supra, n. 113 ; and Liquidators of the Maritime Bank of Canada v. Receiver General of New Brunstvick [1892] A.C. 437 (P.C.).

1ty (1871) 40 L.J.Q.B. 28 at 35.

120 Supra, p. 36.

1:21 Even if there were no such express exception, the courts would infer it: infra. p. 50 .

$1: 2$ As was the case in British Columbia where an Imperial statute gave the Governor the legislative power. In most cases there was statutory authority under a specific Imperial Act or under the British Settlements Acts. 1843-1945.

1:s Mr. Roberts-Wray points out that the Royal proclamation of 1763 covered some settled colonies.

1:4 Indeed, in A.-G. Alta. v. Huggard Assets Ltd. [1953] A.C. 420 at 442, the Privy Council held effective a clause introducing English land law in the Royal Charter of the Hudson's Bay Company.
} 
we must reckon this a further ${ }^{125}$ exception to the rule that the sovereign cannot in general legislate under the prerogative for settled colonies.

Of course English law has often been introduced by a colonial statute or an Imperial statute. One little-noted aspect of a wholesale introduction by Imperial statute of all or a large part of English law was dealt with in Bank of Upper Canada v. Bethune ${ }^{126}$ so long ago as 1833 . We have noted that Imperial statutes in force proprio vigore in the colony are a very different thing from English law introduced into the colony as such. But the two overlap in an Imperial statute which introduces English law into the colony. If at the time of this introduction there are Imperial statutes in force in the colony, which are not in force in England, does the introduction of English law repeal them to the extent that they are part of the colony's law? This problem would be acute where the Imperial statutes in force proprio vigore dealt with one topic and the differing English law as to that very topic was introduced by a later Imperial statute. In Bethune's case, Robinson C.J. said that no such repeal is to be implied and so the introduction of English law has no reference at all to Imperial statutes already in force proprio vigore.

What is the general effect of a wholesale introduction of English law into a colony by the terms of a statute or prerogative instrument? Can one generalize as to this topic? After all, the wording of the various statutes introducing English law into different colonies vary somewhat. Some mention only common law and equity, while others mention statutes too; the simplest ones just introduce "the law of England." The best approach to the problem is that laid down by the Full Court in New South Wales as early as 1833, in Macdonald v. Levy. ${ }^{127}$ There Forbes C.J. pointed out that the statute in question was passed after the establishment of the settled colony. As there were well-settled rules governing the reception of English law in such a colony, and as the words of the statute were not in any manner inconsistent with the common law, the Court held that the statute was only intended to confirm the common-law rule, not to alter it. Therefore, the meaning of "applicability" of English statutes would be the same as that of the common law, as expounded by Blackstone.

One odd decision to the contrary is Keewatin Power v. Town of Kenora. ${ }^{128}$ The trial judge had held that even though Ontario legislation introducing English law had made no express exception for inapplicable or unsuitable laws one would read this exception into the statute because the common-law rule had such an exception.129 The Ontario Court of Appeal reversed this but their decision is of doubtful validity for the Ontario courts have repeatedly held various English statutes not to be in force because inapplicable, ${ }^{130}$ applying the same Ontario legislation as was in question in the Keewatin case. There has been at least one

\footnotetext{
125. The other exceptions being introduction of courts, legislatures and corporations, what the prerogative allows in England, and what the British Settlements Acts allow.

126 (1833) 4 U.C.Q.B. (O.S.) 165 at 171-72.

127 (1883) Legge 39.

12* (1906) 13 O.L.R. 237, rev'd. (1908) 16 O.L.R. 184 at 189 (C.A.).

129 Re Provincial Fisheries (1896) 26 S.C.R. 444 at 528, per Strong C.J.C. though this point was not mentioned on appeal [1898] A.C. 700 (P.C.).

1.u Hixon v. Reaveley (1904) 9 O.L.R. 6 holds some rules of waste not to be in force. Mercer v. Hewston (1859) 9 U.C.C.P. 349 holds the parts of the Mortmain Acts requiring enrolment not to be in force in Ontario. Doe d. Anderson v. Todd (1846) 2 U.C.Q.B. 82 at 86.87 says only applicable English law is in force in Ontario and it is a decision of the Court of Appeal.
} 
expression of views to the contrary in the Supreme Court of Canada. ${ }^{131}$ And indeed, in Fleming v. Atkinson ${ }^{132}$ that court held that the commonlaw rule of immunity from liability for escape of one's animals onto the highway was not in force in Ontario because it was unsuitable. Jex v. McKinney was a similar decision by the Privy Council with respect to a similar British Honduras statute. ${ }^{131}$ Thus no case from any other jurisdiction appears to take the view which the Ontario Court of Appeal took in Keewatin, and even in Ontario there is binding authority to the contrary. ${ }^{134}$

Therefore, because of Macdonald v. Levy and the other cases mentioned above a minute examination of the words of a statute introducing English law is probably ill advised, despite what some modern writers urge. ${ }^{135}$ After all, Parliament is presumed not to intend to change the common law by unclear words. ${ }^{136}$

Another problem arises in some jurisdictions because local legislation has introduced English law and equity without any mention of English statutes. In an appeal from East Africa the Privy Council has held ${ }^{137}$ that English statutes in force on the relevant date are introduced by such legislation, this being part of the law which English courts would have used on that date. It must be noted, however, that the statute in question there did not effect a general introduction of English law, and imported law and equity only with respect to forfeiture of leases, a subject which (as the Privy Council pointed out) was largely controlled by statute in England on the relevant date. But the Board did not say that the rule would be different in the case of a wholesale introduction of English law.

And indeed there is good authority to the effect that this rule applies to a general introduction of English law as well. In Seng Djit Hin v. Nagurdas Purshotumdas \& Co., ${ }^{138}$ the Privy Council held that the introduction of English law for the purposes of suits on a wide variety of mercantile questions included statutes, and indeed all English statutes which could affect the outcome of such suits, whether or not these statutes were mainly mercantile in character. There is thus a difference between enacting that English mercantile law will apply and enacting that mercantile questions will be governed by English law. ${ }^{139}$

A case going even further is Booth v. Booth, ${ }^{140}$ where the High Court of Australia interpreted a statutory introduction of the "principles and rules of common law and equity" as effecting an introduction of English statutes as well, lest an absurd result be otherwise produced.

IJ1 R. v. Fares [1932] S.C.R. 78 at 81 showed Anglin J. (who had been trial judge in Keewatin) still to be of the same opinion.

1112 [1959] S.C.R. 513.

1.3. (1889) 14 App. Cas. 77 at 81 (P.C.). And a similar decision dealing with a British Columbia statute which on its terms was unqualified is Penner v. Penner [1947] 4 D.L.R. 879 (S.C.C.).

i..4 Doe d. Anderson v. Todd, supra, n. 130.

iss E.g., Roberts-Wray, Commonwealth and Colonial Law 545 (1966).

136 Maxwell, Interpretation of Statutes 78-9 (11th ed. 1962).

1.17 Bashir v. Commissioner of Lands [1960) A.C. 44 at $61-62$.

13s [1923] A.C. 444 at 448.9. Curiously enough, there seem to be contradictory expressions in another Privy Council appeal from the Straits Settlements ten years later, Shaik Saheed v. Sockalingam [1933] A.C. 342, 102 L.J.P.C.

111. These matters are thoroughly discussed by Dean G. W. Bartholomew in a paper read to the Australasian Law Conference in August 1967.

1:19 Not surprisingly, Ontario courts have taken a reference to "the laws of England" to include statutes.

141 (1935) 53 C.L.R. 1. 


\section{E. Introduction of Law by Extension of Boundaries}

It was very common in the past for colonies to be established initially with a small area and then later to have their boundaries extended. Often this extension involved an annexation of territory which had not previously been subject to the same law as the principal colony and it seems doubtful that the necessary legislation always made provision for the extension of the law of the colony to the new territory. For instance, in 1912, Ontario's and Quebec's boundaries were extended to include areas which had once formed part of the Hudson's Bay Company's domains and later part of Canada's Northwest Territories, and so had had law different from the law received and retained by Ontario and Quebec.

In such cases of legislative silence, it just seems to have been assumed that the annexation extends the law of the annexing colony to the newly-incorporated territory. This rule was confirmed by the Lord Chief Justice in the famous Jameson Raid case ${ }^{141}$ when he held that the annexation of British Bechuanaland ${ }^{142}$ to the Cape Colony had automatically extended the laws of the Cape to this territory. There is West African authority ${ }^{143}$ to the same effect.

Therefore, annexation or alteration in boundaries forms a fourth mode of reception of law, besides settlement, conquest, and legislation.

A variant of annexation is separation from the parent colony of a new area settled from the parent colony. When one colony is split off from another, either the law of the parent colony may be received or the English law in force in the parent colony may be kept, but in either event the same English law is in force in the new colony ${ }^{144}$ This matter is often regulated by statute. Examples may be found in the formation of Kentucky and Tennessee, the splitting of New Zealand, Victoria, and Queensland off from New South Wales, 145 and the constitution of part of Canada's Northwest Territories as the Yukon Territory.

South West Africa was given by statute "the Roman-Dutch law as existing and applied in the Province of the Cape of Good Hope," and this has been held ${ }^{146}$ to refer to the law as developed and expounded at the Cape, complete with local statutes and doctrines and the influence of English law (though Cape decisions would not bind if they were plainly wrong). Indeed, Hofmeyr J. thought ${ }^{147}$ that even the practice of lawyers, officials, and citizens at the Cape was relevant, just as decisions of the Cape courts were.

\section{F. Establishment of Courts}

From early times ${ }^{148}$ the Imperial Parliament passed Acts ${ }^{149}$ providing for trial in British colonies in North America of matters arising in areas of North America outside British territory. In the absence of an express

11 R. v. Jameson (1896) 65 L.J.M.C. 218 at 226.

11: Which is not the same as the present-day Bechuanaland Protectorate.

14. See Roberts-Wray, supra, n. 100 at 110-11, and authorities there cited.

1. Dale, Adoption of the Common Law by the American Colonics (1882) 30 Am. L. Reg. 553 at 562.

14: But as to South Australia see Winterbottom v. Vardon \& Sons Ltd. [1921] S.A.S.R. 364 at 368.9.

1ti R. v. Goseb [1956] S.A. 696 (H.C.S.W.A.), quoting Gideon Nkambule v. R. [1950] A.C. 379.

$10 R$. v. Goseb, id. at 701 .

11, The Mutiny Act, 6 Geo. 3, c. 18 (not in the Statutes of the Realm: see the Public General Acts for that year, at 325-26, and 1 Chalmers' Opinions of Eminent Lawyers 204 (1814)) in force 24 March 1766 w 1768 extended to 1771 by $9 \mathrm{Geo}$. 3, c. 18 then re-enacted as $15 \mathrm{Geo} .3$, c. $16,88.29,30$ extended to 1778 by $16 \mathrm{Geo}$. 3, c. 11 . Then apparently there was a gap until the Acts mentioned below.

IN" 43 Geo. 3, c. 138 , clarified by 1 \& 2 Geo. 4, c. 66, s. 5 confirmed by 22 \& 23 Vict., c. 26. 
provision, one would think that the colonies' courts, when holding such trials, were to apply the law they would apply in ordinary matters arising within the colony. Indeed, this was expressly provided by one of the later of these statutes. ${ }^{150}$ This therefore appears to be yet another mode of reception of English law.

The Foreign Jurisdiction Act ${ }^{151}$ appears to have somewhat the same effect in non-British territory, notably protectorates. Of course with the decrease in the number of protectorates and areas according extraterritoriality to British subjects, the importance of this Act has decreased.

But one must not confuse this mode of reception with legislation merely regulating or establishing courts in and for an existing colony. Some writers have been quick to attach great significance to the vaguest words in a charter or Act establishing a court of justice for a colony. But in the absence of express words in such legislation, there is no need to read such words as being intended to upset the common-law rules as to what law is in force in a settled or conquered colony. Indeed, the prerogative extends to the establishment of courts but (as we saw above) not to general legislation, especially in a settled colony. Therefore many of these instruments which were made under the prerogative without any Act of Parliament probably could not change the law in the colony even if we were to interpret them as purporting to do so.

\section{THE PARTS OF ENGLISH LAW RECEIVED}

We have examined above the various manners in which English law may be introduced into a colony and in another chapter we will consider the rule (to which we have adverted briefly) that unsuitable rules of law are not received. But here the problem is different. What parts of English law are, in principle, in force? As of what date is English law taken? What does the term "English law" encompass? We will refer primarily to the common-law position in settled colonies, but following the rule in Macdonald v. Levy ${ }^{152}$ we will assume that the same rules apply to the reception of English law pursuant to statute, in the absence of any express provision to the contrary.

\section{A. Is There a Cut-Off Date?}

If all English rules of law and statutes were part of the colony's law the result would be odd. The newest development in English law would automatically become part of the colony's law, whether the inhabitants liked it or not. In practice this would have serious effects on the colony's autonomy. This is especially so when one considers that some of these "colonies" have been independent countries for many years now. Therefore, can we say that the English law in force is frozen or cut off at the relevant date? This date could be the settlement of the colony, the establishment of the legislature, or a date chosen by legislation.

\section{(1) Statutes}

Here the problem is clear cut. Leaving aside Imperial statutes which are only in force proprio vigore, ${ }^{153}$ are any statutes received which came

1su 1 \& 2 Geo. 4, c. 66, s. 6, providing contracts, agreements, debts, liabilities and demands, or wrongs or injuries to the person or property, real or personal, were to be governed by the law of Upper Canada, except as to claims to land, which were to be governed by English law.

151 (Imp.) 53 \& 54 Vict., c. 37 , esp. s8. 6, 9

152 Supra. p. 50.

1sJ Memorandum (1722) 2 Peere Wms. 75, 24 E.R. 646; on the general subject of Imperial statutes in force proprio vigore see supra, p. 33. 
into force in England after the relevant date? The authorities agree that the answer is no, ${ }^{154}$ although limited exceptions were contended for by some American colonists around the time of the American Revolution. ${ }^{155}$

There is a corollary to this which is not immediately obvious: repeal of an English statute in England need not entail its repeal elsewhere; it would be otherwise if the repeal were an Imperial Act expressly declared to be in force in all colonies, but that would be a very rare thing. If the first English statute had come into force before the relevant date it would (unless not reasonably suitable) be in force in the colony. If its repeal in England took effect after the relevant date, the repealing statute would not be in force in the colony and so the first statute would stand unrepealed in the colony. Thus in $R$. v. Roblin ${ }^{156}$ it was held that 26 Geo. 2, c. 33 was in force in Upper Canada, and it was irrelevant that it had been repealed after 1792 in England by 3 Geo. 4, c. 75. To put it another way, the colony was given the law of England as it existed on a certain day in 1792, and the fact the statute of $26 \mathrm{Geo} .2$ was repealed in England after that did not change the fact that it had been in force in England in 1792.

An ingenious argument to the contrary was attempted in Alberta without success. The relevant statute introduced the law of England as of July 15, 1870 so far as "applicable" and so far as not modified or repealed by (among other things) any United Kingdom Act "applicable" to Alberta. Counsel argued that "applicable" must mean the same thing both times, i.e. reasonably suitable. And so a later repeal in England would be applicable even if made after 1870 if the statute it repealed was "applicable." But the court held 157 that not only would that produce a ludicrous result, but that the second use of "applicable" plainly referred to Imperial Acts in force proprio vigore. Thus the same result was reached as had been in $R$. v. Roblin. ${ }^{158}$

Nor is a statute introducing English law interpreted any differently from the common-law rule of reception, in the absence of express words to the effect that English law from time to time in force is introduced. ${ }^{159}$ Speaking of a statute introducing the procedure of the English House of Commons, the Privy Council said:160

In the absence of words of prospect or futurity, and of any context indicative of an intention 80 improbable as that of adopting by anticipation all future changes in the procedure or practice of the House of Commons, their Lordships think it would be unreasonable so to construe the standing order.

To the same effect is the Privy Council's recent decision in Bashir v. Commissioner of Lands. ${ }^{161}$

154 Castles, The Reception and Status of English Law in Australia (1963) 2 Adel. L. Rev. 1 at 14-16; Memorandum, supra, n. 152; Gray v. National Trust Co. (1915) 8 W.W.R. 1061 at 1063; Park, The Sources of Nigerian Law 29 (1963); Garrett v. Roberts (1884) 10 O.A.R. 650; Winterbottom v. Vardon \& Sons Ltd. [1921] S.A.S.R. 364 at 368; Kelly v. Jones (1852) 7 N.B.R. 473 at 474; Dedhar v. Special Commissioner [1957] E.A.L.R. 104 at 107 (C.A.)

Therefore, the passage in Terrell v. Secretary of State [1953] 2 Q.B. 482 at 495, , [1953] 2 All E.R. 490 at 494 D, referring to the repeal of the Act of Settlement in 1881, is just an embarrassing error. See also Kerr, The Reception and Codification of Systems of Law [1958] J. Afr. L. 82 at 87.89.

Conversely, some English writers of the time denied that any of the common law was in force in the colonies: sometimes this was effected by pretending that the American colonies were all conquests.

136 (1862) 21 U.C.Q.B. 352 at $354-55$.

157 Brand v. Griffin (1908) 1 Alta. L.R. 510 at 511-13, per Stuart J.; cf. Nsiah v. Union Trading Co. [1959] Ghana L.R. 79.

15s Supra, n. 156.

159 Roberts-Wray, Commonwealth and Colonial Law 545, 805, 807, 909 (1966); contra, Johnston v. Johnston [1942] O.W.N. 47 where, however, no cases were cited, and the Court of Appeal gave no reasons.

100 Barton v. Taylor (1886) 11 App. Cas. 197 at 202 (P.C.) (N.S.W.).

361 [1960] A.C. 44, 62; accord, Waldock v. Waldock [1943] 3 W.W.R. 177 at 178 (Man. K.B.). 
One does occasionally ${ }^{162}$ meet with an isolated statutory provision which introduces some part of English law as it may exist from time to time. This is an express legislative exception to the common-law rule described above, and displays the "intention so improbable" referred to in the quotation above. Whether this constitutes a delegation of legislative power is a fascinating jurisprudential question. ${ }^{163}$

\section{(2) Common Law}

There has been an ably-conducted debate in recent years as to whether or not there is a cut-off date for the reception of the common law. Dr. Allott ${ }^{164}$ thinks there is, but Dr. Park disagrees. ${ }^{165}$

It will assist us if we begin with one thing which now seems certain. Although it used to be thought that a "colonial" court should follow English decisions, 166 this is clearly no longer the law, and the "colonial" court need only follow Privy Council decisions. ${ }^{167}$ Any other rule would be ridiculous, especially because most of the former "colonies" are now independent countries. Indeed, the High Court of Australia has been emphatic in its refusal to follow a House of Lords decision ${ }^{168}$ which it thought mistaken. ${ }^{169}$ But that does not mean Australia or any other Commonwealth country has ceased to have English law just because it does not take English decisions to be binding upon it. The two things are really very different therefore. ${ }^{170}$ Indeed, it has often been held ${ }^{171}$ that the mere fact English law has been received in a colony does not compel the courts there to follow English decisions, for the "colonial" court may be just as able to interpret and apply the law as English courts. Though there are authorities in conflict, ${ }^{172}$ the Privy Council has recently held that English decisions do not bind outside England. ${ }^{173}$

It has been suggested ${ }^{174}$ that this is illogical and that the common law cannot exist without court decisions: that would be an attempt to play Hamlet without the Prince. This is so only to a degree and can be taken too far. If one disagreed with every English decision, one would not be applying the English law. But no one proposes to do that, or even to disregard most English decisions. It is just that occasionally an English decision seems wrong and a colonial court does not wish to

162 E.g. the Judicature Act of Alberta, 88. 26(b)(v), 32(a), and 33 (R.S.A. 1970, c. 193); Muzak Corp. v. C.A.P.A.C. [1953] 2 S.C.R. 182 at 194, 197; Barbados Act 56 of 1956, 8. 13.

16: See the debate between Professor Corry in Appendix 7 to the Report of the 1939 Canadian Royal Commission on Dominion-Provincial Relations at 39, and Mr. Justice Laskin, in his Constitutional Law, 40-41 (3d ed. 1966).

164 Allott, Essays in African Law, Chaps. 1 and 2 (1960).

165 Park, supra, n. 154.

166 Trimble v. Hill (1879) 5 App. Cas. 342 (P.C.).

167 Robins v. National Trust Co. [1927] A.C. 515 (P.C.); Safeway Stores Ltd. v. Harris [1948] 4 D.L.R. 187 (Man. C.A.); Anderson v. Chasney [1949] 2 W.W.R. 337 at 361 (Man. C.A.).

16s D.P.P. v. Smith [1961] A.C. 290 (H.L.).

169 Parker v. R. (1963) 111 C.L.R. 610, see also Uren v. Fairfax [1967] Austl. Argus R. 25 (H.C.).

170 11 Am. Jur. 167, Common Law \$ 13; Sayward v. Carlson (1890) 1 Wash. 29 at 40-41.

17 R. v. Cyr [1917] 3 W.W.R. 849 at $857-58$ (Alta. S.C.); Mackowecki v. Yachimyc [1917] 1 W.W.R. 1279 (Alta. C.A.); Flewelling v. Johnston (1921) 16 Alta. L.R. 409 at 413 -I4 (Alta. C.A.); 15 C.J.S. 619 (\$ I1(b)); Fleming v. Fleming [1934] O.R. 588 at 592; Hawkins v. Peterson (1863) 3 Ont. P.R. 253 at 263; $R$. v. Goseb [1956] 2 S.A. 696 at 699 (H.C.S.W.A.); R. v. Hyland (1898) 24 V.L.R. 101; Williams v. Miles (1903) 94 N.W. 705 at 708 (Neb.), per Pound C.; Dickey v. Volker (1928) 11 S.W. 2d 278 at 285-86 (Mo.); Hawkinson v. Johnston (1941) 122 Fed. $2 d 724$ at 728, cert. den. 314 U.S. 694; R. v. Chavendra [1939] S. Rhod. 218 at 226-27.

172 Pope (1910) 24 Harv. L. Rev. 6 at 10-16; but cf. at 25; Idington J. in Church v. Hill [1923] S.C.R. 642 at 643; $R$. v. Scully (1903) 23 N.Z.L.R. 380 at 382, 384 (C.A.); Hoffman, South African Law of Evidence 5 (1963); cf. Ex parte Nichols (1839) Legge 123 at 125-26, and Booth v. Booth (1935) 53 C.L.R. 1; Piro v. Foster (1943) 68 C.L.R. 313; cf. supra, n. 169.

173 Bashir v. Commissioner of Lands [1960] A.C. 44 at 62 (P.C.) (E.A.), approving Dedhar v. Commissioner [1957] E.A.C.A. 104.

17. Pope, supre, n. 172. 
follow it. This may be because the English decision seems illogical or unjust, but it is more often because the English decision seems to clash with other English decisions. Then there is no question of rejecting the common law, but rather a question of what is the common law. ${ }^{175}$ If the House of Lords overrules a Court of Appeal decision of long standing (as occasionally happens) does this mean that the lower English courts were not following English law all those years? This argument is strengthened by the fact that the House of Lords now feels free to disregard its own decisions in the appropriate case, ${ }^{176}$ so that even its decisions are not conclusive proof of what is English law. Still less then are the decisions of lower English courts. An English decision therefore does not prove conclusively what English law is or was, for it may be overruled someday by a higher court which will say the lower court's decision never correctly represented what was the law of England at any time.

That being so, it is possible to reject a cut-off date for the reception of the common law as Park advocates. But it is not necessary to do so. Indeed, no one can deny that the common law does change and develop. Some new developments seem just to be an unfolding and elaboration of earlier doctrines and a drawing of corollaries, while other developments are a rejection of outmoded doctrines, largely because of changing moral and social views. The rise and fall of fault in torts, for better or worse, is an example. Therefore, neither the Park nor the Allott view can be rejected out of hand.

But Park ${ }^{177}$ does seem to prevail with two cogent arguments: an appeal to convenience, and an appeal to authority. In the first place, he says that it would be madness to assert one's freedom to dissent from modern English decisions (as clearly one may) only to insist upon the shackles of all the older cases before the cut-off date, presumably going back to the time of Bracton and the Year Books. Secondly, in practice the courts never apply a cut-off date to the common law.178 English decisions, however recent, are applied indiscriminantly all over the Commonwealth. One can open any volume of Australian or Canadian law reports and verify this in a moment. And the Privy Council has often applied as colonial law recent developments in the English common law which have arisen long after the date as of which the colony received its English law. ${ }^{179}$ Castles $^{180}$ also points out that South Australian or Western statutes seem to confirm this view. There is some American authority to the same effect. ${ }^{181}$

Allott's strongest argument is an appeal to logic, but even it is not conclusive. ${ }^{182}$ He says that the judges make law and so the common law changes just as much as statute law does, so the law of England as of 1792 , or 1824 , or 1840 , or 1870 , or 1900 , is not the same as English law today. Therefore the cut-off date is relevant. But the modern view that

i7s Lux v. Haggin (1886) 10 Pac. 674 at 750 (Cal.).

176 Note, [1966] 3 All E.R. 77.

17 Park, supra, n. 172 at 20-25.

176 To the same effect on this point and on the debate generally, see Bennion, Constitutional Law of Ghana 393.94 (1962).

178 Park points out, for instance, that in United Africa Co. v. Saka Owoade [1955] A.C. 130 the Privy Council applied the doctrine of Lloyd v. Grace, Smith \& Co. [1912] A.C. 716 to Nigeria, though that decision (a great novelty in 1912) was given after Nigeria's cut-off date for English law, which was 1900.

tho Supra, n. 154 at 7.

1w1 Chilcott v. Hart (1896) 45 Pac. 391 at 397 (S.C. Colo.).

182 Support for Allott may be found in Langelier v. Giroux (1932) 52 B.K. 113 at 116 ff. (Que.), and $R$. v. Chavendra [1939] S.Rhod. 218 at 225. 
judges make the common law out of thin air is no more accurate than the old idea that they only discover what has always existed. Indeed, it is probable that over 90 per cent of even the reported cases only apply well-settled rules to slightly novel fact situations. The old rules are thus elaborated and expounded more than they are abrogated or ignored. ${ }^{183}$

Therefore, the best answer is the middle view. Admittedly the common law develops, but it is its living growing body which was transplanted to the various Commonwealth territories, and not a petrified version of it. As one Canadian judge said, "I do not agree that the common law is any more static in British Columbia than in England."184 The American view is patently the same. ${ }^{185}$

Therefore, one should even look askance at any interpretation of a local statute introducing English law which would impose a cut-off date on the common law. Unless there are clear words imposing a cut-off date, the statute should be interpreted as only confirming the commonlaw rule of reception outlined above. Indeed, in view of the arguments just adduced it is not at all clear how one would go about applying a cutoff date to the common law.

Of course it might be otherwise where what was in question was not the common law proper, but a mercantile custom. ${ }^{186}$

\section{B. What Special Parts of English Law are in Force}

\section{(1) Equity}

A priori, one would simply assume that equity was an integral part of English law and therefore introduced as part of the general reception of English law. ${ }^{187}$ In fact, very few authorities question this view. ${ }^{188}$ The only unusual feature of colonial equity was that it was often administered, not by judges, but by the Governor, ${ }^{189}$ though some colonies got courts of chancery at quite an early date. ${ }^{190}$

The one jurisdiction where there seems to have been some difficulty was Upper Canada (now Ontario). It was part of a conquered colony, but a local statute ${ }^{191}$ provided that matters of property and civil rights were to be governed by "the laws of England." For want of express grant of equitable jurisdiction, the local courts seem to have taken this to refer only to the rules of the courts of law, but not those of equity. For some forty years the province struggled along with absolutely no rules of equity, with what injustice one can well imagine. ${ }^{192}$ This incredible state

is Re Lotzkar (1963) 40 D.L.R. (2d) 843 at 852 (B.C.S.C.); on appeal on other grounds 50 D.L.R. (2d) 338 and [1966] S.C.R. 69.

ins $R$. v. Carriere (1955) 17 W.W.R. (N.S.) 317 at 322 (B.C.S.C.); R. v. Goseb, supra, n. 171 at 699 is to the same effect, as are Stott v. Raby [1934] 3 W.W.R. 625 (reversed at 630 on other grounds), and Re Lotzkar, id.; Fleming v. Fleming [1934] O.R. 588 at 522; Castles, supra, n. 154 at 6-7; Central African Airways v. Vickers-Armstrong Ltd. [1956] 2 S.A. 492 at 493-94; Kerr, The Reception and Codification of Systems of Law in Southern Africa [1958] J. Afr. Law 832 at $86-87$.

14s Chafee, (1947) 57 Harv. L. Rev. 399 at 410; Pope, supra, n. 172 at 16-25.

inti O'Keefe \& Lynch of Canada Ltd. v. Toronto Ins. and Vessel Agency Lid. [1926] 4 D.L.R. 477 (Ont. S.C.).

16: 11 Am. Jur. 165, Common Law $\$ 9$.

ins Cf. Chafee, supra, n. 185 at 411.

169 Infra, n. 200.

190 Woodruff, Chancery in Massachusetts (1889) 5 L.Q.R. 370; Surrency, infra, n. 206 at 271.74 and 362; Wilson, Courts of Chancery in the American Colonies (1884) $18 \mathrm{Am}$. L. Rev. 226, reprinted in 2 Select Essays in AngloAmerican Legal History 779.

191 (U.C.) (1792) 32 Geo. 3, c. 1, 8. 3, now R.S.O. 1960, c. 310.

192 Falconbridge (1914) 63 U. Pa. L. Rev, 1, reprinted (1914) 34 Can. L.T. 1130; and see two articles by Dr. Riddell, in 40 Can. L.T. 802 and 41 Can. L.T. 740. 
of affairs continued until another local statute ${ }^{193}$ provided for a court of Chancery.

This would be nothing more than an antiquarian curiosity now were it not for the fact that the late Dr. Falconbridge, an eminent authority in several fields, has suggested ${ }^{194}$ that similar rules apply everywhere, apparently even in settled colonies. He contends that a general reception of English law did not include equity, and that it would be introduced only by a statute which either established a court of equity or (like the English Judicature Acts ${ }^{195}$ ) gave the powers of courts of equity to the ordinary courts. ${ }^{196}$ Of course for most purposes the practical results of this view are nil but this is not always so. A local statute might not happen to mention Chancery or equity when defining the powers of local courts, and the date of first enactment of legislation relating to equity might be different from that for the general reception of English law. That might be thought to mean the cut-off date for English statutes would depend upon whether or not they dealt with equity.

The simple answer to this seems to be that Dr. Falconbridge's theory is wrong, and equity is an integral part of English law. In other words, the common-law rule of reception covers equity too, and statutes on reception should (whenever possible) be interpreted in the same way. There are a number of considerations which support this view. In the first place, even the Ontario experience does not seem to bear out Dr. Falconbridge's views, for the early Ontario decisions ${ }^{197}$ that the rules of equity were not in force appeared to turn at least as much on the fact the courts had not equitable powers as on the wording of the local statute introducing English law. In other words, it may well be that they recognized that equity was in principle one of the parts of the law introduced but that they felt it was for the time being dormant for want of machinery to implement it. ${ }^{198}$ The experience in American states which had no courts with equitable powers fully bears out this conclusion, for equitable rules began to be applied there as soon as federal courts, or state courts of equity, were established.199 And of course in the majority of territories there would never have been such a want of courts of equity. ${ }^{200}$ Secondly, whenever a statute is involved, "law of England" or even "laws" can readily be interpreted as referring to all the body of law, including equity. The contrary interpretation is unduly narrow and unnecessary and produces absurd results. ${ }^{201}$ Even a reference to "common law", even if it does not mean the whole body of English law (as it may well do), at most probably excludes only statutes. In the third place, local acts based on the English Judicature Acts are only intended to regulate the powers of courts: they

193 (U.C.) 7 Wm. 4, c. 2.

194 Falconbridge, Banking and Bills of Exchange 426 (6th ed. 1956).

19: (Imp.) 36 \& 37 Vict., c. 66; 38 \& 39 Vict., c. 77.).

${ }_{19}$ As is the case almost everywhere, except in New South Wales.

${ }^{197}$ See a later case, Simpson v. Smyth (1846) 1 U.C. E. \& A. 9 at 57, 59.

19* This rule is discussed infra, p. 72.

1 y 1 Bishop. Commentaries on the Law of Marriage and Divorce $\$ 99,70$ (6th ed. 1881).

"No Supra, n. 190. And in most colonies, the Governor was by prerogative instrument made the Chancellor and acted as such, even though he was not a lawyer. See for instance Clark, A Summary of Colonial Law $31-32$ (1834), and Chitty, infra, n. 225 at 36; Townsend, History of the Court of Chancery in Nova Scotia (1901) 20 Can. LT. 14 at 37, 74, 105; Riddell, Early Proposals for a Court of Chancery in Upper Canada (1921) 41 Can. LT. 740 at 742; Simpson v. Smyth, supra, n. 197 at 66; Wilson, supra, n. 190 at 793 ff. (Select Essays); Surrency, infra, n. 206 at $271 \cdot 74$.

201 Martin v. Superior Court (1917) 168 Pac. 135 at 136-37 (Cal.); Soud v. Hike (1952) 56 So. 2d 462; Continental Guaranty Corp. v. People's Bus Line (Del. 1922) 117 Atl. 275 at 279. 
govern which court is to hear a suit, not what rules it is to apply. After all, these acts are modelled on the English Judicature Acts and often copy their wording closely: but the English Acts plainly were not intended to introduce equity into England! Finally, courts all over the common-law world have assumed all along that equity was part of the English law introduced, and acted accordingly without distinction between rules of law or equity, or statutes on legal or equitable topics. ${ }^{202}$

\section{(2) Ecclesiastical Law}

Before we plunge into a discussion of this topic we must remember that before 1857 certain topics which we now think of as ordinary matters of general secular law were handled in England only by the ecclesiastical courts. Notable among these were suits for probate, or nullity of marriage. It is unthinkable that such matters should not be part of the ordinary law received. ${ }^{203}$ The few authorities who have considered the question agree with this, ${ }^{204}$ and in practice the courts continually apply such rules and statutes without giving this problem a thought.205 Indeed, in most older colonies the Governor acted as Ordinary and administered some ecclesiastical law. ${ }^{206}$

What then of the parts of ecclesiastical law which applied to purely religious and episcopal matters such as doctrine, sacraments, church discipline, heresy, preferments and benefices, church decoration, and the like? We tend to forget how like England the First Empire was, especially in North America, where there were feudal dues and tithes, in some cases apparently even after the American Revolution. Thus in the Seventeenth and Eighteenth Centuries, the Church of England seems to have been established in the colonies, ${ }^{207}$ so its laws may well have been enforced there too. ${ }^{208}$ But whatever the historical truth may be, the courts have held otherwise in later years.

In the middle of the Nineteenth Century, Queen Victoria tried to exercise her prerogative to present to a benefice made vacant by the appointment of the incumbent to a bishopric. She would have had a clear right to do so had the bishopric not been in New Zealand, but in 1857 the English Court of Queen's Bench held ${ }^{209}$ that her claim failed. Lord Campbell C.J. for the court pointed out ${ }^{210}$ that English and Irish bishops were part of an established Church with their own "jurisdiction and important rights and privileges, both spiritual and secular." A bishop in New Zealand had very little in common with them. The Court thought the prerogative allowed the Queen to name Anglican bishops in settled colonies (where not forbidden by statute), but there being no established churches in colonies such bishops would have no more

\footnotetext{
202 Townsend, supra, n. 200; 15 C.J.S. 614 (\$ 13) at 616 (\$ 9); Whitby v. Liscombe (1875) 23 Grant Ch. 1 at 14.

${ }_{203}$ Dale, Adoption of the Common Law by the American Colonies (1882) 30 Am. Law Reg. 553 at $562-63$.

206 1 Bishop, supra, n. 199, $\$$ 71-76; Bursey v. Bursey (1966) 58 D.L.R. (2d) 451 at 457.58 (Nfld. S.C.); Green v. Green (1963) 49 M.P.R. 315; Re Seidler and Mackie [1929] 2 W.W.R. 645 (Alta. S.C.); Crump v. Morgan (1843) 38 N.C. 91 at 98.99. A dormancy theory is advanced in Gloth v. Gloth (1930) 153 S.E. 879 at 888 (Va.). Of course it is otherwise with the rules of practice, Bateman v. Bateman (1965) 50 D.L.R. (2d) 751 at 756 (Alta. S.C.)

zos 1 Bishop, supra, n. 199, $\$ 77$; cf. Chafee, supra, n. 185 at 411 . But as to who has property in a corpse, cf. Miner v. C.P.R. (1910) 15 W.L.R. 161 at 167.9 (Alta.).

206 Clark, supra, n. 200 at 32, 59; Chitty, infra, n. 225 at 36; Surrency, The Courts in the American Colonies (1967) 11 Am. J. Leg. Hist. 276 and 347, at 363.

${ }^{207}$ Keith, The First British Empire 222-28 (1930); Ex p. Jenkins (1868) L.R. 2 P.C. 258 at 270-71; cf. Clark, supra, n. 200 at 32n; and $c f$. Instructions to the Governor of Newfoundland in 1832: Cons. Stat. Nfld. 1916, vol. 1 pp. xxvi ff; and Surrency, supra, $n$. 206.

20n Pawlet v. Clark (1815) 13 U.S. 292 at 334-35.

$20 y$ R. v. Eaton College (1857) 8 E. \& B. 610, 120 E.R. 228 (Q.B.).

210 Id. at 237 (E. \& B.), 635 (E.R.).
} 
powers than the officers of any other religion. India and Jamaica were different because special statutes covered the matter there.

This decision was followed four years later in New South Wales, where the Supreme Court issued a writ of prohibition to restrain a bishop from exercising the ecclesiastical power to discipline one of his clergymen. ${ }^{211}$ But the Lord Bishop of Natal seems not to have known of these developments, for about this time he attempted to do what the Bishop of Sydney had done, and met the same fate at the hands of the Privy Council. That body said ${ }^{212}$ that though Natal was a settled colony, once there was a legislature the Crown could not legislate by the prerogative, and in the colony the Church of England was just one more voluntary association. Lord Chelmsford L.C. added:

It is a settled constitutional principle or rule of law, that although the Crown may by its Prerogative establish Courts to proceed according to the Common Law, yet that it cannot create any new Court to administer any other law; and it is laid down by Lord Coke in the 4th Institute, that the erection of a new Court with a new jurisdiction cannot be without an Act of Parliament.

It cannot be said that any Ecclesiastical Tribunal or jurisdiction is required in any Colony or Settlement where there is no Established Church, and in the case of a Settled Colony the Ecclesiastical Law of England cannot, for the same reason, be treated as part of the law which the settlers carried with them from the mother country.

Of course the Church of England, like any other church, is a voluntary association holding its property on certain trusts, and breach of these trusts will be restrained as such, not as enforcement of law with its own compelling force. ${ }^{213}$

That the bulk of ecclesiastical law is not received in the colonies may have repercussions in other areas of the law. Whether laws as to supersitutious uses, religious tolerance, dissenters and Jesuits, and so forth, are in force is for convenience best considered below ${ }^{214}$ as an aspect of what laws are "applicable" and what laws are not in force because unsuitable.

\section{(3) Statutes}

In general, there appears to be no general distinction between the reception of statutes and of common-law rules. All that matters is whether the statute was in force in England on the relevant date. Presumably the statute would have to have been in force in almost all of England,215 and indeed by statute many African territories have received only "statutes of general application".216 It is of course not enough that a statute have been in force only in Ireland or Scotland, and conversely (as we saw above ${ }^{217}$ ) the fact it was not in force there is irrelevant so long as it was in force in England.

Curiously enough, no one seems to have paid much attention to whether legislation other than Acts of Parliament could be in force in the colonies. Could valid legislation under the prerogative, or subor-

\footnotetext{
211 Ex p. King (1861) 2 Legge 1307.

21: Re Lord Bishop of Natal (1865) 3 Moo. P.C. (N.S.) 115 at 148, 151-53; 16 E.R. 43 at 56, 57.

2t. Wylde v. A.G. N.S.W. (1948) 78 C.L.R. 224 at 262 . Presumably that is all that the courts meant to say in Bishop of Natal v. Gladstone (1866) L.R. 3 Eq. 1 at 33 ff., and in Bishop of Columbia v. Cridge (1874) 1 B.C.R. (pt. 1) 5, though it is difficult to be sure of this. Long v. Bishop of Cape Town (1863) 1 Moo. P.C. (N.S.) 411 at 461 .62, 15 E.R. 756 at 774.75 , bases it on contract and arbitration.

214 Infra, p. 80.

215 This is discussed below more fully under Applicability; infra, p. 79.

216 See Park, supra, n. 154 at 27.

21: Supra, p. 32.
} 
dinate legislation by delegated authority under an Act, be received? The only authority on point is Reynolds v. Vaughan, ${ }^{218}$ where a trial judge held that an English Order in Council extending 19 \& 20 Vict., c. 108 to the County Court Act could not be in force in British Columbia, whether proprio vigore, or as law introduced as the law of England. The local "English Law Ordinance" was held to introduce only the common law and statutes. This seems to be a sensible decision, though it is difficult to find any particular rule of law on which to base it. It is difficult enough for lawyers outside England to acquire and familiarize themselves with all the relevant English Acts, without having to look for statutory instruments, and this may be as good a reason as any.

\section{(4) Constitutional Law}

We noted above ${ }^{219}$ that British constitutional law is in force in conquered colonies, and if this is so, it must be true $a$ foritori in settled colonies. 220

In a federal state, this matter of constitutional law is a little more complicated. Different cases express the result by means of different metaphors, but there seems to be substantial agreement as to the result. Each colony, each province or state, and each federation received the ordinary constitutional rights and duties of Crown and subject. In this sense, there is a parallel between the Crown in the right of the federation, and the Crown in the right of the individual state or province in the federation. ${ }^{221}$ But this cannot apply to all matters, for legislative competence and property are distributed between the federation on the one hand, and its several members on the other. Therefore, the Crown's rights undergo a similar distribution and the Crown in each right receives the prerogatives and duties appropriate to its property and legislative competence. ${ }^{222}$

Though there is some dispute, ${ }^{223}$ the better view is that a settled colony receives all the royal prerogatives, including those not essential to sovereignty 224 (except of course those not applicable to the circumstances of the colony).

\section{(5) Admiralty Law}

In origin this was quite distinct from the common law, which was indigenous in origin, and the law of the realm: Admiralty law was neither. Admiralty law regulated matters occurring outside the realm, ${ }^{225}$ and it was very similar to the maritime law of many European nations, having origins going back to the laws of Oleron and Rhodes. It was even

\footnotetext{
210 (1872) 1 B.C.R. (pt. 1) 3.

219 Supra, p. 40.

220 Kielly v. Carson (1842) 4 Moo. P.C. 63 at 85, 13 E.R. 225 at 233 (P.C.) (Nfld.); Re Bateman's Trust (1873) L.R. 15 Eq. 355 at $361 ; R$. v. Kidman (1915) 20 C.L.R. 425 at 445, quoting. Western Union v. Call Publishing Co. (1901) 181 U.S. 92 at 101 , holds that in a federal state for the purpose of ordinary federal laws there is also a common law in force, though it apparently is the common law in force in whatever state or province the matter arises. But for constitutional matters, this is not so: the Kidman case, at 435, 536. To the same effect as the Western Union case is Erie R.R. v. Tompkins (1938) 304 U.S. 64.

On the general question of the prerogative as part of the common law, cf. Nyali Led. v. A.-G. [1956] 1 Q.B. 1 at 16 (C.A.).

221 R. v. Kidman, id at 435-36.

222 Liquidators of the Maritime Bank of Canada v. Receiver.General of New Brunswick [1892] A.C. 437 (P.C.); A.-G. B.C. v. A.-G. Canada (1889) 14 App. Cas. 295 at 302.

223 Roberts-Wray, Commonwealth and Colonial Law $558-59$ (1966).

224 Chitty, A Treatise on the Law of the Prerogatives of the Crown 32-33, especially the last few lines on 32 and 33 at note (i): Liquidators of the Maritime Bank of Canada v. Receiver General of New Brunswick, supra, n. 222 at 441; and cf. A.-G. B.C. v. A.-G. Can., supra, n. 222.

22s $R$. v. Keyn (1876) 2 Ex.D. 63, and see also Reference re Offshore Minerals 65 D.L.R. (2d) 353.
} 
administered in England by a separate court. Nevertheless, there seems to be no reason why one could not call it part of the law of England, and still less reason why it should not apply equally to the colonies. This seems in fact to have been the practice, there being vice-admiralty courts in many colonies, ${ }^{226}$ and the grant in 1891 of the powers of a court of admiralty to the ordinary colonial courts ${ }^{227}$ merely confirms this.

\section{(6) The Law Merchant}

This was also at one time an "international" law not confined to England, but it is now universally recognized ${ }^{228}$ to have become part of the common law of England centuries ago. Therefore it must also be received in the colonies. ${ }^{229}$ Indeed, some local statutes, such as the various Sale of Goods Acts, refer to its being so received. ${ }^{230}$

\section{(7) Practice and Procedure}

One cannot deny that colonial courts have often followed English courts' decisions on practice and procedure, ${ }^{231}$ and some jurisdictions have statutes or rules of court expressly making English procedure applicable. ${ }^{232}$ But on the other hand, following English decisions is probably more a matter of convenience than one of law, and there is some authority to the effect that a general reception of English law does not include the practice and procedure of the English courts. ${ }^{233}$ Indeed, some jurisdictions have rules providing that matters not covered are to be governed by analogy, and that has been held to exclude the applicability of English practice. ${ }^{234}$

It is also interesting that the practice and procedure of legislative assemblies is not automatically received either. ${ }^{235}$

\section{THE GENERAL RULES OF APPLICABILITY}

\section{A. Introduction}

In the previous chapters, we have discussed which parts of English law are received in principle. But as we saw above, ${ }^{236}$ in a settled colony the rules of English law are received only to the extent that they are

228 Cf. Chafee, supra, n. 185 at 411; Chitty, supra, n. 224 at 36; Clark, supra, n. 200 at 33, 59-61; Surrency, supra, n. 206 at 353-60; Smith, Appeals to the Privy Council 514-20 (1950). Indeed, there were even published reports of Admiralty decisions in some North American colonies. One Eighteenth Century Attorney General based this jurisdiction on a phrase in $22 \& 23$ Car. 2, c. 26: Forsyth, Cases and Opinions on Constitutional Law $91-92$ (1869).

227 (Imp.) 53 \& 54 Vict., c. 27, s. 2, which came into force in most areas on July 1, 1891.

22s Piatt v. Eads (1820) 1 Blackf. 81 (Indiana); Cook v. Renick (1858) 19 Ill. 598 at 602.

229 See note, Ann.Cas. 1913E 1228-29. New York and South Carolina even had courts of pie-powder! Surrency, supra, n. 206 at 352-53.

2so This is undoubtedly because the wording of the English Act has been copied. see, for instance, R.S.O. 1960, C. 358, 8. 57(1).

231 Infra, p. 76.

2.12 As to forms, for instance, see Saskatchewan Queen's Bench Rules, r. 2. And as to the Exchequer Court of Canada, see Muzak Corp. v. C.A.P.A.C. [1953] 2 S.C.R. 182. But in others, the provision is the contrary: see infra, n. 234.

z:a Hauer v. Hauer (1956) 20 W.W.R. 89 at 90 (Sask.), quoting May v. May [1934] 3 W.W.R. 471 at 474 (Sask. C.A.), though these cases may turn on local legislation. Augustino v. Can. N.W. Ry. [1928] 1 W.W.R. 481 (Alta. C.A.) does turn on such legislation but clearly recognizes the distinction in the text. CF. $R$. v. Connor (1885) 1 Terr. L.R. 4 at 12 (C.A.), 2 Man. R. 235 (grand jury not received); Sydney Smith J.A. dissenting in Densmore v. Densmore (1956) 19 W.W.R. 252, the majority there being reversed in [1957] S.C.R. 768, sub. nom. Hellens v. Densmore; Morris v. Morris [1951] 1 D.L.R. 38 at 46, 47 (H.C.); Adler v. Adler [1965] 2 O.R. 707; Bateman v. Bateman, supra, n. 204. CF. R. v. Tymchyshyn (1965) 54 W.W.R. 624 at 629 (Alta. D.C.). Contra, Leclerc v. Leclerc (1964) 45 D.L.R. (2d) 770 (Man. Q.B.).

2:34 Kemp v. Beattie [1929] 1 D.L.R. 55 at 57 (Ont. S.C.); Alberta is in the same position: compare 1944 C.R. 3 with the former C.O. N.W.T. 1905 c. 21 s. 3 , and see the Augustino case, id.

2.3s Kielly v. Carson, supra, n. 220 at 90 (Moore), 235 (E.R.).

200 Supra, p. 48. 
suited to the circumstances of the colony. And as we also noted, statutes introducing English law usually contain some such provision, ${ }^{237}$ or if they do not, are interpreted as implying such a proviso. ${ }^{238}$ In other words, a rule of English law or statute which fulfills all the general tests for reception, and would otherwise be in force in the colony because it was part of the law of England on the relevant date, may in fact not be in force simply because it is not apt for use in the colony. We must now consider these matters in detail.

We speak of "suitability" or aptness here, for it is this question, and not whether the statute or rule is capable of being applied in the colony, which is in issue here. ${ }^{239}$

Indeed, the consequences of rules not being suitable, or "not applicable" (as the authorities often say) is not limited to the rules not being in force. In certain circumstances, a rule or statute may be in force, but with modifications calculated to adapt it to the circumstances of the colony. ${ }^{240}$ Sometimes this adaptation merely entails the omission of some minor parts of the rule or statute, ${ }^{241}$ but it can mean more than that. It may entail actual changes in some rules, or rules which are the very reverse of the English rule. ${ }^{242}$ Many African statutes give the courts express power to effect such modifications. ${ }^{243}$ This being so, one may view with some reservations the statement in one Nova Scotia decision ${ }^{244}$ that the colony's circumstances may circumscribe or exclude an English rule but they cannot enlarge its ambit; indeed that is contrary to a recent Privy Council decision enlarging the scope of the doctrine of laches in West Africa. ${ }^{245}$

There are dicta in some African cases suggesting that unsuitability and consequent non-application of English law may be found and applied in individual cases. ${ }^{246}$ This is very questionable, and runs contrary to the rest of the authorities which assume that the law is the same for everyone and that a given English rule (or part of a statute) binds everyone in the colony or no one.

\section{B. The Right Time to Test Applicability}

(1) The Time in England

As of what date do we have to look at England to see whether a rule of law, or statute, is suitable to the colony? No date after the cut-off date will do, for any change in law or social conditions in England after the date as of which English law is received is by definition irrelevant. Of course it might have some indirect relevance as evidence of unsuitabili-

237 Supra, p. 49.

238 Supra, p. 50, a suggestion that there is some difference between a limitation to suitable law and a double negative to the same effect made in S. v. S. (1877) 1 B.C.R. (pt. 1) 25 at 49 seems doubtful.

239 Quan Yick v. Hinds (1905) 2 C.L.R. 345 at 354, citing Whicker v. Hume (1858) 7 H.L.C. 124, 11 E.R. 50; Miller Morse Hardware Co. v. Smart [1917] 3 W.W.R. 1113 at 1117 (Sask. C.A.).

240 Hanington v. McFadden (1836) 2 N.B.R. 260 at 283; the discussion on the substitution of local machinery for English machinery, infra, at nn. 302, 310 .

241 Sheppard v. Sheppard (1908) 13 B.C.R. 486 at 511-12, and cases there cited.

242 Allott, Essays in African Law 25, 42 (1960); G. v. C. [1951] 3 D.L.R. 138 at 145 (B.C.S.C.); Sidney Smith J.A. dissenting in Densmore v. Densmore (1956) 19 W.W.R. 252 at 259, the majority being reversed sub. nom. Hellens v. Densmore [1957] S.C.R. 168. Accord, Jex v. McKinney (1889) 14 App.Cas. 77 at 81 (P.C.), though this may have turned on a local statute. It refers to "some amount of moulding in formal or insignificant dedails.' $C$. Quan Yick v. Hinds, supra, n. 239 at $359-60$; Barton J. at $370-71$ is plainly in agreement Bamgbose v. Daniel [1955] A.C. 107 (P.C.) (W.A.). The case going the furthest seems to be Maleksultan v. Sherali Jerai [1957] J. Afr. L. 58 (E.A.C.A)

243 Allott, id. at 24; but Bamgbose v. Daniel, id., does not tum on any such provision.

24. Freeman v. Morton (1856/59) 3 N.S.R. 340 at 352

245 Nana Ofori Atta II v. Nana Abu Bonsra II [1958] A.C. 95 at 103 (P.C.) (G.C.).

246 Allott, supra, n. 242 at 22; Morris and Read, infra n. 259. 
ty. For instance, evidence that some change in recent social conditions led to repeal of an old statute, might support an argument that the statute was not suitable to the colony where the new social conditions prevail. But that is another matter.

Therefore, the choice is restricted to two possible dates:

(a) The date the English rule arose in England, or the date on which the English statute came into force in England; or

(b) The date as of which English law is selected for the colony (the "cut-off" date).

Many English rules of law and statutes are very old, and their origins are either shrouded in mystery or lie in social and political conditions very different from any which have prevailed in any colony in the last century or two. Therefore, if date (a) is chosen a number of rules and statutes will very likely be held to be unsuitable because they were evolved or enacted to solve problems long since gone and thus of no relevance in the colony. But if (b) is chosen, many of these rules and statutes will be held suitable because England at the cut-off date was not significantly different from the colony.

One might rephrase the problem as being whether we look to the origins of the English rule, or the reasons for its retention.

The courts in Alberta have apparently taken a stand on this question in $R e$ Simpson Estate ${ }^{248}$ and Re Budd Estate, ${ }^{249}$ even though the contrary proposition was not discussed. Both cases held that the rule in Shelley's Case was not in force in Alberta because it had been evolved long ago in England to meet the needs of a feudal society. As Alberta had never been a feudal society, the same reasons for introducing such a rule did not exist. There is a good deal of force in this argument, and in many cases it will produce a result with which no one could quarrel. But although there is some authority to support this view, 250 it is submitted that the contrary view is preferable. Indeed, the Simpson rule ${ }^{251}$ has recently been considered and rejected by Turner $J$. in the New Zealand Court of Appeal. ${ }^{252}$

The Simpson rule does point up the danger of export from England of rules and statutes which have been mere deadwood for centuries, having long outlived the conditions which gave them birth, and possibly even been forgotten in practice or repealed by a Statute Law Revision Act since the "cut-off" date for the reception of English law. But the contrary rule, testing applicability as of the "cut-off" date, could yield the same result. The two theories need differ in result only in the case of an English statute or rule which was introduced some time ago for reasons long since irrelevant to modern society, but was retained in modern England for very different reasons. Prime examples are the Statute of

207 This section is based in part upon a passage in the author's article in (1964) 3 Alta. L. Rev. 262 at $267-71$.

24s [1927] 3 W.W.R. 534 (Alta. C.A.), affirmed on other grounds, [1928] S.C.R. 329. It is interesting to compare this decision with Doyle v. Andis (1905) 102 N.W. 177 (Iowa).

268 (1958) 24 W.W.R. 383 (Alta. S.C.).

250 A.G. v. Stewart (1817) 2 Mer. 143 at 161, 35 E.R. 895 at 900-01. Cf. A. G. Vict. v. Moses [1907] V.L.R. 130 at 141 (C.A.), and Coondo v. Mookerjee (1876) 2 App.Cas. 186 at 208-09 (P.C.). Whether Nelan v. Downes (1917) 23 C.LR. 546 at 550-51 supports this view is doubtful, but $R$. v. Valentine (1871) 10 N.S.W.S.C.R. 113 at $121-22$ does, and 80 apparently does Jolly v. Smith (1899) 1 N. \& S. 143 at 150 (Tas. C.A.). CF. Lawal v. Younan [1961] 1 All Nig. L.R. 245 at 256 (Fed. Sup. Ct.), per Brett F.J., and Rand J. in A.G. Alta. v. Huggard Assets Ltd. [1951] S.C.R 427 at 442 (reversed on other grounds [1953] A.C. 420 (P.C.).

251 As applied more recently in a dissenting judgment of Porter J.A. in Re Burns Estate (1961) 25 D.L.R. (2d) 427 (Alta. C.A.).

${ }^{232}$ Re Lushington [1964] N.Z.L.R. 161 at 175. 
Uses and the statute Quia Emptores. They were introduced centuries ago for reasons of the moment long since past, but now serve important technical functions in property law. ${ }^{253}$ They are so deeply imbedded in its structure that one could not pull them out without endangering the whole structure.

The view expressed by the New Zealand judge permits us to see whether or not the English statute was mere deadwood or an anachronism at the cut-off date, but the Simpson view will not even permit us to ask this question.

Indeed there is an even greater danger in the Simpson rule. One of the most effective tricks of legal polemics is to invent a narrow origin or "rationale" for a legal rule which one wishes to abolish. Then all one need do is to illustrate that the rationale rarely applies or has disappeared. Critics of the hearsay rule in evidence, for instance, often suggest that it exists only to guard against the foibles of juries, and that as juries tend to disappear so should the hearsay rule. And many writers with little background in legal history (or any other kind of history) like to emulate Charles and Mary Beard in finding adventitious and economic motives for all manner of legal innovations in the past. Debate about Rylands v. Fletcher, and about the role of fault in torts, are studded with such speculations. When the applicability of a somewhat more obscure rule of law or statute was an issue, the Simpson rule would leave the court defenceless against such tactics. The only thing relevant would be what Holdsworth (or some less reputable writer) said was the origin of the rule, and the fact that the rule had seemed just and convenient and well known in England up to the present day would be formally excluded from consideration.

This controversy becomes even more important if one takes the view (discussed below) that one tests applicability in the colony as of the "cutoff' date, for then one uses the same date for England and the colony and social conditions in the two places were probably almost identical then. Even if one looks at the present day in the "colony", the physical and economic situation is probably much like England's at the "cut-off" date. In sum, only the Simpson theory would produce glaring disparities which would absolutely compel a court to reject a good many English rules.

\section{(2) The Time in the Colony}

Obviously there is no sense in looking at the situation of the colony when the English rule or statute came into being, for the colony likely was not even founded until long after. Therefore, we are here left with four real possibilities:

(a) the "cut-off" date as of which English law is received

(b) the date on which the statute (if any) introducing English law came into force

(c) the date on which the courts of the colony first considered the English rule's applicability

(d) the present date (or better still, ${ }^{254}$ the date at which the facts giving rise to the present lawsuit arose).

It is unlikely that (b) can be correct, for many colonies have no

25. Cf. Dubuc J. in Re Tait (1890) 9 Man. R. 617 at 618

2s4 Roberto-Wray. Commonwealth and Colonial Law 546 (1966). 
statute on the question, and mere codification should not change the law. Nor is it to be presumed that the accident of the date of passage of an Act has a crucial effect on the law. ${ }^{255}$ Lest it be thought that such statutes dictate a contrary result by their use of the present tense ("are applicable," or the like), many jurisdictions have a rule of construction that statutes are to be read as always speaking. ${ }^{256}$

Nor is there much sense in choosing (c). It would produce certainty, for choosing (d) might well imply that the law changes and that an English rule could drift into or out of force. But (c) is a poor choice, even if one does take the view that once a statute or rules is in force it stays in force (or if not in force at first, it never is). Why should the accident of the date of the first suit govern the matter? What if conditions in the colony were temporarily abnormal at the time of bringing the first suit? Furthermore, when the first suit was brought, time was at the present and the court therefore applied either (a) or (d). If it applied (d), it probably thought (if it thought logically) that applicability from time to time mattered: to freeze such a decision as the rule for all time, would gravely distort the court's decision. On the other hand, if the court applied (a), we can follow its decision and leave the law settled only by doing the same.

Therefore, the only real contest is between (a) and (d). Was all the law received that which was suitable at point (a), which was probably in the early days of the colony? Or do we decide questions of suitability from time to time and receive English rules and statutes as they become applicable? There would also be the problem of dropping them as they cease to be applicable, but for some reason this rarely seems to arise in practice. ${ }^{257}$ The strongest authority for (a) is Blackstone, ${ }^{258}$ who said:

Such colonists carry with them only so much of the English law as is applicable to their own situation and the condition of an infant colony.

This answer may therefore be conveniently referred to as the "infant colony" theory, and it has quite a body of authority in support of it. ${ }^{259}$ But there seem to be just as many authorities against this view and in favor of applicability from time to time, ${ }^{260}$ and the arguments for this latter view seem more compelling.

2ss But cf. Porter J.A., supra, n. 251 at 431.

250 E.g. Canada: R.S.C. 1970, c. 1.23, 8. 10; New Zealand: Acts Interpretation Act, 1924, 8. 5(d). Cf. Johnston v. Johnston [1942) O.W.N. 47 at 48 (using such a provision for a different purpose).

${ }^{257}$ Cf. Travis.Barker v. Reed [1921] W.W.R. 770 at 780 (Alta. C.A.); reversed on this point [1923] 3 D.L.R. 927 at 930 (S.C.C.); and Bilby v. Hartley (1892) 4 QId. L.J. 137 at 144, per Lilley C.J. Such subsequent inapplicability was found in Re Dunsmuir's Will (1968) 63 W.W.R. 321 at $341-42$ (B.C.S.C.).

25s 1 Bl. Comm. 107.

259 Quan Yick v. Hinds, supra, n. 239 at 356, 367, 368, 378; Mitchell v. Scales (1907) 5 C.LR. 405; cf. Mayor of Lyons v. East India $C_{0}$. (1836) 1 Moo. P.C. 175 at 276-77, 12 E.R. 782 at 819; Ex parte Lyons (1939) Legge 140, per Stephen J. at 152-53; cf. Uniacke v. Dickson (1848) 2 N.S.R. 287 at 291, per Halliburton C.J.; $R$. v. Valentine, supra, n. 250 at 121; Brett v. Young (1882) 1 S.C. (N.Z.C.A.) 262 at 264; cf. Wallace v. King (1887) 20 N.S.R. 283 at 289 (C.A.); Bilby v. Hartley, supra, n. 257 at 144; Sheehy v. Edwards, Dunlop \& Co. (1897) 13 N.S.W.W.N. 166 at 168; R. v. DeBaun (1901) 3 W.A.L.R. 1 at 9 (C.A.); Plested v. McLeod (1910) 12 W.L.R. 700 at 702.03 (Sask. D.C.); a dictum of Martin J. in Re Hogbin Est. [1950] 1 W.W.R. 264 at 268 (B.C.); Morris and Read, Uganda: The Development of its Laws and Constitution 244 (1966); see the two Hong Kong decisions referred to by Magistrate Haydon in (1862) 11 I.C.L.Q. 231 at 235-38.

Castles (1963) 2 Adel. L. Rev. 1 at 89, 13, 16 accepts the infant colony rule for statutes but not common-law rules, but does not really explain why there should be a difference.

260 Fitzgerald v. Luck, (1839) Legge 119 at 120; Uniacke v. Dickson, id. at 300, per Hill J.; M'Hugh v. Robertson (1885) 11 V.L.R 410 (C.A.); Cooper v. Stuart (1889) 14 App.Cas. 286 at 293 (P.C.) (N.S.W.); Bilby v. Hartley, supra, n. 257, per Harding J. at 145, but of. 141; Delohery v. Permanent Trustee Co. (1964) i C.L.R. 283 at 289; Hellens v. Densmore [1957] S.C.R. 768 at 782-83, per Rand J.; Kennedy (1957) 2 U.B.C. Leg. N. 419 at $423 ;$ Lyle v. Richards (1823) 9 Serg. \& R. 22 at 330 (Pa.); Fares v. R. [1929] Ex.C.R. 144 at 151, rev'd. [1932] S.C.R. 78, but not as to this point: see 94; Haydon, supra, at 249-50. Jex v. McKinney (1889) 14 App. Cas. 77 at 81-82 (P.C.) is ambiguous, for the British Honduras than was still an infant colony. 
As for the quotation above from Blackstone, the Privy Council has said that it is a little misleading: ${ }^{261}$

Blackstone, in that passage was setting right an opinion attributed to Lord Holt, that all laws in force in England must apply to an infant colony of that kind. If the learned author had written at a later date he would probably have added, that, as the population, wealth and commerce of the colony increase, many rules and principles of English law, which were unsuitable to its infancy, will gradually be attracted to it: and that the power of remodelling its laws belongs also to the colonial legislature.

In that case, the Privy Council held that the fact a rule was applicable at the time of the suit did not mean it had been so 65 years before when the colony was new. Therefore, the passage above appears to be part of the ratio and so the highest possible Commonwealth authority against the infant colony theory. ${ }^{262}$

There is American authority to the same effect, for Story in his Commentaries on the Constitution of the United States ${ }^{263}$ wrote that the:

English rules of inheritance, and of protection from personal injuries, the rights secured by Magna Charta, and the remedial course in the administration of justice, are examples as clear perhaps as any which can be stated as presumptively adopted, or applicable. And yet in the infancy of a colony some of these very rights and privileges and rules may in fact be inapplicable, or inconvenient and impolitic.

This argument is very compelling; why should the amount and nature of the law received depend upon the accident of the modest beginnings of a colony? It would be a pity if a few years' delay in the selection of a cut-off date (say, until there was a local legislature) should totally change the nature of the law received. After all, some colonies have had extremely modest beginnings to which hardly any law would be suitable. The conclusion to which we are irresistibly drawn, therefore, is that while the infant colony may at first receive only rudimentary law, more and more law would come into force "with the increase of population and the general development of its political, social and economic life."264

\section{The Criteria of Applicability \\ (1) Preliminary}

One can detect varying degrees of receptiveness among different decisions of the courts on the suitability of various English rules. Indeed, a Nova Scotia decision, Uniacke v. Dickson ${ }^{265}$ suggests that common law rules are probably in force unless there is some reason to the contrary, while the opposite is true of English statutes. A reading of the cases will strongly confirm this view, although it is difficult to find any logical reason for it. But whatever the reason, courts rarely question the suitability of common-law rules, while English statutes are thought a rather novel and exotic intrusion. The answer may lie in the peculiar difficulty of consulting (or even finding references to) English statutes, as contrasted with English decisions. But even when English statutes are in question, some courts seem much more reluctant than others to receive them, and their supposed unsuitability is almost always the

281 Cooper v. Stuart, id. at 292.

362 Castles, supra, n. 259, suggests that Pictou v. Geldert [1893] A.C. 524 (P.C.) may also be authority to the same effect, though there is no explicit discussion of this point there.

265 Vol. 1, § 149, at $104-05$ (5th ed. 1891).

264 Rand J. in Hellens v. Densmore [1957] S.C.R. 768 at 782, a judgment supporting the views expressed in the text.

zos (1853) 2 N.S.R. 287. The same willingness to accept the common law is found in a case in Jamaica, Jacquet $v$. Edwards (1867) i S.C.J.B. 70, 1 Stephens S.C.D. 414 at 419 . It is also displayed in Fares v. R., supra, n. 260. 
reason adduced. Such a court may well require positive demonstration of why the English statute came into being and an indication of a similar evil in the local area. ${ }^{266}$ Where the social and physical conditions of the colony are quite different, this approach becomes very plausible.

But it is submitted that this approach can easily be pushed too far, and that it is better to approach the matter without any leaning for or against applicability. ${ }^{261}$ The Privy Council held a few years ago that the rules as to conditions in partial restraint of marriage were in force in Malaya, saying:268

It is not merely a rule of construction, since its history shows that it owes its existence to a particular conception of what public policy required even though that conception never prevailed in the English law as a whole. Yet there is nothing that is peculiar to the local conditions of England or, for all that appears, anything necessarily inappropriate to the circumstances of Malaya, in a reluctance on the part of courts of law to allow a person's decision whether or not to enter the state of matrimony to be overhung by a condition that forfeits his or her interest in property. . . .

This shows a willingness to approach general rules of English law with an open mind free from any presumption of inapplicability.

\section{(2) The Problem of Generality}

This mention of English conditions being peculiar, or Malayan conditions being unsuitable, leads to a theoretical distinction adverted to by some of the modern Australian writers. ${ }^{269}$ Is the question whether the English law and English conditions were peculiar or general, ${ }^{270}$ or is the question whether the colony and its circumstances are peculiar?271 Paton ${ }^{272}$ suggests that these two questions are really equivalent, at least in result, because the general run of laws are suitable even to a new colony, while the sort of artificial distinctions which would exist in England would not be suitable to a new colony. The trouble with this though, is that England and the colony could differ from the ordinary in the same way, or in different ways. The possibility of a number of rules covering the various permutations and combinations then arises.

\section{(3) The Proper Test}

But all this is needlessly complicated, for the applicability of an English rule to a colony only involves comparison of England and the colony, and the third element of what a generally suitable law would be is irrelevant. Therefore, one need only see why the law exists or existed

266 Leith v. Wills (1836) 5 U.C.Q.B.(O.S.) 101 at $102-03$

267 Cf. Ruddick v. Weathered (1889) 7 N.Z.L.R. 491.

28n Leong Ba Chai v. Lim Beng Chye [1955] A.C. 648 at 665 (P.C.); and cf. Brett F.J. in Lawal v. Younan, supra, n 250 at 255 , who suggested that inapplicability meant a case where enforcement of the English statute would entail "grave inconvenience". Cf. Walker v. Solomon (1890) 11 N.S.W.L.R. 88 at 104 (C.A.), and R. v. DeBaun, supra, n. 259 at 9-10, and Doe d. Hanington v. McFadden (1836) 2 N.B.R. 260 at 270, and Travis-Barker v. Reed [1928] 3 D.L.R. 927 (S.C.C.), and Nichols v. Anglo-Australian Investment Co. (1890) 11 N.S.W.L.R. 354.

${ }^{269}$ An unpublished doctoral dissertation by Dr. S. H. Z. Woinarski referred to by Paton, The British Commonwealth: The Development of its Laws and Constitutions: Australia 4 (1952).

270 A.G. v. Stewart, supra, n. 250 at $160-61$ (Mer.), 900 (E.R.), seems to support this former view, and this passage is quoted in Whicker v. Hume (1858) 7 H.L.C. 124 at $150-151,11$ E.R. 50 at 61. R. v. DeBaun, supra, n. 259, may be thought to support this view also, as may Jex v. McKinney, supra, n. 260 at 81 , and Delohery v. Permanent Trustee Co., supra, n. 260 at 310 .

Young v. Abina (1940) 6 W.A.C.A. 180 shows that this first view may be the rule in African territories whose statutes impose English statutes "of general application." Accord, Lawal v. Younan, supra, n. 150 at 256. Park, The Sources of Nigerian Law 25 points out that the phrase must mean general in England, and not general throughout the Commonwealth, for the judges in one colony cannot know that, and it would produce a vicious circle anyway. But (id. at 27) he says that it can be general in England for these purposes even though it is only for one type of court (even an inferior court) or for one class of the public.

271 Quan Yick v. Hinds, supra. n. 239 at 355, citing Jex v. McKinney, supra, n. 260, is clear authority ofr this second view.

272 Supra, n. 269. 
in England and what other effects it would have there and then see whether the same social or moral problems exist in the colony and whether the rule would have any other side effects in the colony. ${ }^{273}$

Of course this does not preclude reference to the decisions in other colonies as to the suitability of an English rule if the two colonies seem similar. ${ }^{274}$

But the general test enunciated above does not mean that an English statute enacted for needs and institutions peculiar to England and not found in the colony is applicable to the colony. Thus the Mortmain Act was held ${ }^{275}$ not to be in force in Grenada because:

In its causes, its objects, its provisions, its qualifications, and its exceptions, it is a law wholly English, calculated for purposes of local policy, complicated with local establishments, and incapable, without great incongruity in the effect, of being transferred as it stands into the code of any other country.

\section{(4) Conditions in the Colony}

When may the courts hold that English rules or statutes are inapplicable? Lord Denning said a few years ago that inapplicability should be liberally construed, for the common law:276

. . has many principles of manifest justice and good sense which can be applied with advantage to peoples of every race and colour all the world over; but it has also many refinements, subtleties and technicalities which are not suited to every folk. These offshoots must be cut away. In these far-off lands the people must have a law which they understand and which they will respect. The common law cannot fulfil this role except with considerable qualifications. The task of making these qualifications is understood to the judges of these lands. It is a great task. I trust they will not fail therein.

Stirring words. But one must remember that Lord Denning regards many well-settled rules of English law as "off-shoots [which] must be cut away", even for use in England. Then again, he was speaking in that case of the African scene, and there were clearly implicit in his judgment the social differences with which that entails; the words "in these far-off lands the people must have a law which they understand. . . " make this clear. Therefore, it is not safe to base too much on the passage above.

We noted above 277 that the courts should not hold common-law rules, or even statutes, to be inapplicable without tangible grounds for doing so. What are such tangible grounds? The Appellate Division in Alberta said some years ago that: 278

... where resort is to be had to the common law the applications of its principles do not necessarily result in the same decisions as have been or may be given by the English Courts, but that account must be taken of the different conditions prevailing in this country, not merely physical conditions but the general conditions of our public affairs and the general attitude of the community in regard to the particular matter in question.

Turning first to physical conditions, we find only a few decisions

273 In substance this seems to be the conclusion also reached by Castles, supra, n. 259 at 21. Cf. Allott, Essays in African Law 21 (1960), and Shaik Saheed v. Sockalingam [1933) A.C. 342, 102 L.J.P.C. 111 at 113 (P.C.).

${ }^{274}$ Delohery v. Permanent Trustee Co., supra, n. 260 at 313.

275 A.G. v. Stewart, supra, n. 250 at 163-64 (Mer.), 901 (E.R.). Cf. Syndicat Lyonnais v. McGrade (1905) 36 S.C.R. 251 at 271, and Mitchell v. Scales, supra, n. 259 at 410-11.

376 Nyali Ltd. v. A.G. [1956] 1 Q.B. 1 at 16 (C.A.), affirmed on other grounds, [1957] A.C. 253 (H.L.).

277 Supra, pp. 67.8.

278 Flewelling v. Johnston (1921) 16 Alta. L.R. 409 at 413-14, citing $R$. v. Cyr (1917) 12 Alta. L.R. 320, [1917] 3 W.W.R. 849 . 
turning on this. 279 In another Alberta decision, ${ }^{280}$ which held that clothes not actually in use were still exempt from seizure, the matter was reversed on appeal, where it was said that there was not sufficient difference in climate between Alberta and England to justify this refusal to apply English law. But it has been held ${ }^{281}$ that the English law as to flowing surface water is not suitable to a territory bordering on mountain ranges and covered by large tracts through which run many considerable streams. In like manner, some writers ${ }^{282}$ have speculated that the refusal of many American states to apply the rule in Rylands $\mathrm{v}$. Fletcher ${ }^{283}$ may be grounded on the aridity of those states, and there is some tangible evidence of this in the remarks of at least one Texas case $^{284}$ where it is stated that unlike Texas (where reservoirs are needed) England "is a pluvial country" (implying that reservoirs are a selfindulgence there).

There is more authority on race, religion, and social conditions. ${ }^{285}$ The best-known cases are those on marriage. The requirement that marriages must be performed by a clergymen to be valid has been dispensed with in situations where clergymen were few and distant,286 and with respect to non-Christian communities with other marriage customs.287 Then again, the general rule against recognition of polygamous marriages has been entirely waived in communities where this is common, ${ }^{288}$ and adjustments have been made in guardianship law. ${ }^{289}$

In like manner the law as to aliens was not in force in Bengal for the British courts were set up in times when there were very few British subjects in the area. ${ }^{290}$ And estoppel by res judicata and laches has been extended in its operation in West Africa because of the custom there of litigating land disputes between factions. ${ }^{291}$

It has never been clear whether the implied terms in particular contracts in English law rest on rules of law, or presumptions as to what the parties intend, and it is therefore interesting to note a Hong Kong decision ${ }^{292}$ to the effect that a Chinese builder would not intend many of the things that an English one would, so that these rules are not in force in the colony.

${ }^{279}$ Except in the United States. Cf. Lux v. Haggin (1886) 10 Pac. 674 at 746-51 (Cal.) with Seeley v. Peters (1848) 5 Gilman 130 at $141-43$ (IIl.).

28vo Stott v. Raby [1934] 3 W.W.R. 625 and 630.

201 Mackowecki v. Yachimyc [1917] 1 W.W.R. 1279 at 1296 (Alta. C.A.). Many American decisions on water rights take the same approach, e.g., Katz v. Walkinshaw (1903) 74 Pac. 766 (Cal.). The same physical test was used in Clarke v. Edmonton [1930] S.C.R. 137 at 148-49. See a very interesting discussion of the reasons for this view, in Webb. The Great Plains 432-48 (1931).

28z Bohlen, The Rule in Rylands v. Fletcher (1910.11) 59 U. Pa. L. Rev. 298; Prosser. The Principle of Rylands $U$. Fletcher in Select Topics on the Law of Torts 135 at $187-88$ (1954).

28s (1868) L.R. 3 H.L. 330.

284 Turner v. Big Lake Oil Co. (1936) 128 Tex. 155 at 164, 96 S.W. $2 d 221$ at $225-6$.

2os Allott, supra, n. 242 at 21.

2xs Catterall v. Catterall (1847) 1 Rob. Ecc. 580 at 582, 163 E.R. 1142 at 1143; Re Noah (1962) 36 W.W.R. 577 (N.W.T.); Wolfenden v. Wolfenden [1946] P. 61.

${ }^{207}$ Re Noah, id.; R. v. Nan.e-quis-a.ka (1889) 1 Terr. L.R. 211 (C.A.); cf. Connolly v. Woolrich (1887) 11 L.C. Jur. 197, 3 U.C.L.J. 14, 1 Can. L.J. 253; Penhas v. Tan Soo Eng. [1953] A.C. 304 at 319 (P.C.) (Sing.).

2sw Khoo Hooi Leong v. Khoo Chong Yeok [1930] A.C. 346 at 355 (P.C.) (S.S.), and cases there cited; Bamgbose v. Daniel, supra, n. 242; Coleman v. Shang [1961] A.C. 481 (P.C.).

It is therefore clear, pace Dr. Morris in Dicey and Morris, The Conflict of Laws 287-88 (8th ed. 1967), that these are cases on the local law only and have nothing to do with when English courts recognize polygamous marriages or any other rule of the conflict of laws.

289 Hassan v. Mzee (1943) 11 E.A.L.R. 4 at 6-7 (C.A.).

290 Mayor of Lyons v. East India Co., infra n. 321 at $275-77$ (Moore), 819 (E.R.).

zy Nana Ofori Atta II v. Nana Abu Bonsra [1958] A.C. 95 at 103 (P.C.) (G.C.).

202 Lau Yeong v. Standard Oil Co. (1908) 3 H.K.L.R. 53 at 59-60. 
Now in all the above cases, there were very tangible reasons for not applying the English law. To require monogamy and clergy marriages in many countries would illegitimize three quarters of the population, and punish people for doing what was either impossible, or contrary to their religion, or both. But it is not enough just to say that such and such a country is very different from England in language and religion and race, and thereby exclude any rule of Englisg law which one chooses to exclude. ${ }^{293}$ Thus it was held in India in $1930^{294}$ that:

... in order to show that the English law, on its introduction in 1726, was inapplicable to a particular community, it is not enough to prove that the community had, prior to that date, been governed by a law differing from English law. What must be shown is that the English law is based on or presupposes social or political conditions peculiar to the country of its origin. Here, no attempt has been made to demonstrate that there is any inherent inconvenience in applying the English law of intestate succession to persons of the Jewish community.

We may conveniently close this discussion with a quotation from the argument of the successful counsel in a New Zealand case:295

At the time of the proclamation of the Queen's Sovereignty in New Zealand, human nature was exactly what it was before and since. The propensity to gamble existed, and that was the mischief which induced the statutes against gaming.

\section{(5) Exceptions in Statutes}

But there is one variant of this argument which must be received with great caution. An English statute will often except from its general rules certain named English institutions not found in the colony. Now if there is any evidence that the operation of the rule in the colony would be intolerable unless many institutions in the colony were excepted that would be an argument against applicability. And the fact English institutions are continually mentioned may be one among many pieces of evidence that the statute was bound up with peculiar English problems and so not suitable for export.296 But it is quite another thing to say that because the English Act excepts English institutions not found in the colony, therefore either:

(a) it must be tied to peculiarly English problems, or

(b) its operation in the colony without exception is ipso facto unsuitable.

The decision of the Tasmanian Full Court in Jolly v. Smith ${ }^{297}$ seems to fall into this trap. The Privy Council in A.-G. N.S.W. v. Love ${ }^{298}$ expressly rejected the argument that inapplicability of exceptions leads to inapplicability of the statute.

\section{(6) Parts of the Colony}

A problem which no one seems to have given much thought to is the situation where the English rule or statute is suitable for parts of the colony and not for other parts. The closest one can come to this is the decision in $R$. v. McCormick ${ }^{299}$ that the Nullum Tempus Act was generally in force in Ontario except as to raw, unsurveyed and

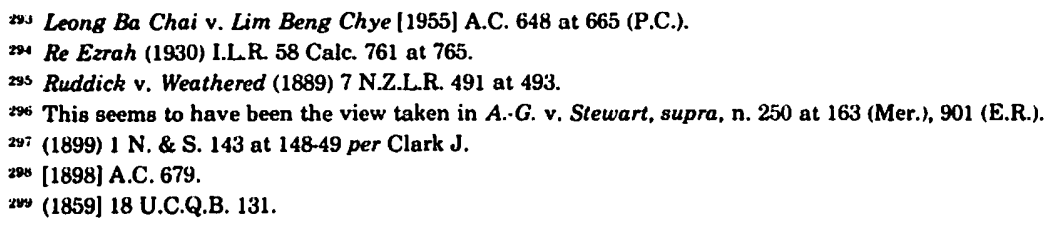


unpatented parts of the province (belonging to the Crown). There is a decision by Chancellor Pound with dicta lending some support. ${ }^{300}$ This seems a sensible view, though one to be used with caution. We may compare it with the relaxation of rules for the solemnization of marriage for those far from clergymen. ${ }^{301}$

\section{(7) Machinery to Implement the English Law}

What is potentially one of the most confusing questions of English law's inapplicability is whether there exists the necessary local machinery to enforce the English law. If it does not one would have doubts as to whether the English law could be applicable. The most usual form this question takes is whether the local courts have jurisdiction to enforce the rules of law in question.

The first thing which we must do is to recognize that a rule of law is one thing, and a court to enforce it is another. Just because one court enforces a rule of law in England does not mean the same court is needed to enforce it in Canada or Borneo. Two different courts can enforce the same law. Then again, one can (in theory at least) conceive of a rule of law which exists without any court with power to enforce it.

The first small fruit of these reflections is that the mere fact that an English statute mentions specific English courts is irrelevant. If a statute mentions the grounds for issue of certiorari from the Court of Queen's Bench, that only gives the grounds for the issue of certiorari: the mention of the court is only procedural. As proof of that, we may recall that there is now no Court of Queen's Bench even in England, it having been replaced by the Supreme Court of Judicature in 1876. If that causes the new English courts no trouble why should it bother an Australian or a Nigerian court? Therefore, statutes referring to the English superior courts (past or present) simply give the general law, and are in no sense merely local or special legislation. ${ }^{302}$ The suggestion by Lord Cranworth in the House of Lords in Whicker v. Hume colonial deeds need be filed in Chancery in England if the statute be in force is ridiculous.

And the same must follow for references in a statute to many other institutions found only in England, such as the Great Seal of England, ${ }^{304}$ or the Attorney-General of England. ${ }^{305}$

The reverse of this problem occurs when there is a general rule of English law which one would like to apply in the colony but there is no local court with jurisdiction to hear such suits.

The first caution is that it is unlikely that this is in fact the case. It was laid down as long ago as 1667 in Peacock v. Bell ${ }^{306}$ that nothing is presumed to be outside the jurisdiction of one of Her Majesty's superior courts. Only an express statutory provision can deprive such a court of

\footnotetext{
:wo Meng v. Coffey (1903) 93 N.W. 713 at 715 (Neb.).

301 Supra, p. 70.

w2 Macdonald v. Levy (1833) Legge 39 at 54-55; Jephson v. Riera (1835) 3 Knapp 130 at 153 (P.C. 12 E.R. 598 at 606; Doe d. Hanington v. McFadden (1836) 2 N.B.R. 260 at 272. 284; Kelly v. Jones (1852) 7 N.B.R. 473; S. v. S. (1877) 1 B.C.R. (pt. 1) 25 at 31, 34; Miller-Morse Hardware Co. v. Smart [1917] 3 W.W.R. 1113 at 1117 (Sask. C.A.).

3u1. (1858) 7 H.L.C. 124 at 161, 11 E.R. 50 at 65.

ws Doe d. Hanington v. McFadden, supra, n. 302 at 283. Note the apparent split in the Manitoba Court of Appeal in Meanwell v. Meanwell [1941] 1 W.W.R. 474.

:us Anderson v. Ah Nam (1904) 4 N.S.W.S.R. 492 at 499 ; Quan Yick v. Hinds. supra, n. 239 at 370. Once again the reasoning in Terrell v. Secretary of State [1953] 2 All E.R. 490 at 493, [1953] 2 Q.B. 482 at 493, falls into error.

3003 (1667) 1 Wms. Saund. 73, 85 E.R. 84.
} 
jurisdiction over any matter. Some years ago there was litigation as to whether the English divorce law was in force in Alberta, and one of the main objections was that the statute establishing the Supreme Court of Alberta listed many matters over which it had jurisdiction but divorce was not one of them. What is more, the relevant English statute (the Divorce and Matrimonial Causes Act, 1857) ${ }^{307}$ gave jurisdiction in such matters to a new court composed of the judges of certain named English courts. But Stuart J.308 applied the line of cases stemming from Peacock v. Bell and the Privy Council expressly approved ${ }^{309}$ his reasoning. He said that the Supreme Court of Alberta was plainly constituted as a superior court of record and hence was presumed to have jurisdiction over everything. As there was no statute expressly taking away jurisdiction over divorce, it must have such jurisdiction. Therefore, the argument as to inapplicability based on want of local machinery melted away and the divorce law was held to be in force. There is other authority to the same effect. ${ }^{310}$

Therefore, want of jurisdiction will rarely be a problem at any event when one deals with superior courts in the colony. But what does one do when the local statute does specifically exclude such jurisdiction? Or what does one do if local procedural statutes forbid the procedures needed to implement the English law (presumably this has much the same effect)? Plainly one cannot enforce the English law so long as the local statutes remain, and it is of no practical importance to decide whether or not the English law is theoretically in force (though hamstrung) or not.

What is important is what happens if the local courts later get the jurisdiction they formerly lacked. Is the English law gone forever, or has it merely been dormant so it may awake when the court with the jurisdiction comes along? Though some authorities suggest that the English rule must be dead forever, ${ }^{311}$ we have really already answered this question in more general fashion above. ${ }^{312}$ We decided there on reason and authority that a colony may initially receive only laws suitable to its rude state, but as its society and commerce develop, more English law becomes applicable. The arrival of additional jurisdiction must be but a particular case of this more general rule. Therefore, the English law (if otherwise suitable) is only dormant while local jurisdiction is lacking. It springs into effectiveness once the jurisdiction is there. ${ }^{313}$

Indeed, there is authority for this specific conclusion, ${ }^{314}$ the most

307 (Imp.) 20 \& 21 Vict., c. 85.

304 Board v. Board [1918] 2 W.W.R. 633 at 648-49 (Alta. C.A.).

${ }^{309}$ [1919] A.C. 956 at 963 (P.C.). The Ontario Court of Appeal by some obscure process evaded the effect of this decision in Vamuakidis v. Kirkoff [1930] 2 D.L.R. 877.

Ito Jephson v. Riera, supra, n. 302, though this case seems to turn more on the precise wording of the local charter of justice, as does Doe d. Hanington v. McFadden, supra, $\mathrm{n}$. 302, and as does one of the four judgments in Kelly v. Jones, supra, n. 302, but the other judgments seem not to be so limited, nor does Whitby v. Liscombe (1875) 23 Grant $\mathrm{Ch}$. 1 at 14 . Such wording forms only one of the grounds for decision in $S$. v. S., supra, $n$. 302. Whether this is true of Quan Yick v. Hinds, supra, n. 239 at 370, is unclear. Bursey v. Bursey (1966) 58 D.L.R. (2d) 451 (Nnd.) seems not so limited. As to a peculiar exception in Fijian legislation cf. Roberts-Wray, Commonwealth and Colonial Law 901 (1966).

311 Whether A.G. v. Stewart, supra, n. 250 at 163 (Mer.), 901 (E.R.) suggests this is unclear.

112 Supra, p. 66. It is therefore significant to note that Quan Yick v. Hinds, supra, n. 239 at 373-74, comes to the opposite conclusion here and bases it on the infant colony theory. Quan Yick $v$. Hinds has been implicitly overruled by Miller v. Major (1906) 4 CL.R. 219 at 222-23, and Mitchell v. Scales (1907) 5 C.L.R. 405, on this point.

313 Gloth v. Gloth (1930) 153 S.E. 879 at 888 (Va.).

31 Fitzgerald v. Luck, (1839) Legge 118; 1 Bishop, Commentaries on the Law of Marriage and Divorce $\$ 69$ (6th ed. 1881); Advocate General of Bengal v. Ranee Surnomoye Dossee (1863) 2 Moo. P.C. (N.S.) 22 at 39, 15 E.R. 811 at 
recent being a passage from a judgment of Rand J. in the Supreme Court of Canada: ${ }^{315}$

That with the increase of population and the general development of its political,
social and economic life, the apparatus of justice would undergo major modifications
must be attributed to the understanding of the legislators; and that with the extension
of the court system after the patterns then in existence in England and the United
States, such a provision originally inoperative because of the absence of an appeal
Court within the Province would then become efficacious through the furnishing of
procedure is, in my opinion, the sound view of what was intended to be done. It was
impossible for the legislators, lacking omniscience, at that time to appreciate the
particulars of such a body of law: their idea was to introduce rules of civil order and
relations which the experience of England had converted into law. The Province was
not at that moment contemplating a constitutional change which would take it out of
its power thereafter to deal with divorce; what was intended was to infuse the life of
the Province with the matured rules of conduct of an older society to which resort,
present or future, could be made: to fill, as it were, the lacunae in its legal order. I see
nothing incompatible with a legal system in the early stages of organization that laws
be so enacted generally even though at the time the machinery for enforcement is not
then in existence. The adopted restraint, for example, would be during the time of
appeal as and when that should be available. If for some reason an appeal, existing in
1858, were temporarily abrogated, would the substantive rule thereupon disappear? I
should say not.

Of course we must not think that the effect of want of machinery is always restricted to rendering English law dormant. In the right case it might be of such a nature as to lead to total inapplicability having regard to all the circumstances. But they would have to be a very special case. Dr. Kennedy ${ }^{316}$ suggests that an isolated provision in a statute tied to certain machinery might be inapplicable though the rest of the statute was in force. And the Privy Council has suggested ${ }^{317}$ the same might be true of provisions for formal proof of overseas legislation and like procedural matters. Such non-applicability could arise where there was either:

(a) only a minor part of the law thereby excluded from application, or

(b) machinery lacking which was important both relative to the English law in question, and also absolutely.

To disregard the rule of dormancy and refuse to apply an entire English statute because of a lack of some of the incidental machinery is to let the tail wag the dog. Whicker v. Hume ${ }^{318}$ and like cases come perilously close to making this mistake.

\section{(8) General Usage}

In any doubtful area of the law, it is useful to know what has been the practice of lawyers and of laymen affected by the law. Their practice is a good guide to what is convenient and what is generally thought just. To lay down a rule of law contrary to what has been the general practice would defeat expectations, produce uncertainty, and work injustice. These considerations are all the more cogent when the question is as to the applicability of some English rule of law or statute. If the rule or statute has been used on numerous occasions without manifestly

817; Doe d. Hanington v. McFadden, supre, n. 302 at 280; Brett v. Young (1882) 1 S.C. (N.Z.) 262 at 264 (C.A.); A.-G. Vict. v. Moses [1907] V.L.R. 130 at 142.43 (C.A.); Miller v. Major, supra, n. 312; Brown v. Brown (1956) 20 W.W.R. 321 (B.C.C.A.), especially at 326-28; Sidney Smith J.A. dissenting in Densmore v. Densmore (1956) 19 W.W.R. 252 at 259 (B.C.C.A.); the majority were reversed, sub. nom. Hellens v. Densmore in [1957] S.C.R. 768, and Rand J. expressly agreed with the idea of dormancy, at 782-83.

sis Hellens v. Densmore, id. at 782-83.

316 Introduction of English Laws (1957) 2 U.B.C. Leg. N. 419 at 422.

317 Ibrahim v. R. [1914] A.C. 599 at 609; 83 L.J.P.C. 185 at 190.

318 Supra, n. 303. 
unsatisfactory results to decalre it unsuitable would be not only unjust but illogical. 'The proof of the pudding is in the eating.'319 Though there is a little authority to the contrary, ${ }^{320}$ there are numerous decisions in support of the proposition given above. ${ }^{321}$

Indeed, it has been suggested ${ }^{322}$ that such usage alone might make applicable an English statute which would not otherwise be in force. Conversely, Nova Scotia courts appear to hold that it is a grave symptom of unsuitability that an English statute has not been used before, especially as the colony grows older. ${ }^{323}$

\section{(9) Legislative Recognition}

Now a statute does not change the law without words of enactment, and a mere passing reference in a statute, or even a plain implication as to what the legislature thinks the law to be, cannot change the law. ${ }^{324}$ Therefore, if an English statute is plainly not applicable, a local or Imperial statute which merely reveals the legislator's belief that the English statute is in force does not make it so, unless the statute enacts that it shall be so. But apparently it is otherwise where it is not clear whether or not the English Act is in force, for the Ontario courts have repeatedly held the Mortmain Act to be in force in Ontario (though the contrary has been held in most other jurisdictions) because of an implication in local legislation that it was in force. ${ }^{325}$ There are similar decisions (on other statutes) in New Brunswick and in Australia. ${ }^{326}$ of course legislative implication is as effective if it tends to show the English statute not to be in force. ${ }^{327}$

\section{(10) Wisdom of the English Law}

Now as we saw above, ${ }^{328}$ the local courts can always conclude that English decisions (on common law or statutory interpretation) are mistaken and refuse to follow them. But it is a very different thing to say that one's views as to the wisdom of a statute or rule of law can affect whether the statute or the rule is applicable to the local circumstances. Many people doubt the wisdom of the Statute of Frauds, but it is universally held to be part of the English law received. And in fact the courts have refused to consider the wisdom of the English rule in this connection. ${ }^{329}$

\section{(11) Precedent}

We saw above ${ }^{330}$ that the fact that an English statute or rule was not

319 Even if Coke never did translate this into Latin and thereby create an ancient legal maxim.

320 The report of the Master in Freeman v. Fairlie (1828) 1 Moo. Ind. App. 305 at 320 (P.C.), 18 E.R. 117 at 125; the advice of the Board did not mention this; Jolly v. Smith (1809) 1 N. \& S. 143 (Tas. C.A.).

${ }_{221}$ Macdonald v. Levy, supra, n. 302 at 58; Doe d. Hanington v. McFadden, supra, n. 302 at 272-73, 280; Mayor of Lyons v. East India Co. (1836) 1 Moo. 175 at 278 (P.C.), 12 E.R. 782 at 820; Kelly v. Jones, supra, n. 302 at 473 74; Glasson v. Egan (1866) 6 N.S.W.S.C.R. 85 at 87; Walker v. Solomon (1890) 11 N.S.W.L.R. 88 at 103 (C.A.); Barrett v. Austin (1898) 8 Qld. LJ. 157 at 158 (C.A.); Lawal v. Younan, supra, n. 250 at 257.

322 Slapp v. Webb (1850) 1 N.S.W.S.C.R. App. 54 at 55.

323 Uniacke v. Dickson, supra, n. 265, foll'd in R. v. Porter (1888) 20 N.S.R. 352 at 356-57. Cf. Anglin J. in Travis. Barker v. Reed [1928] 3 D.L.R. 927 at 929 (S.C.C.). But the proposition in the text is supported by Rand J. in $A$.G. Alta. v. Huggard Assets Ltd., supra, n. 250.

324 Maxwell on Interpretation of Statutes 304-08 (11th ed. 1962).

325 Doe d. Hanington v. McFadden, supra, n. 302 at 281-82.

326 Walker v. Solomon, supra, n. 321 at 105; Mitchell v. Scales, supra, n. 312 at $411 ;$ A.-G. v. Edgley (1888) 9 N.S.W.L.R. 157 at 160-61. Cf. Ex p. Jenkins (1868) L.R. 2 P.C. 258 at $270-71$.

327 Mitchell v. Scales, supra, n. 312 at 411.

323 Supra, p. 55.

329 M'Hugh v. Robertson, (1885) 11 V.L.R. 410 at 430; Delohery v. Permanent Trustee Co., (1904) 1 C.L.R. 283 at 310.11; and see Stuart J. dissenting in Mackowecki v. Yachimyc, supra, n. 281 at 1284-85.

330 Supra, p. 66. 
applicable in earlier times does not preclude its becoming applicable later. But in the absence of proof of such an occurrence, there is no reason why the ordinary rules of stare decisis should not make binding previous decisions as to whether a particular rule or statute is in force in the colony. ${ }^{331}$

\section{APPLICABILITY OF PARTICULAR AREAS OF LAW}

In the preceding chapter, we examined the general approach which the courts take to whether or not some part of English law are not in force because they are unsuited to the conditions of the colony. Each such case must be decided independently on its merits and (with the exceptions noted in the chapter on the parts of English law received) no binding general rules exist by which one can positively predict whether a given rule or statute will be held in force or not. ${ }^{332}$ Nevertheless, we can examine what the approach of the courts has been or should be to certain areas of English law in order to see what laws they are reluctant to hold in force and which ones they presume are in force. This task is complicated by the fact that in ruling on individual parts of English law the courts usually express no general rules whatever. ${ }^{333}$ Therefore, at times we can do little better than to draw conclusions from a catalogue of English decisions on particular rules or statutes.

\section{A. Procedure, Practice, and Pleading}

We noted before ${ }^{34}$ that in some jurisdictions, the English law of procedure may not be in force at all. Some areas, for instance, have statutory provisions which expressly or by implication exclude resources to English practice. ${ }^{335}$ But in jurisdictions where there is no reason in principle why English procedure could not be in force, do the courts regard it as suitable?

Here a preliminary distinction is necessary. The law of evidence is not substantive law, and it and procedure are often lumped together under the heading of "adjectival law". But no one has any real doubts that the English law of evidence is in the main suitable for reception into a colony. It is every day applied all over the Commonwealth, and only occasionally because of an express statutory provision. ${ }^{336}$ Nor does the fact that it is sometimes introduced by statute detract from its applicability; the fact that the legislatures of some colonies have thought it so desirable as to be specially worth introducing ${ }^{337}$ and that it seems to have worked well there only reinforces our conclusion as to its suitability.

Of course we must not confuse with evidence substantive rules of law cloaked as presumptions, or rules of construction. The law of evidence may have something to say as to their effect or rebuttal, but whether they are in force at all is governed by the relevant part of the substantive law. An example is the rule relating to testamentary provisions in partial restraint of marriage. 338

\footnotetext{
s31 See Re Budd Est., supra, n. 249, and cf. Hargrave J. dissenting in R. v. Valentine (1871) 10 N.S.W.S.C.R. 113 at 129.

3.32 On presumptions, cf. Quan Yick v. Hinds (1905) 2 C.L.R. 345 at 363.

333 Lawal v. Younan [1961] All Nigeria R. 245 at 255.

334 Supra, p. 62.

335 E.g., Ontario divorce law before 1968: Morris v. Morris [1951] I D.L.R. 38 at $46-47$ (H.C.).

336 Ibrahim v. $R$. [1914] A.C. 599 at 609; 83 L.J.P.C. 185 at 190.

337 As in South Africa: see Hoffman, The South African Law of Evidence (1963).

33a Leong Ba Chai v. Lim Beng Chye [1955] A.C. 648 at 655 (P.C.).
} 
Turning to procedure properly so called, there is some Nineteenth Century authority holding that it is in force, without any difficulty whatever appearing. ${ }^{339}$ Indeed, it is even suggested in one case that a grant to the local court of the powers of the English King's Bench gave the local court the King's Bench's procedure, ${ }^{340}$ though that seems to confuse jurisdiction with procedure. Aside from those authorities, however, one finds little else, and it is probable that codification of procedure in most jurisdictions has made the question academic, except where interpretation of the code is in doubt.

\section{B. Taxation or Revenue Law}

Very few cases deal with this subject, probably because of a general assumption that such law is clearly unsuitable. A few decisions have spelled this out, ${ }^{341}$ and Blackstone agrees. ${ }^{342}$ After all, this is but one of a large number of areas of statute law which are more administrative in character than real "lawyer's law". The setting of a budget, and hence of the rates and modes of taxation, is something which each colony must do for itself. Any colonies too new or too small to do so would plainly be the worst possible places to introduce all the details of English tax law. And the tariff structure of an advanced industrial country like England would most probably be the worst possible tariff structure for a colony with few manufactures of its own.

\section{Regulatory and Penal Law}

We noted above that the authorities give us little guidance as to what penal law is or is not in force. One of the few clues that we have is Blackstone's oft-quoted statement ${ }^{343}$ that among the frills of English law are:

The artificial refinements and distinctions incident to the property of a great and commercial people, the laws of police and revenue, (such especially as are enforced by penalties). ...

What did he mean by "the laws of police"? It seems quite likely that he took the phrase from $R$. v. Vaughan in $1769,{ }^{344}$ a decision that 5 \& 6 Ed. 6 c. 16 and other statutes were "positive regulations of police, not adapted to the circumstances of a new colony." That was a prosecution for an attempt to purchase an office in Jamaica. Can this simply refer to criminal law? Surely not, for the raw colony needs criminal law far more than civil law. In Canada's Northwest Territories today there are far more prosecutions than civil suits.

Police forces as we know them did not exist in 18th Century England, but it seems probable nevertheless that "laws of police" refers to policing or regulation of the community. This is a branch of criminal law which can be distinguished both from elementary criminal wrongs like assault or theft, and from protection of the state from treason, sedition, corruption, and peculation. Thus the Shorter Oxford English Dic-

3.39 Kelly v. Jones (1852) 7 N.B.R. 473 at 474; S. v. S. (1877) 1 B.C.R. (pt. 1) 25 at 31; cf. Brett v. Young (1882) 1 S.C. (N.Z.) 262 at 264 (C.A.).

340 Kelly v. Jones, id.

34 Yonge v. Blaikie (1882) 1 Nfld. R. 276; Uniacke v. Dickson (1848) 2 N.S.R. 287 at 291; Winterbottom v. Vandon \& Sons Ltd. [1921] S.A.S.R. 364 at 369 .

3421 Bl.Comm. 107.

343 Id.

344 Burr. 2494 at 2500,98 E.R. 308 at 311 (K.B.). The phrase in question is not in the first edition (1759) but is in the second (1766) and subsequent editions. I am indebted to Professor Philip Slayton of the Faculty of Law, McGill University, for this information. 
tionary ${ }^{345}$ gives (among others) the following two definitions of police:

2. The regulation, discipline, and control of a community; civil administration; enforcement of law; public order 1716. . . .

3. The department of government which is concerned with the maintenance of public order and safety and the enforcement of the law 1730. ... The p[olice] of Glasgow consists of three bodies; the magistrates with the town council, the merchants house, and the trades house 1774.

One would therefore take "laws of police" to refer to provisions for local government and administration, such as curfews, licensing and regulation of taverns, harbor regulations, laws for safety in travel and factories, the manner of conducting local government, and the like.

The next case to be found on point is an ambiguous decision ${ }^{346}$ from Newfoundland in 1822, where Forbes C.J. held liquor licensing laws were in force, quoting with reservations the passage from Blackstone mentioned above, and continuing:

A police of some sort is necessary to the well-being of every community in the earliest stages of its existence; the appointment of a Justice of the Peace and of a constable is in pursuance of the laws of police just as much as the power of suppressing disorderly houses; and a power of this sort may be just as essentially connected with the interest of a rising society as the power of suppressing a riot or of apprehending a felon.

This has force, yet is not completely satisfactory. In the first place, we may suspect that the judge was using the new meaning of the word "police" as referring to a constabulary, a meaning not current in Blackstone's time. But even leaving aside these semantic considerations and precisely what Blackstone had in mind, the proposition is still defective. Public order must be kept and so regulatory laws are necessary. But it does not follow from this that the laws in England are suitable. In most parts of Canada liquor control was thought necessary in early times, especially because the local Indians had been exploited by means of liquor. But the English laws for the licensing of public houses would have been totally unsuitable and even unworkable. It may well be that the passage last quoted was colored strongly by the lack of a local legislature in Newfoundland ${ }^{347}$ in 1822.

The suggestion above that "laws of police" are the regulatory parts of criminal and quasi-criminal law, and are probably not in force, is borne out by an Australian decision a few years later. ${ }^{348}$ There the usury laws were held not to be applicable, Forbes C.J. ${ }^{349}$ this time saying that they were regulations of police for particular times and places. Then again, the Gaming Acts were held in force in New Zealand, Prendergast C.J. saying 350 that Blackstone must have meant local or municipal regulations, for New Zealand had relied on English criminal law for some years. ${ }^{351}$ Indeed, even the decision in $R$. v. Vaughan might go too far he said. Therefore, he had no doubt that a statute could be in force even if it was penal. And the High Court of Australia has also taken Blackstone's

34s Vol. 2 at 1536 (1964 revision).

346 Yonge v. Blaikie, supra, n. 341 at 282.

347 An assembly only came in December 1832.

3s Macdonald v. Levy (1833) Legge 39, especially at 56.

349 This was the same man quoted above, who was Chief Justice of Newfoundland ten years before: Higgins, How the Rule of Law Came to Newfoundland (1955) 5 Chitty's L.J. 192 at 200.

350 Ruddick v. Weathered (1889) 7 S.C. (N.Z.) 491 at $493-494$.

35 I But Sifton C.J., dissenting in Fraser v. Kirkpatrick (1907) 6 Terr. L.R. 463, pointed out that as liberty of the subject was at stake, in criminal matters doubts as to what was the law should be resolved in favor of the accused, i.e., against the reception of doubtful penal laws. 
words to refer only to regulation of social conditions, applying the term to vagrancy laws. ${ }^{352}$

\section{Statutes}

We noted above ${ }^{353}$ that, in general, statutes should be treated the same way as common-law rules, but that some courts tend to lean against their reception presumably because they are difficult to know of or consult, though Uniacke v. Dickson ${ }^{354}$ also suggests that statutes may reflect the needs of a fleeting moment as common-law rules never do.

There has been some discussion as to the applicability of parts of a statute, but it may be unwise to be too dogmatic here for statutes vary a good deal. Some statutes are only a motley herd of unrelated provisions straggling along after a common chapter number, while others disclose a carefully drafted scheme relating to a single topic, and all of whose provisions are necessary if the scheme is to work successfully. Between these extremes we meet all possible intermediate situations.

Therefore, so long as one is not breaking up an integrated piece of legislative machinery, there should be no objection in principle to picking and choosing among applicable parts of a statute, and this is sometimes done. ${ }^{355}$ And 80 it is ridiculous in the ordinary case to suggest that a statute otherwise applicable ceases to be so because it contains a few inapplicable provisions: these are just inoperative and so omitted when the statute is received. ${ }^{356}$

On the other hand, courts are reluctant to apply isolated provisions of a statute, the bulk of which is inapplicable. ${ }^{357}$ Of course there can be special circumstances which create an exception to this: the law on liability for fires spreading is, for instance, contained in one general section in an Act which otherwise applied only to London. ${ }^{358}$ Yet this one section has often been held in force in various places all over the Commonwealth. There is a dictum ${ }^{359}$ that because of this it is possible that there could be an isolated provision in a statute in force in colonies. But in general the courts' reluctance to hold any such isolated provisions applicable seems wise, for individual provisions in a statute are often only just or workable if the whole scheme of the Act is applied. Seemingly general provisions may have been inserted in the statute only as exceptions from, or compensations for, its general provisions.

It is not surprising that the courts will not take a single provision in an English statute and apply it out of its context. Thus an English statute provided for licenses to marry in places other than churches or public chapels, and provided that such licenses should be effective only if obtained before the ceremony: if the license was obtained later the marriage would be void. A British Columbia court refused to apply this

352 Quan Yick v. Hinds, supra, n. 332.

$3 s 3$ Supra, p. 60.

sst (1848) 2 N.S.R. 287.

35 Until 1968 when a new Act came into force, this was done to the Divorce and Matrimonial Causes Act, 1857, by courts in Western Canada.

$3 s 6$. v Colan (1878) 1 N.S.W.S.C.R. (N.S.) 1; A.G. N.S.W. v. Love [1898] A.C. 679 at 686 (P.C.); Quan Yick v. Hinds, supra, n. 332 at 364; Anderson v. Ah Nam (1904) 4 N.S.W. S.R. 492 at $495-96$ (C.A.).

357 Shea v. Choat (1836) 2 U.C.Q.B. 211 at 221; Uniacke v. Dickson, supra, n. 341 at 300 ; R. v. Porter (1888) 20 N.S.R. 352 at 356; Jolly v. Smith (1899) 1 N. \& S. 143 at 157 (Tas. C.A.); Quan Yick v. Hinds, supra, n. 332 at 364; Mitchell v. Scales (1907) 5 C.L.R. 405 at 410-11; Shaik Saheed v. Sockalingam [1933] A.C. 342 at 344-45; 102 L.J.P.C. 111 at 113 (P.C.) (Str. Setts.).

3ss (Imp.) 14 Geo 3, c. 78, 8. 86.

uss Winterbottom v. Vardon \& Sons Ltd., supra, n. 341 at 370

300 Penner v. Penner [1947] 4 D.L.R. 879 (B.C.S.C.). 
provision as to tardy licenses generally to the general scheme of marriage licenses, holding that the statutory provision was confined to the particular licenses provided for in the English Act. ${ }^{360}$

\section{E. Religious Disabilities}

We have discussed above $e^{361}$ whether ecclesiastical law is in principle received as part of English law. We may now turn to a group of statutes which undoubtedly formed part of the general English law enforced by ordinary courts, and not the ecclesiastical law enforced by the ecclesiastical courts. These are the statutes establishing criminal penalties and civil disabilities for persons not members of the Church of England. They would be in force in the colonies unless they are from their nature unsuited to the conditions in the colonies.

The first group of these statutes ${ }^{362}$ was not substantially repealed in England until $1778^{363}$ and $1791^{364}$ and so all of this group, unless inapplicable, would be in force in Canada's Maritime Provinces, Bermuda, and in many of the islands in the Caribbean. These earlier statutes imposed criminal penalties for failure to attend Anglican services, for the exercise of many callings or the holding of offices by non-Anglicans, ${ }^{365}$ and for failure to take oaths which many nonAnglicans, and certainly Roman Catholics, could not take. ${ }^{366}$ Various penalties were provided for the exercise of non-Anglican ceremonies ${ }^{367}$ or membership in various Catholic orders. ${ }^{368}$ The penalties for non-Anglican service were much diminished in 1688 for those Protestant dissenters who would swear or affirm allegiance, while soon after Quakers were allowed to affirm in civil proceedings. ${ }^{369}$ But the penalties for Catholics were at the same time increased. ${ }^{370}$

Even after the reforms of 1688,1778 and 1791 mentioned above, there remained a number of religious disabilities for non-Anglicans. No dissenter (or Catholic) could hold any sort of public office and there were residual restrictions on their worship. Indeed conditions grew worse in some respects. The Marriage Act, $1753^{371}$ invalidated their marriage ceremonies. In addition to some very strong remaining theoretical restrictions on the exercise of the Catholic religion (which were not enforced), and a few added in the early 18th Century, 372 new penalties and offences were enacted by the Roman Catholic Relief Act, $1829^{373}$ which for the most part removed the existing disabilities of Catholics. Some of the old disabilities were removed by various Statute Law Reform Acts during the 19th Century but the remainder of the disabilities lasted until 1926. ${ }^{374}$ Though very few of these statutes had any practical effect in England in

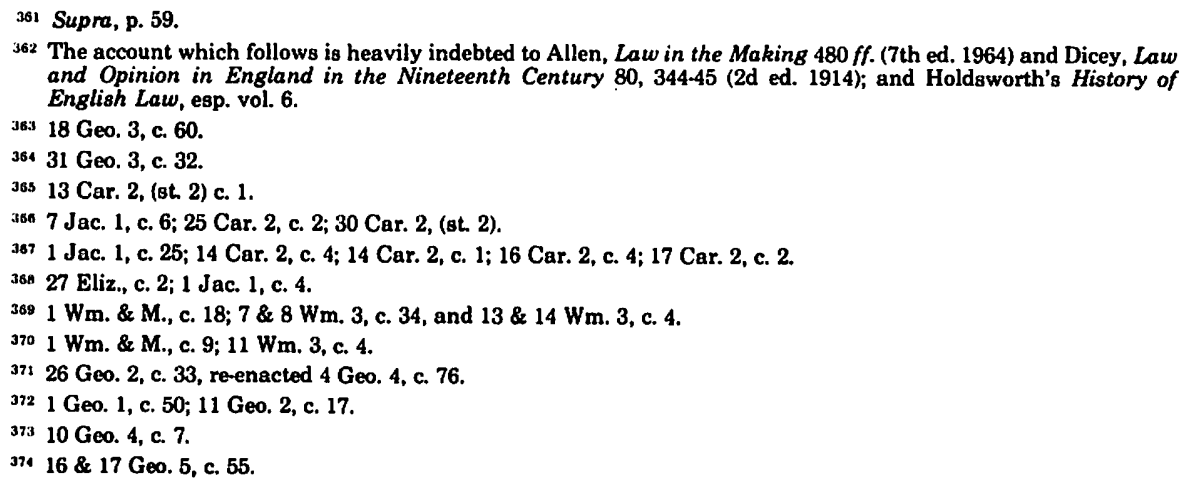

36: The account which follows is heavily indebted to Allen, Law in the Making $480 \mathrm{ff}$. (7th ed. 1964) and Dicey, Law and Opinion in England in the Nineteenth Century 80, 344-45 (2d ed. 1914); and Holdsworth's History of English Law, esp. vol. 6.

J6: $18 \mathrm{Geo} .3, \mathrm{c.} 60$.

$36431 \mathrm{Geo} .3, \mathrm{c} .32$.

36s 13 Car. 2, (st. 2) c. 1.

3sa 7 Jac. 1, c. 6; 25 Car. 2, c. 2; 30 Car. 2, (st. 2).

3871 Jac. 1, c. 25; 14 Car. 2, c. 4; 14 Car. 2, c. 1; 16 Car. 2, c. 4; 17 Car. 2 , c. 2.

36A 27 Eliz., c. 2; 1 Jac. 1, c. 4.

${ }^{369} 1 \mathrm{Wm}$. \& M., c. $18 ; 7 \& 8 \mathrm{Wm} .3$, c. 34 , and 13 \& $14 \mathrm{Wm} .3$, c. 4.

3701 Wm. \& M., c. 9; 11 Wm. 3, c. 4.

37326 Geo. 2, c. 33 , re-enacted 4 Geo. 4 , c. 76.

3721 Geo. 1 , c. 50; 11 Geo. 2, c. 17.

37310 Geo. 4, c. 7 .

$37416 \& 17$ Geo. 5, c. 55. 
the 19th Century, still they were of full force and effect in the eyes of the law at the time as of which most colonies received English law.

One cannot for a moment imagine that any of these statutes would be held applicable in any such colony however. ${ }^{375}$ Not only do they predicate an official established church, but they also assume that religion has a political significance. The Civil War made Protestant dissenters appear to be dangerous revolutionaries, while the wars with Spain, and later Irish and Scottish politics, and the 1688 succession, made Catholics appear to be adherents of rival contenders for the throne. The popular feeling on such matters, even at a comparatively late date, can be seen from the Gordon Riots of 1780's. None of this is true of any colony, and it is indeed probable that Anglicans form a minority in most of these territories. Legal disabilities based on religion have been repugnant to popular feeling since at least the latter part of the 19th Century, when most colonies were planted. It therefore seems clear that none of these Acts could be held in force outside England, quite apart from any repeals or inconsistent legislation in force in individual territories.

\section{REPEAL OR AMENDMENT OF THE IMPORTED ENGLISH LAW}

At the beginning of this article we noted ${ }^{376}$ that English law only serves as the background of a colony's law where local statutes (and Imperial statutes in force proprio vigore) are silent. Of course it also forms a background against which these statutes may be interpreted. Because its effect is subject to the local statutes, and because the English law received is part of the local law, the local legislature can repeal or amend part or all of the English law received, ${ }^{377}$ whether it consists of English statutes or common-law rules.

We must repeat that this repeal or amendment has no constitutional significance, for since the Colonial Laws Validity Act, no local law can be questioned on the ground that it conflicts with English law. ${ }^{378}$ Except as provided in the Statute of Westminster or similar legislation, local legislation cannot conflict with Imperial statutes, 379 but this means Imperial statutes in force by their terms as such and passed by the Imperial Parliament to be part of the law of the colony. Acts of the Parliament at Westminster received as part of the law of England, and not intended by that Parliament to be in force in the colony, are fully under the control of the local colonial legislature. ${ }^{380}$

This distinction may be made more clear by a reference to conquered colonies which have French or Roman-Dutch law. Several of the French codes are in force in Mauritius, but there is no doubt that the local legislature could repeal or amend them. Indeed, (Southerm) Rhodesia, which has Roman-Dutch law, has in recent years repealed a centuries-old Roman Senatusconsultum!

And to confirm this reasoning we may look at a decision of the Privy

at Cf. Scott v. Scott (1970) 15 D.L.R. (3d) 374 (N.B.C.A.).

3i6 Supra, p. 30.

si: Of course in a federal state each legislature can repeal or amend only the parts of English law forming part of the law over which it has legislative competence.

376 Supra, p. 34.

3i9 Subject to the powers given in the Statute of Westminster to the Dominions and in like statutes to territories which have gained such status or independence since. But the Australian states have never been so excepted from the Colonial Laws Validity Act.

:*1 1 Keith, Responsible Government in the Dominions 339 ff. (2d ed. 1928); MacRae, Constitutional Law 66-67 [mimeographed; n.d.; Toronto ca. 1940?]; K. v. M'Carthy (1873) 4 Aust. Jur. R. 155 at 156 (Vict.); Chia Gee v. Martin (1906) 3 C.L.R. 649 at 653. 
Council, Harris v. Davies. ${ }^{381}$ There the New South Wales legislature had passed an Act allowing costs in a slander suit even if the plaintiff recovered only nominal damages. This was in effect a repeal of $21 \mathrm{Jac}$. 1 , c. 16, s. 6, which would otherwise have been in force in the colony, and it was contended that such a repeal was beyond the powers of the local assembly. But the Privy Council expressly affirmed its power "to repeal the statute of James ... if it thought fitting. ..."

Therefore, it follows that the colony's ordinary methods of repeal of amendment may be used without need for special forms or procedures. Because of this express words are unnecessary and an implied repeal will do, as for instance where the local legislature has passed legislation inconsistent with the English statute (or common-law rule) in question. ${ }^{382}$ It is purely a question of statutory construction whether this is the case or not. It has been .held sufficient to work an implied repeal that new local law removes the rationale for the English rule of law, ${ }^{383}$ or substitutes a new procedure for that contemplated by English law. ${ }^{384}$ And of course there may well be a repeal where a local statute copies the English provision and then is itself repealed. ${ }^{385}$

The real problem, however, comes where the local legislation is not inconsistent with the English law (or at any rate not to any great degree), but covers much the same area. Where it is common law involved, the question is familiar and arises in England too: did the legislature intend the new Act to be a complete code, shutting out the common law entirely? Where there is a question of English statutes, the problem is really very similar, though one cannot assume that the courts will treat the two situations absolutely identically. After all the common law has a familiarity and a naturalness and connection with other areas of the law which English statutes rarely have. And the common law supplies a whole conceptual framework from which even modern statutes rarely depart.

Of course if there is a plain intention displayed to codify the law on one subject that will go a long way toward showing that there is an implied repeal of the previous law, even where it is not strictly inconsistent. ${ }^{386}$ But with few exceptions, it is very difficult to see whether this was what was intended and common-law judges are usually reluctant to find that this was in fact the case. ${ }^{387}$

Where a local statute copies much of an English statute which was in force one would assume that it impliedly repealed the English statute and thereby abolished the parts not copied. ${ }^{388}$ And $a$ fortiori if all of an English legislative provision is copied by local legislation. ${ }^{389}$ But of course it is otherwise if there are express words showing the English statute still

381 (1885) 10 App. Cas. 279 at 281.

$3{ }^{3 * 2}$ Harris v. Davies, id.; $R$. v. Valentine (1871) 10 N.S.W.S.C.R. 113 at 129 ; cf. Hauer v. Hauer (1956) 20 W.W.R. 89 at 90 (Sask.); Doe d. Hanington v. McFadden (1836) 2 N.B.R. 260 at 273.

${ }^{3 * 3}$ Quinn v. Beales [1924] 3 W.W.R. 337 (Alta. C.A.).

$3 s 4$ Canadian Bank of Commerce v. Carbonneau (1905) I W.L.R. 263 (Y.T.).

3ss Nolan v. McAdam (1906) 39 N.S.R. 380 (C.A.). But not where the provision re-enacted locally and then repealed was only a legislative interpretation of an earlier Act: Lamb v. Cleveland (1891) 19 S.C.R. 78, especially at 103, cf. 84 .

${ }_{366}$ Quan Yick v. Hinds (1905) 2 C.L.R. 345 at 363; Mitchell v. Scales (1907) 5 C.L.R. 405 at 412; Sorley v. Surawski [1953] Qld. S.R. 110 at 112-15; Royal Bank v. Pischke [1933] 1 W.W.R. 145 at $153-54$ (Sask. D.C.).

38; Re Application of Alliance Assurance Co. (1960) 33 W.W.R. 180 at 182 (B.C.S.C.).

384 Mitchell v. Scales, supra, n. 386, at 414; Inspector General v. Kamara (1934) 2 W.A.C.A. 185 at 187; Sorley v. Surawski, supra, n. 386. But cf. Barrett v. Austin (1898) 8 QId. L.J. 157 at 158 (C.A.), and Lamb v. Cleveland. supra, n. 385 .

3sy Hazelwood v. Webber (1934) 52 C.L.R. 268 at 275-76. 
to be in force, ${ }^{390}$ or the English statute had been passed to remedy a small defect in the law which was in turn copied by the local Act. ${ }^{391}$

Where there are none of these plain indications to rely upon, and simply a large overlap between the English law and the colonial law, one cannot predict the result with certainty. But usually the colonial courts will hold the English statutes thereby repealed, ${ }^{392}$ but not the common law. 393

What if the local statute repealing the English law is itself repealed? Does the English law revive, in the absence of some specific provision to the contrary in the local statutes? Probably there is no revival. ${ }^{394}$ But where there was only an implied local repeal of the English law it has been held that repeal of the local law does revive the English law. ${ }^{395} \mathrm{~A}$ very complicated problem arose in Manitoba, where there was local legislation inconsistent with the English Debtors' Act, before English law was introduced. A local statute was passed introducing English law as of a date which would include the English Debtors' Act. Then the local legislation inconsistent with the English Debtors' Act was repealed. It was held ${ }^{396}$ that this did not revive the Debtors' Act, first because it has never been part of Manitoba law, and second because the English law introduced included (Imp.) 13 \& 14 Vict., c. 21, s. 5, which enacted that repeal of a repeal should not revive the original law.

Of course this latter rule does not apply to repeal of a mere modification in the old law, which then restores the old law to its original state.397 And a fortiori where a local statute replacing the English statute is repealed the English statute is revived (if, indeed, it ever ceased to be in force)..$^{398}$

\section{REFORM OF THE ENGLISH LAW RECEIVED}

Lawyers in a country which has received English law experience comparatively little difficulty in finding the rules of the common law applicable to a particular situation. But finding the relevant English statutes is much more difficult. In the first place, England has never had an official legislative revision of her statutes in all the seven hundred and more years Parliament has been passing statutes, and so English statutes have always been comparatively difficult to find and know. Secondly, a lawyer in a colony which has received English law does not want the current English statutes, or even such of the current English statutes as

3ov Doe d. Hanington v. McFadden, supra, n. 382 at 274.

ssi R. v. Ah Pow (1880) 1 B.C.R. (pt. 1) 143 at $148-49$.

392 Uniacke v. Dickson (1948) 2 N.S.R. 287 at 292; Wallace v. King (1887) 20 N.S.R. 283 at 289 (C.A.): R. v. Porter (1888) 20 N.S.R. 352 at $357-58$; Jolly v. Smith (1899) I N. \& S. 143 at 152 (Tas. C.A.); R. v. Hilaire (1903) 3 N.S.WS.R. 228 (C.C.R.); cf. A.-G. Vict. v. Moses [1907] V.L.R. 130 at 144 (C.A.); Mitchell v. Scales, supm, n. 386; Raisbeck v. Desabrais (1970) 16 D.L.R. (3d) 477 (Alta. C.A.). Even where one statute is basically civil and the other criminal: Connors v. Egli [1924] 1 W.W.R. 1050 at 1052 (Alta. C.A.).

Contra, Aarons v. Rees (1898) 15 N.S.W.W.N. 88 at 90, 91 (C.A.); R. v. DeBaun (1901) 3 W.A.L.R. 1 at 10 (C.A.). And cf. n. 398 infra.

39.3 See Russell on Bills 2 ff. (3d ed.).

394 Cf. R. v. DeBaun, supra, n. 392. In support of the proposition in the text is Reid v. Fitzgerald (1926) 48 N.S.W.W.N. 25 at 26, which was approved on this point in Hazelwood v. Webber, supra, n. 389 at 276.

395 Aarons v. Rees, supra, n. 392 at 90; Lamb v. Cleveland (1891) 19 S.C.R. 78 at 84.

350 Re Bremner (1889) 6 Man. R. 73 at 75-76 (C.A.).

397 Foley v. Webster (1893) 3 B.C.R. 30 at 31 citing Levi v. Anderson (1869) L.R. 4 Q.B. 330 and Mount v. Taylor (1868) L.R. 3 C.P. 645.

Lamb v. Cleveland, supra, n. 385 at 84 , has a statement to the effect that there is always a revival of the English law on the repeal of a local statute which had re-enacted or affirmed the English law. But that seems to be contrary to most of the authorities cited above.

s98 Sharkey v. Robertson (1969) 67 W.W.R. 712 at 718 (B.C.); cf. n. 392, supra. 
were passed before a given date. He wants the English statutes which were in force on a given date long ago, and there is probably no list of such statutes to be found anywhere, let alone a subject index. ${ }^{399}$ In the third place, even when he has found a relevant English statute which was in force on the appropriate date, he cannot be sure that his local courts may not declare the statute to be inapplicable to the circumstances of the colony, and so not be in force.

Such a state of affairs is disgraceful, for it is of the highest importance that the law be ascertainable. What can be done to remedy the situation? One might be tempted to press for the passage of local legislation repealing all English statutes not yet declared by the local courts to be in force on the theory that any such statute could not be very important or urgently needed.400 The trouble with that theory is that we assume that many rules of law which are used every day are common-law rules when they are not. The law relating to set-off is a prime example, ${ }^{401}$ and there are many others. ${ }^{402}$

Therefore, any reform must begin with some consideration of what English statutes may be in force in the colony, because they were in force in England on the relevant date. Where the colony received English law as of 1869 or later, there is no problem, for in 1870 and every year since the Stationery Office in London has published both a chronological table and an alphabetical subject index to the English statutes in force in that year. Adapting one of these tables to a date a few months earlier or later should be very easy. For a date much before 1869, the task is comparatively tedious, but as these chronological tables also indicate the titles of repealed English statutes and when they were repealed, one can compile such a list for any given date.

The next difficulty is to prune out of the list statutes not in force in the colony because they are unsuitable. Many will plainly be of this sort because they are local, personal, or temporary measures, or concerned with taxation and the like. Unfortunately the bulk of the statutes will be ones about whose applicability there will be varying degrees of doubt, with few decisions by the local courts on point. Here there are two basic choices which the reformer may make. One is simply to compile and publish a complete list with an index and let the local courts decide on each case as it arises. ${ }^{402 a}$

The other alternative is to remove the existing uncertainty by legislative action, by passage of a local Act declaring which of the English statutes are in force and which not. The only modern example of this latter counsel of perfection are the Bahamas, ${ }^{403}$ Western Nigeria's 1959 reform $^{404}$ and Gibraltar's 1962 statute. $^{405}$ There are a surprising number of jurisdictions which have undertaken some such measure of reform, but few have gone so far as Western Nigeria. Intermediate or partial schemes have been more common. One frequently adopted has been an official list of what English statutes are believed to be applicable

\footnotetext{
39: But see, infra, p. 84-5.

${ }^{400}$ Cf. n. 423, infra.

401 See (Imp.) 2 Geo. 2 , c. 22

\$02 E.g., account by co-tenants ( 4 \& 5 Anne, c. 3, s. 27), and some rules of life insurance (14 Geo. 3, c. 48) and fire insurance (14 Geo. 3, c. 78, 8. 83).

so3. The Institute of Law Research and Reform in Alberta has well underway a project along these lines.

403 See Roberts-Wray, Commonwealth and Colonial Law 814 (1966), and Revised Laws, c. 2.

404 Western Nigeria's Law of England (Application) Act, 1959, c. 60, 8s. 3, 4; High Court Law, c. 44, s. 12.

s0s Application of English Law Ordinance 1962 no. 17 (Gibraltar).
} 
and in force. Such lists usually have no legislative sanction whatever, but the distinguished auspices under which they are prepared and the fact they are usually published as an appendix to the local volumes of statutes, have doubtless combined to give them considerable persuasive authority. There have been such lists published in British Honduras, ${ }^{406}$ British Somaliland ${ }^{407}$ (as it then was), the Gambia, ${ }^{408}$ Papua, $^{409}$ New Guinea,410 Sierra Leone,411 Rhode Island, ${ }^{412}$ North Carolina, ${ }^{413}$ New York, ${ }^{414}$ Pennsylvania, ${ }^{415}$ Maryland,, ${ }^{416}$ Georgia, ${ }^{417}$ Kentucky, ${ }^{418}$ Florida ${ }^{419}$ and South Carolina. ${ }^{420}$

Another method which has at least as much to recommend it is a partial legislative intervention. Most jurisdictions have introduced a few specific English statutes by local legislation at one time or another, ${ }^{421}$ and a few have gone further and introduced at one time a whole list of named English statutes. ${ }^{422}$ But this of course does nothing to reduce the clutter of English statutes to be looked up and referred to, and so at least one jurisdiction, Ohio, ${ }^{423}$ cut the Gordian knot by repealing all English statutes in force locally.

That simplifies the law but is probably too drastic. A better method uses a more discriminatory approach. A list of statutes which are probably of no utility is repealed (or declared never to have been in force) by the local legislature. Another group of statutes or parts of statutes which are probably useful is declared by the local legislature to be in force, or even re-enacted. Ideally, the re-enactments would be placed in their appropriate places throughout the local revised statutes, according to subject matter. Finally, there would have to be a third list of English statutes whose applicability was uncertain and would have to be ruled upon by future lawsuits or local legislation. If these three lists were carefully drawn up it would then be quite safe to have the local legislature repeal or declare inapplicable all other English statutes. Of course if the work was properly done there would either be no other English statutes or these statutes would be manifestly inapplicable anyway. Thus this last residual repeal would be designed not to change the law, but rather to simplify research by making it no longer necessary to hunt for unsuspected English statutes. All possibly applicable English statutes would be listed, possibly set out at length, and certainly indexed, in the

\footnotetext{
406 See the schedule to the laws of 1887 , not repeated in later revisions. It had no legislative sanction.

${ }^{407}$ See the list in the 1950 laws, vol. 1, pp. xxiv to xxxii.

40 See the list in the 1955 laws.

4wi Papua: see the 1945 laws.

4:0 New Guinea: see the 1945 laws.

41 See the Laws of Sierra Leone, vol. 4, at 1603-06; see also 1932 nos. 44 and 45, now 1960 Revised Laws vol. 1 at 139 , 194.

112 In 1749: Brown, British Statutes in American Law, 1776-1836 (1964) 31; and see n. 422 infra.

413 An attempt in 1749 which was disallowed, and then lists in 1804 and 1817 : Brown, id. 31, 32, 43, 138-42, 360-77; but see $n .425$ infra.

11 An attempt in 1767, also disallowed: Brown, id. 31.

415 In 1807 and 1817: Brown, id. 32, 89.94.

418 In 1811: Brown, id. 32, 98-102.

417 In 1826: Brown, id. 33, 43, $153-56$.

418 In 1810 (an official list): Brown, id. 33, 133-36; but see n. 421 infra.

119 In 1941, updating a list of 1845: Brown, id. 33, 43, 199-200.

420 Unofficial lists in 1809, 1814, and 1836: Brown, id. 31, 149-52.

421 See for instance Brown id. 31n., 77-81, 130-32, 148-49.

42: E.g., Rhode Island and South Carolina, and in effect, New York, Alabama, Wisconsin, and Iowa: Brown, id.39, 54$56,73,147-48$.

423 Brown, id. 37; but it may well be that (as in the states named in $n .422$ ) this was ineffective because the courts held some statutes to be still in force "as part of the common law" anyway.
} 
local statutes. The only jurisdiction to accomplish so full a reform has been Victoria, by its Imperial Laws Application Act, ${ }^{424} \mathbf{s o}$ ably drafted by Sir Leo Cussen. But these jurisdictions were brave enough to enact measures going even further many years ago: North Carolina,425 Virginia, ${ }^{426}$ New York, ${ }^{427}$ New Jersey, ${ }^{428}$ Vermont, ${ }^{429}$ Mississippi, ${ }^{430}$ Tennessee, ${ }^{431}$ South Carolina, ${ }^{432}$ and Michigan. .33

And at one time or another, a number of jurisdictions have done a good deal in piecemeal fashion. While not finally repealing unknown or unnamed English Acts, they have repealed by name a very large number of English Acts, and re-enacted as part of the local statutes any parts of these English Acts which seemed worth keeping. The result is that while no one could guarantee there were no English statutes lying in wait for the unwary, the possibility would be much reduced. The Bahamas $^{434}$ and New Zealand have done a good deal of this over the years, and Ontario made considerable strides in this direction in $1902 .{ }^{435}$

\section{APPENDIX}

This would be the fitting place in which to set out in summary form the manner in which the English law has been received in various parts of the world, and the date as of which such English law is in force. There are such excellent accounts of the matter now available, however, that for the most part this seems no longer to be necessary.

An old work, very comprehensive in scope but now long out of date, is the multivolume work entitled Commercial Laws of the World (early 1900 's). The discussion of each territory of the British Empire is prefaced with a thorough and accurate summary of its reception of English law. There is a similar coverage in Safford and Wheeler's Privy Council Practice (1901). The modern replacement for these older accounts is the section at the end of Mr. Roberts-Wray's very good book, Commonwealth and Colonial Law (1966). More detail on North American and African territories

124 The text as amended to 1929 is found in the Victorian statutes, 1929, vol. 2, 1149 ff.

12s In 1837: Brown, supra, 34, 37, 146.

42s In 1792 Brown, supra, 34-36, 43, 116-25.

27 In 1767 and 1788: Brown, supra, 37, 43, 69-72, 357-59.

123 In 1799: Brown, supra, 37, 43, 82.

429 In 1797: Brown, supra, 37, 43.

430 In 1807: Brown, supra, 37, 43, 183-84.

4il In 1858: Brown, supra, 37, 43, 179-80.

43. In 1872: Brown, supra, 37, 43.

433 In 1810 and 1820: Brown, supra, 37, 43, 167-70.

43t See the schedule to the Bahamas Act, 40 Geo. 3, c. 2 listing English Acts in force. The text of the Act is reprinted in 1 J. Comp. Leg. (N.S.) 296.

4:s See volume 3 of the Revised Statutes of Ontario, 1897. This reprinted some Imperial statutes in force proprio vigore (at $x \times i-\mathbf{x x x y}$ ) and a few other fundamental statutes of constitutional importance received in Ontario (at vii-ix, xxxvi-xlii), and gave a table of other Imperial statutes in force proprio vigore (at xliii-xlv). Then the legislature reenacted parts of various English statutes probably received in Ontario as Ontario statutes. Among them were Magna Carta, the Statute of Monopolies, various procedural statutes, Gaming Acts, De Donis, the Statute of Uses, and so forth. These were grouped according to subject matter, and formed chapters 322 to 342 of the Revised Statutes of Ontario, 1897.

Though nominally part of the Revised Statutes of Ontario 1897, this was not done until 1902. The Ontario statute 2 Ed. 7, c. 13 repealed all English statutes consolidated in the Revised Statutes of Ontario 1897, and other English statutes were repealed by the (Ontario) Statute Law Revision Act 1902, and the Mortmain and Charitable Uses Act 1902. The combined effect of these three sets of repeals was summarized in Schedule A of the Revised Statutes (volume 3 at 3899-3902). Then Schedule B (at 3903-3913) showed where each old English Act had been reenacted in the Ontario statutes.

Schedule C (at 3914) mentioned eight English Acts and Acts on other subjects, which were probably in force, but not repealed or re-enacted, very likely because they were thought not to be within the legislative competence of the provincial legislature. The limitation is of course one which weakens the whole scheme, for there are possibly also such federal aspects to the matters dealt with by repeal and re-enactment.

It is to be noted that there was no general residual repeal of unnamed English statutes. 
may be found in Elizabeth G. Brown's two articles in (1963) 7 Am. J. Leg. Hist. 95, and (1963) 24 U. Pitt. L. Rev. 503, respectively. The United States of America is covered in part by her book British Statutes in American Law, 1776-1836 (1964), and in brief form by C.J.S. and Am. Jur. 2d.

It is therefore with some trepidation that yet another account of the reception of English law in the Canadian provinces is offered. A slight difference in emphasis together with some details not found elsewhere is the reason for this seeming duplication of effort.

\section{Newfoundland}

This was of course a settled colony, and indeed had some claim to be the oldest English colony. There were French rights in the area, most of which were ceded to Britain by treaty, but they have left no trace on the law of the area. Settlement was for years forbidden, and the date of settlement is not easy to discover. This happily has no importance though, for the courts have always held that English law was received as of 31 December 1832, the day before the holding of the first legislative assembly: see the judgment of Chief Justice Forbes in Yonge v. Blaikie (1822) 1 Nfld. L.R. 277 at 283. In 1792 the Imperial statute 32 Geo. 3 c. 46 , providing for the institution of courts in the colony, had said that they were to follow English law, but as no cut-off date was given, this was not of much importance.

English criminal law from time to time had been introduced by 1872 Const. Stats. titl. 12 c. 39 s. 1, but when the Canadian Criminal Code was introduced in 1950, this provision's successors were repealed by 14 Geo. 6 , c. 12, Schedule, (Can.).

One must of course remember that Newfoundland comprises not only the island of that name, but also Labrador on the adjoining mainland; the two territories were united by the Imperial statute 51 Geo. 3, c. 45 .

\section{Nova Scotia}

The bulk of this territory was originally settled by France, and later ceded to Britain, but the area has always been considered to be a settled colony: see for instance the preamble to the local Act 33 Geo. 2, c. 3, and the leading case on the reception of English law in the area, Uniacke v. Dickson (1848) 2 N.S.R. 287 (but cf. the dictum of the Chief Justice in Re Provincial Fisheries (1896) 26 S.C.R. 444 at 530). The cut-off date for English law has been said to be 3 October 1758, the date on which the first legislative assembly met: Falconbridge, Banking and Bills of Exchange 11 (6th ed.), though Lefroy, Short Treatise on the Canadian Constitution 52, thinks the date should be 1784, when New Brunswick was split off. And there is judicial authority for the year 1660: Scott v. Scott (1970) 15 D.L.R. (3d) 374 (N.B.C.A.).

Cape Breton Island was for a time a separate colony, but it was annexed and the general law of Nova Scotia extended to it by $1 \& 2$ Geo. 4, c. 5 (N.S.). See also Re Cape Breton Is. (1846) 5 Moo. P.C. 259, 13 E.R. 489.

\section{New Brunswick}

This was part of Nova Scotia until it was split off to form a separate colony by 31 Geo. 3 c. 2 (Imp.), which repealed any Nova Scotia statutes in force, but did not otherwise change the reception date of 3 October 1758. The statute of 31 Geo. 3 has been carried forward through New Brunswick statutes and now forms R.S.N.B. 1927, c. 1, s. 3. 


\section{Prince Edward Island}

This was also a part of Nova Scotia until separated in 1769 or 1770 , apparently by the commission of Governor Patterson dated August 4, 1769: Kelly v. Sullivan (1876) 1 S.C.R. 3 at 17. He arrived in the new colony in 1770. English law has been held to have been introduced as of 7 October 1763 by the general Royal proclamation introducing English law into all the former French possessions in North America which had been captured by Britain. This is interesting, for there is some doubt as to whether this same proclamation was intended to introduce English law into Quebec, as we shall see below.

\section{Quebec}

This was of course a French colony until the cession of 1759 and formal treaty of 1763 . English law was apparently introduced by the above-mentioned proclamation of 1763 (though there is doubt on this point: Coupland, The Quebec Act 31-32 (1925) and Wilcox v. Wilcox (1857) 2 L.C. Jur. 1 and Appendix; and Stuart v. Bowman (1851) 2 L.C.R. 369 and 2 L.C. Jur. Appendix at xii). This was radically altered by the Quebec Act of 1774, 14 Geo. 3, c. 83. That Act reintroduced the law of "Canada" (i.e. the old French law previously in force) for matters of "property and civil rights" but expressly preserved English criminal and testamentary laws.

In 1898 and 1912, the boundaries of the province were considerably enlarged, and apparently the general law of Quebec was introduced thereby into the territories so annexed. This was important, for most of the territory thereby added had originally belonged to the Hudson's Bay Company, and the Quebec Act expressly did not extend to that territory. As we shall see below under Manitoba, that territory had very different laws.

\section{Ontario}

In 1791 the Constitutional (or Canada) Act, (Imp.) 31 Geo. 3, c. 31 split off from the colony of Canada the newly-settled English-speaking areas west of the Ottawa River and constituted them as Upper Canada, a separate colony with its own legislature. That body by (U.C.) 32 Geo. 3, c. 1 immediately repealed "Canadian" law and introduced English law "from and after the passing of this Act." D. A. MacRae's book, Constitutional $L a w$, at 59 points out that at common law an Act took effect from the beginning of the session at which it was passed, which was September 15, 1792 in this case. It was not until 1793 (in England) that commencement dated from the date of Royal assent as a general rule (33 Geo. 3, c. 13). However, the wording here seems to suggest that the local Act was intended to take effect from the date of assent, which was October 15, 1792. In any event, later re-enactments have given October 15, 1792 as the date.

This 1792 Act established English law (excepting bankruptcy and poor laws, but including the law of evidence) as the rule of decision for all matters of "property and civil rights". This phrase was undoubtedly chosen because it had been used in the Quebec Act. Therefore, if one accepts the view that the 1763 proclamation had introduced English law, 32 Geo. 3, c. 1 removed from Upper Canada any French law which the Quebec Act had restored. If the 1763 proclamation introduced no English law then there is a gap for property and civil rights and criminal law do not exhaust the categories of law; topics not covered would then 
presumably still be covered by the old French law (except possibly for the parts of modern Ontario which were never parts of New France). This is a theoretical possibility universally disregarded in practice though. Everyone assumes that Ontario has received English law for all purposes.

A local Act (U.C.) 40 Geo. 3, c. 1 introduced English criminal law, but this was unnecessary, as the Quebec Act had already done that. Therefore, the only result was to move the cut-off date from 1763 or 1774 to September 17, 1792.

The Act (U.C.) 32 Geo. 3, c. 1 introducing English law as to property and civil rights has been re-enacted a number of times and is now R.S.O. 1970 , c. 367 , whose interpretation is discussed above. It chooses as the correct date October 15, 1792. Ontario has re-enacted a number of English statutes as local Acts, details of which are given above.

Ontario's borders were also considerably extended in 1889 and 1912, and the law applicable in these new areas is discussed in Vamuakadis $\mathrm{v}$. Kirkoff (1929) 64 O.L.R. 585 at 588-89, and supra, p. 52.

The English law of divorce and matrimonial causes as of July 15, 1870 was introduced by what is now R.S.C. 1952 , c. 85 . The statutes of jeofails, of limitations, accumulations, and "for the amendment of the law" up to January 17,1822 were introduced by R.S.O. 1897, c. 111, ss. 2, 3. How much this latter provision was intended to introduce is difficult to determine, but it does not matter, for in 1910 (Ont.) 10 Ed. 7, c. 45 repealed these provisions and in effect reverted to the 1792 Act.

\section{Manitoba}

All the territory draining into Hudson Bay ("Rupert's Land") was granted on May 2, 1670 to the Hudson's Bay Company by Charles II, and the charter provided that the law of England was to apply in this territory, presumably as of the date of the charter. See Oliver, The Canadian North-West at 75-76, 144-45, 149 (1914) or page 16 of the version in the Canadian Archives' Pioneer Legislation. Even if this charter could not have had legislative effect, it can probably have been considered as the settlement of a colony as of that date as the Company proceeded to establish trading posts in the following years.

French fur traders did much the same, but the possibility that any part of this territory could be thought of as a conquered colony has been largely ignored: see the authorities cited in (1964) 3 Alta. L. Rev. 263 n. 8, but $c f$. (1890) 1 Western L.T. 49 at 56, and the dictum of the Chief Justice in Re Provincial Fisheries (1896) 26 S.C.R. 444 at 530.

The Imperial Act 6 Geo. 3, c. 18 (Public General Acts at 325-26) provided for trial of offences in areas not within any British colony in the nearest British province according to the law of the place of trial. That provision was carried forward by 9 Geo. 3, c. 18,15 Geo. 3, c. 16, ss. 29 and 30 , and 16 Geo. 3 , c. 11 , but then seems to have lapsed until a similar provision was enacted by 43 Geo. 3 , c. 138 , which was declared by $1 \& 2$ Geo. 4, c. 66, s. 5 to extend also to Hudson's Bay Company territory. These Acts might well be thought to have made the laws of Upper Canada apply to the interior of British North America, at least as a matter of practical effect.

The Hudson's Bay Company became a little more active in its colony of Assiniboia (a small portion of Rupert's Land) in the 19th century. Their local legislative council in 1862 introduced the law of England as of 20 June 1837, and then on 7 January 1864 introduced later English law, 
though it is not clear whether it was introduced as of that date or as it might exist in England from time to time. See R.S.M. 1881, 1xxxix. It has been suggested that these ordinances were not intended to have more than procedural effect, nor was the territory in which they were intended to apply very clear. See the articles in the Western Law Times cited above as to this and the authorities cited in (1964) 3 Alta. L. Rev. 263 n. 11.

It is not surprising therefore, that the courts found the law of the area muddled. After the south-eastern part of Rupert's Land had become the Canadian province of Manitoba the local legislature cleared up the confusion by enacting 38 Vict., c. 12, declaring English law as of 15 July 1870 to be and to have been in force in Manitoba. The phrase "property and civil rights" was used, being clearly copied from the Ontario legislation on the subject, though we noted before that the choice of words is unfortunate. Shortly after this, someone must have realized that this would only cover matters within provincial constitutional competence and so the Dominion Parliament passed 51 Vict., c. 33, s. 1 to like effect. These two statutes have been carried forward since, and now constitute R.S.M. 1970, c. C-280, s. 51(3), and R.S.C. 1927, c. 124, s. 4 (the latter still being in force). It is unfortunate also that though Manitoba has twice since had her borders extended, it is by no means clear when or how the law of Manitoba was extended to these areas carved out of the Northwest Territories. But as we shall see, the practical difference is small, so far as English law is concerned, for the reception date was the same in those territories (cf. (Can.) 1881, c. 14, s. 3).

\section{The Northwest Territories}

Most of the interior of British North America between the Rocky Mountains and Upper Canada was occupied by Rupert's Land, whose history up to the middle of the nineteenth century is traced above under the first few paragraphs of Manitoba's history. The remainder of British territory (mostly to the north of Rupert's Land, plus a few scraps of other watersheds) was governed by (Imp.) $22 \& 23$ Vict., c. 26, providing for the trial of offences occuring in the area in British Columbia or Upper Canada. When Canada annexed Rupert's Land in 1870 so was the NorthWest Territory (now spelled as in the heading above), some parts of Canadian law were extended piecemeal.

Then (Can.) 49 Vict., c. 25, s. 3 extended English law as of $15 \mathrm{July} 1870$ to the area, to the extent it was applicable. This provision was shortly after re-enacted as R.S.C. 1886 , c. 50 , 8. 11 , and is now R.S.C. 1970 , c. N-22, 8. 18(1). The other British territories in North America had been annexed by Imperial Order in Council of 1880 and so automatically fell under these provisions.

\section{Yukon Territory}

This was split off the Northwest Territories, and when this was done the existing law was continued in force by (Can.) 61 Vict., c. 6, 8. 9, now R.S.C. 1970 , c. Y-2, s. 22(1).

\section{Saskatchewan}

When this area was in its turn separated from the rest of the Northwest Territories and constituted as a province in 1905, the Act (Can.) $4 \& 5 \mathrm{Ed}$. 7, c. 42 , 8. $16 \mathrm{kept}$ in force the prevailing law. 


\section{Alberta}

At the same time the adjoining territory was constituted the new province of Alberta, and 4 \& 5 Ed. 7, c. 3, s. 16 (Can.) also preserved the existing law. In 1908 the Supreme Court en banc pointed out that this in itself was a reception of another law (that of the Northwest Territories), and that strictly speaking one could not regard the old law as remaining in force of its own accord: Toll v. C.P.R. 8 W.L.R. 795 at 798-99; cf. Magnum v. McDougall [1944] 3 W.W.R. 486 (C.A.). And of course preconfederation law of other parts of Canada was never in force in Alberta: Walker v. A.-G. Alta. (1966) 60 D.L.R. (2d) 253 at 267 (C.A.).

The reception of English law on the Prairies, and especially in Alberta, is described in more detail in the author's article in (1964) 3 Alta. L. Rev. 262.

\section{British Columbia}

For a more detailed description of the reception of English law in this province see Professor Herbert's article in (1954) 2 U.B.C. Leg. N. 93.

This province is unique, for unlike other provinces, it is neither a captured colony nor a fragment of a settled territory; it alone is the product of the fusion of three settled colonies. Their separate histories are as follows:

\section{(a) The colony of Vancouver's Island}

We saw above that the Hudson's Bay Company was given all the land draining into Hudson Bay in 1670. In 1838, the Queen granted the Company exclusive trading privileges to the north and northwest of that area, in any territories not organized as British provinces or belonging to any other government (i.e. to the Czar of Russia or the United States of America). On January 13, 1849, the Queen gave the Company Vancouver's Island (now called Vancouver Island) on the condition that it be colonized. Then by the Imperial Act 12 \& 13 Vict., c. 48 on July 28, 1849, Parliament provided that the Acts of 43 George 3 and 2 George 4 (described above under Manitoba) should cease to apply, thus removing the jurisdiction of the courts of Upper Canada. This Act of 1849 went on to empower Her Majesty to establish courts and provide for their administration and to set up a legislature. And the Act annexed to the nascent colony all the adjacent British islands up to $52^{\circ}$ north latitude. Nothing was said about what law was to apply. On 3 April 1867, the Company reconveyed the territory to the Crown.

(b) British Columbia (the southern part of the mainland of the present-day province)

The Imperial statute $21 \& 22$ Vict., c. 99 established this colony and gave the Queen power to legislate for it. It also abrogated the old Acts of George 3 and George 4 to the extent that they applied to the Colony. The Queen exercised her legislative power by an Order in Council of 2 September 1858 by which she delegated her power of legislation to the Governor. On 19 November 1858, the Governor proclaimed the law of England as of that date to be in force in the Colony. Then in 1863 the Act (Imp.) 26 \& 27 Vict., c. 83 repealed the previous Act.

(c) Caledonia, or the Stickeen territories (the northern part of the mainland of the present-day province)

This was also a grant to the Hudson's Bay Company. By an Imperial 
Order in Council dated $19 \mathrm{July} 1862$, English law as of 1 January 1862 was declared in force in this territory, so far as applicable. The abovementioned $26 \& 27$ Vict., c. 83 in effect amalgamated this territory with the southern colony of British Columbia by extending the boundaries of the latter north to $60^{\circ}$ north latitude and east to the Rocky Mountains and $120^{\circ}$ west longitude. Whether this was intended to give the northerly areas the law of British Columbia (i.e. English law of 1858) is unclear.

(d) Union

Then the Imperial Act $29 \& 30$ Vict., c. 67 united the enlarged colony of British Columbia and the colony of Vancouver's Island as one new colony under the former name. By section 5 the existing laws were continued in force.

The existing legislature gained jurisdiction over the whole area, and by Act no. 7 of 1867 it extended English law as of 19 November 1858 to the entire territory. This Act has been re-enacted several times since, including (1871) 34 Vict., no. 70 and R.S.B.C. 1897, c. 115, and it now forms R.S.B.C. 1960 , c. 129.

When British Columbia joined Confederation in 1871, it lost its legislative power over many subjects, yet these provincial Acts purport to introduce English law as to all topics. Therefore, the post-Confederation Acts may be ultra vires in whole or part. But as there is no federal legislation on the subject (except possibly as to criminal law), presumably that means that the old pre-Confederation statute of 1867 is still in force in whole or in part. After all if the new Acts are invalid presumably their purported repeal of the 1867 Act would be similarly invalid. There is discussion of a very similar problem with respect to British Columbia's purported re-enactment of the English law on divorce in force in the province, in Hellens v. Densmore [1957] S.C.R. 768. 